
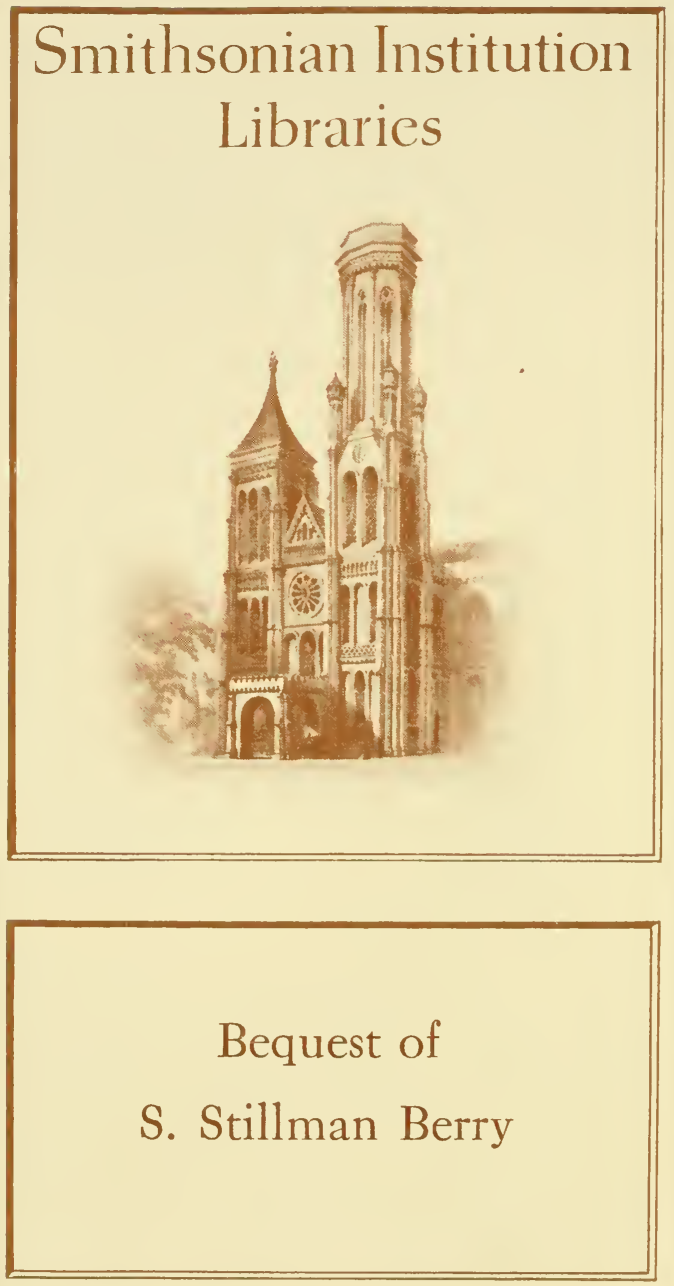

On this work see Jour.Conch. $22(6): 132,54452$ for nat on date 163i. 





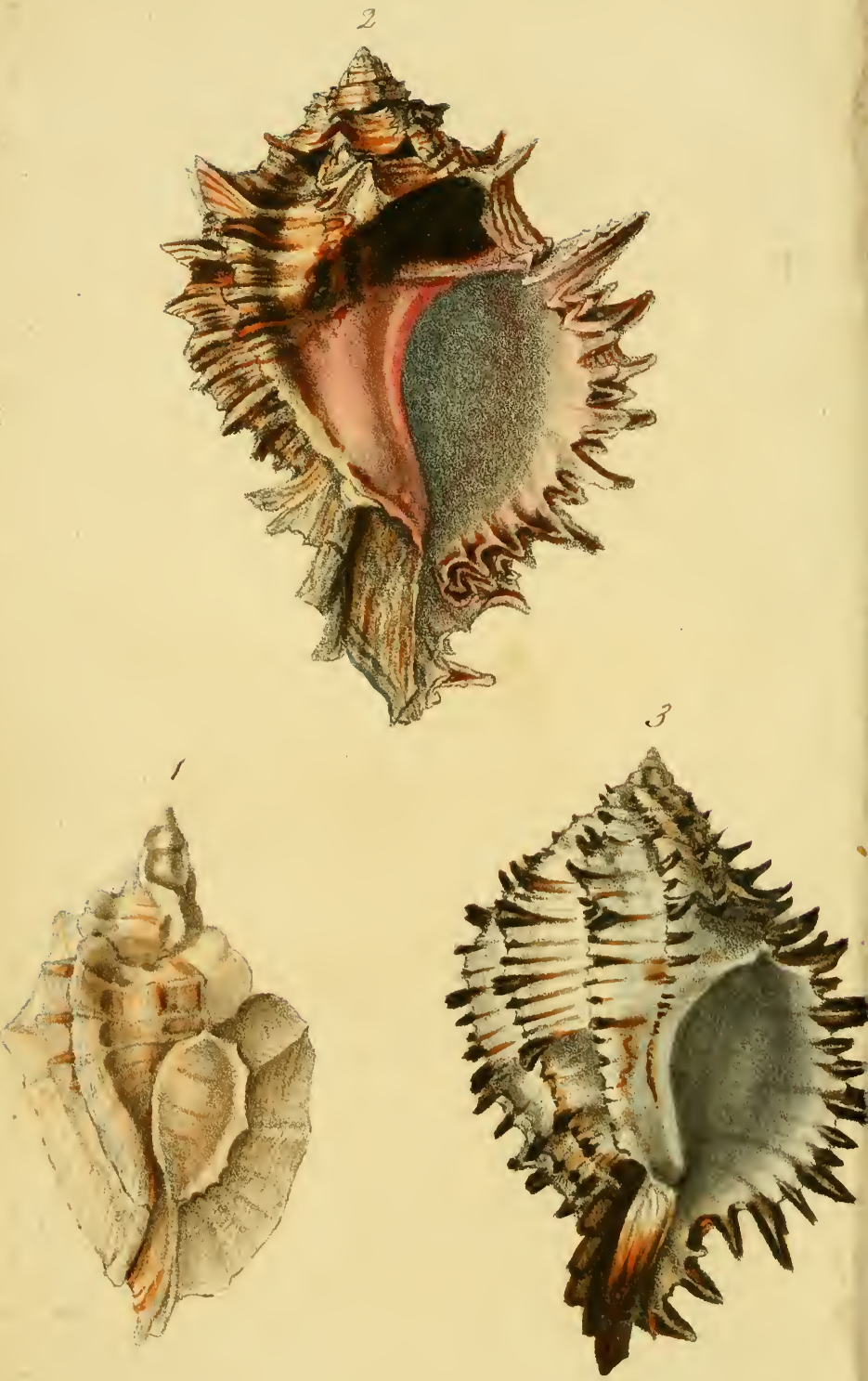


WODARCH'S

\title{
INTRODUCTION
}

To

\section{THE STUDY OF CONCHOLOGY:}

DESCRIBING

The Ororers, Genera, and Speries

\author{
OF \\ SHELLS :
}

WITH

OBSERVATIONS ON THE NATURE AND PROPERTIES

OF THE ANIMALS;

$\triangle N D$

DIRECTIONS FOR COLLECTING, PRESERVING, AND

CLEANING SHELLS.

BY

\section{J. MA WE,}

Author of Familiar Lessons on Mineralogy and Geology; Treatise on Diamonds and Precious Stunes; Travels in South America, and through the Gold and

Diamond Districts of Brazil, \&c. \&c.

FOURTH EDITION,

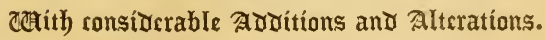

LONDON:

PUBLISHED BY LONGMAN, REES, ORME, BROWN, AND GREEN, PATERNOSTER ROW;

AND BY S. MAWE, 149, STRAND.

- 1831. 
LUNDON:

W. M'DOWALL, PRINTER, PEMEERTON ROW, GOUGII SRUARE. 


\section{PREFACE.}

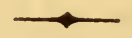

$\mathrm{I}_{\mathrm{T}}$ is a circumstance no less to be lamented than wondered at, that, in the present enlightened age, when the cultivation of science, and natural history in particular, is so eminently conspicuous, Conchology, or the natural history of shells, should have participated so sparingly of that active spirit of research and investigation, which has been so lavishly bestowed on almost all other branches.

ONE obvious reason, however, may be assigned, why Conchology has remained so long stationary in the lists of improvement. Till lately, no publications on shells have appeared, but such as were abstruse, voluminous, expensive, and difficult of access; and as most of them were in languages not always thoroughly understood, the attainment of knowledge through their means frequently became a source of difficulty and trouble.

IT is perhaps from this very circumstance, that many individuals who possess fine and rare shells, are totally ig- 
norant of any systematic mode of arranging them; the consequence is, they are suffered to remain in the cabinets like a collection of unknown gems, whose intrinsic value their proprietor being unacquainted with, they are incapable of affording amusement, information, or profit to him.

INFLUENCED by the repeated observation of the occurrence of these difficulties, it appeared desirable, that the public should be put in possession of some compendious or abridged treatise on Conchology, which would at once enable the young student to arrange his collection systematically, and at the same time tend to enhance the value of that science, which, for want of a proper key, or book of introduction, has remained too long in neglected obscurity.

To accomplish this, it appeared only necessary to select the choicest materials contained in more elaborate works, and arrange them in such order as would afford all the instruction requisite for the information and improvement of the young Conchologist, in a concentrated, perspicuous, and purchasable form.

IT has been made a point, throughout the work, to adhere rigidly to the Linnæan system, on the strong presumption, that it would always prove the surest basis on which a more modern superstructure might be raised. 
Bur, as other less celebrated naturalists have also contributed their quantum of information on the subject of Conchology, it has been thought prudent to add whatever they have urged of most importance; and as it is a matter of consequence for the learner to call in the aid of figures as well as description, it was thought proper to annex facsimiles of the most prominent species of the different genera of shells; and as they are from nature, the correctness of their delineation may be depended upon.

It was also deemed necessary, in order to render the work more generally useful and acceptable, to submit a concise account of the nature, habits, and uses of shell-fish; as weil as some serviceable hints and directions as to the best modes of collecting and cleaning shells.

CHARLES WODARCH. 



\title{
ADVERTISEMENT
}

To

THE FOLRTH EDITION.

\begin{abstract}
IN this Edition the new species recently discorered have been added; and a considerable alteration has been made in the arrangement of the species of each genus, with a view to afford greater facility to the student's acquiring a knowledge of their distinctive characters.
\end{abstract}

It would have been beyond the scope of an elementary work of this nature to have described every species; but we have endearoured, by forming numerous divisions and families, and affixing to each a concise description, so to class together the species, that the student will have little difficulty in assigning any shell that may present itself to his observation to its proper division and family; and should the shell have obtained a name descriptive of a leading character, he will have no difficulty in discovering it by referring to the lists of scientific and English or trivial names accompanying the genera. 



\section{FRONTISPIECE.}

Fig. 1. Murex Foliatus. Foliated Murex.

2. ...... Regius.. Royal Murex.

3. ..... Radix... Root or Black-spined Murex. 



\section{CONTENTS.}

Glossary........................... Page ,

\section{CHAPTER I.}

General Observations..................... g

Properties of animals inhabiting shells............ 10

Customary uses to which shells and their inhabitants are converted........................... 10

Enemies to shells and shell-fish $\ldots \ldots \ldots \ldots \ldots \ldots \ldots, 12$

Directions for collecting shells, and arranging them systematically............................ 14

Methods of preserving and cleaning shells .......... 15

CHAP'TER II.

Description of the animals inhabiting shells $\ldots . \ldots \ldots \ldots$ is

\section{CHAPTER III.}

Classification....................... 21

1. Multivalves ......................... 21

I1. Bivalves.......................... 21

III. Univalves, -1 . With a regular spire ........... 22

2. Without a regular spire......... 23 
ORDER I.-MULTIVALVES.

Chiton ............ 25 | Lepas ............ 28

Pholas.................32

\section{ORDER II.-BIVALVES.}

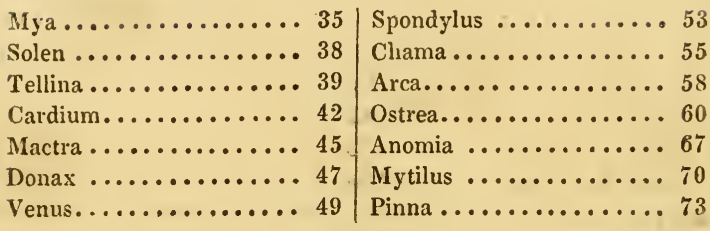

ORDER III.-UNIVALVES.

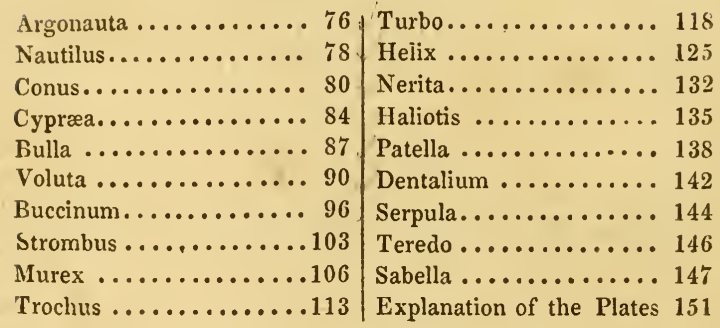




\section{GLOSSARY}

OF

'TERMS USED IN CONCHOLOGY.

Acuminated, terminated in a sharp point.

Anterior, (in Univalves) the part which forms the spire:

(in Bivalves), see Margin.

Aperture, the orifice or opening of the shell; it is called angular, when its circumference has several angles: $b i$ marginated, when the right lip forms a double margin: coarctate, contracted: compressed, flattened: gaping, when one of the extremities is wider than the other: linear, when narrow, and the length greatly exceeds the breadth: transverse, when the breadth is greater than the length. (These terms are applied to Univalves). Apex, the tip or small end of a shell.

Articulated, (applied to Multivalves), when the different pieces of which the shell is composed are so strongly united, that they appear to form one shell: (when applied to Bivalves), see Teeth.

Auriculated, having ears.

Base, (applied to Multivalves), the part on which the shell is supported: (to Univalves), the most elevated part of the shell, opposite to the spire.

Beak, Beaked, having the extremity of the base of the shell elongated and contracted in the form of a beak. 
Bearded, when the epidermis is of a bristly or hairy nature.

Bifid, forked.

Byssus, a hair-like substance formed by some of the animals of Bivalves, by which they attach themselves to extraneous bodies. See plate 6, fig. 1 .

Callous, indurated.

Callus, a thick excrescence.

Canal, the prolongation of the mouth in a kind of groove or gutter, as in the Murex and Strombus.

Canaliculated, channelled or grooved.

Cardinal, see Teeth.

Carinated, having the form of a boat's keel.

Cartilage, see Ligament.

Cartilaginous, resembling a ligament.

Chambered, when the shell is internally divided by partitions parallel to the aperture.

Ciliated, surrounded with parallel filaments.

Clavate, club-shaped.

Columeila, that part of the shell round which the whirls turn.

Compressed, (in Bivalves), when the valves are nearly flat, or flattened.

Concamerated, see Chambered.

Conrolute, when the whirls turn round a lengthened cone, nearly vertical to each other.

Cordiform, heart-shaped.

Coronated, having the apex surrounded with a row of tubercles or spines.

Crenated, Cremulate, having blunt teeth.

Decollated, having the spire or upper part of the shell truncated transversely.

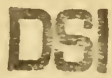


Decussated, intersected by striæ at acute angles.

Dentated, having teeth.

Diaphanous, transparent.

Digitated, having projecting claws.

Divaricated, obliquely striated.

Dorsal, belonging to the back.

Ears, external projections on the sides of the hinge, (see plate 6, fig. 5.)

Effuse, having the lip separated by a gutter.

Emarginate, having the margin excavated by a canal.

Epidermis, the outer skin or covering of a shell.

Equilateral, when the anterior and posterior parts of a shell are exactly similar.

Equivalve, (applied to Multivalves), when the two principal ralves have the same form, size, and position: (to Bivalves), when the two valves are exactly similar.

Exserted, very thin or slender.

Fissure, a notch or slit, (see plate 4, fig. 57.)

Furrou, a gutter or groove running parallel to the hinge in Bivalves.

Fusiform, spindle-shaped.

Gaping, (in Bivalves), when the valves do not shut close: (in Univalves), when the lower part of the lips is distended.

Gibbosity, a swelling.

Gibbous, swelled.

Glabrous, smooth.

Hinge, the part where the valves are united, and generally furnished with one or more teeth: it is said to be compressed, when it is formed of one compressed tooth: 
lateral, when placed on one side of the shell: reflected, when its edges are folded over the exterior margin : terminal, if situated at the extremity of the shell: and truncated, if the beaks of the shell appear to have been transversely cut off, and the teeth of the hinge fixed to this part.

Hispid, covered with hairs, as in the Helix hispida.

Imbricate, when the surface is covered with scales partially over-lapping each other.

Imperforate, having no umbilicus.

Inequilateral, when the anterior and posterior parts of the shell are dissimilar.

Inequivalve, when the valves are dissimilar.

Involute, without a spire, as in the Patellæ.

Keeled, see Carinated.

Labium, see Lip.

Lenticular, when the valves are round, and diminish in thickness from the centre towards the edges.

Lid, see Operculum.

Ligament, a membranous substance which connects the valves: it is both interior and exterior in the generality of Bivalves.

Linear, when the length of the shell is greater than its breadth, and its form not cylindrical.

Linguiform, tongue-shaped.

Lip, (in Univalves), the sides of the aperture: (in Bivalves), the exterior edge of the valves.

Lunar or Lunate, having a crescent form.

Margin, the edge of the shell: anterior, the space in which the ligament is situated; posterior, the space on the 
other side of the hinge; superior, the space between the anterior and posterior parts.

Marginate, (in Univalves), having the sides of the shell thickened: (in Bivalves), surrounded with an elevated margin.

Mouth, see Aperture.

Huscular impressions, are the marks made by the muscles with which the animal adheres to the shell, as in the common oyster.

Obovate, nearly oval.

Obsolete, obliterated.

Obtuse, blunt pointed.

Operculum, (in Multivalves), the stellular valves which shut up the superior orifice: (in Univalves), the part which exactly fits into the aperture, and incloses the animal.

Papillary, having the apex rounded.

Papyraceous, of the thinness of paper.

Patulous, gaping.

Pectinated, when the longitudinal ribs on the anterior surface form acute angles with the transverse striæ.

Peduncle, a tendinous substance belonging to some of the Multivalves, by means of which they adhere to solid bodies.

Pillar, see Columella.

Pillar-lip, that side of the aperture in which the columella is situated.

Pisiform, pea-like.

Plaited, when the columella is toothed, as in Volutes. Posterior, see Margin.

Reticulated, like net-work. 
Retuse, when the lower whirls are pressed into the body. Rostrum, see Beak.

Rugose, wrinkled.

Scabrous, rough.

Serrated, toothed like a saw.

Semilunar, like a half-moon.

Sessile, low, dwarf.

Sinuous, waved.

Sinus, a deep cut, as in the lip of the Murex Babylonius. Siphon, a prolonged tube rumning through the partitions of chambered shells.

Slope, the side from the beaks.

Spinous, having prickles or thorns.

Spire, is formed by the whole of the upper whirls.

Stria, lines flat, or slightly raised: they are called longitudinal, when they run from hinge to margin; transverse, when in a contrary direction; and concentric, when they form segments of circles.

Subcordate, approaching the form of a heart.

Subpellucid, not quite clear.

Subulate, tapering.

Superior, see Margin.

Suture, a toothed joint.

Teeth, (in Univalves), angular plaits, as on the pillar lip of Volutes: (in Bivalves), pointed protuberances within the hinge, by which the valves are united. They are called: alternate, when the teeth of one valve are received between the teeth of the other valve; articulated, when the tooth is received into a corresponding cavity in the opposite valve; cardinal, the central tooth or teeth of the hinge; compressed, when flattened; erect, perpendicular to the plane of the hinge; forked, having 
the point divided into two; longitudinal, when it extends along the margin.

Tubercle, a protuberance or kncb.

Tuberculated, having elevations resembling warts.

Tubular, (applied to Multivalves), when the greater part of the shell is cylindrical.

Turbinuted, when the belly of the shell is large in proportion to the spire, which seems to proceed from the centre.

Valves, the different pieces which compose the shell.

Varix, Varices, longitudinal elevations or ribs, formed by the junction of the different additions the shell has received.

Ventricose, swollen.

Vermiform, having the form of worms.

lertex, the top or point of a shell.

Umbilicated, having a hole in the base of the pillar.

Umbo, the summit.

Undulated, waved.

Whirl, a spiral convolution. 



\section{INTRODUC'TION.}

\section{CHAP'TER I.}

\section{GENERAL OBSERVATIONS.}

'THE division or branch of natural history on which this work treats, is called Conchology; it comprehends the study and history of testaceous animals, and not only includes those of the sea, but also those of rivers and of the land.

Testaceous animals are such as have a calcareous covering or habitation, in which the animal, otherwise naked or fleshy, lives included and protected.

All animals inhabiting shells are exsanguinous, and destitute of bones; but they are endowed with a heart, lungs, mouth, and other organs adapted to their nature.

It is perhaps necessary to prepare the young Conchologist with the knowledge, that all shells, in their various stages of growth, assume very different appearances; in the younger, the shell is usually fragile, thin, and semitransparent, and generally unprovided with the ribs, tubercles, ramifications, and denticulations, which are manifest in those of maturer growth; the adults, however, as they advance in age, become thick and ponderous; their surface also becomes covered with callosities; and they lose that brilliancy of external colouring and marking which had characterized their earlier state. But although these 
differences, in some instances, are sufficient to excite a considerable degree of perplexity, yet there is always in every shell a definite character, by which the Conchologist will be able to distinguish its genus and species; for each genus or species is characterized by structure, substance, marks, or colour, which the shells of that genus or species almost invariably retain in all their stages of growth and varieties of form, and consequently are thereby easily known and distinguished.

\section{PROPERTIES OF ANIMALS INHABITING SHELLS.}

These animals possess the power of extending or aggrandizing their calcareous habitation or shell, and are also enabled to repair whatever breaches their brittle dwellings may have sustained by the turbulence of the ocean. The operation of enlarging and repairing the shell is supposed to be effected by a peculiar endowment of the animal, which can at pleasure discharge a viscous humour, that soon becomes hardened or consolidated, and in time acquires the consistence of the rest of the shell.

Many shells are covered with a cutaneous or skin-like substance, called the epidermis, which serves to protect the heautiful colors and markings which are frequently concealed beneath it.

CUSTOMARY USES TO WHICH SHELLS AND THEIR INHABITANTS ARE CONVERTED.

THE principal benefit derived by man from shell-fish appears to be in the way of food. Whole countries are 
known to have no other sustenance, for weeks together, but the produce of the sea; and shell-fish fill no unimportant station in the immense catalogue of its inhabitants.

The nutritive and delicious food afforded by oysters, scallops, muscles, and cockles, is too well known to require any remark.

In many countries which do not produce limestone, as the coast of Brazil, \&c., shells are collected in great quantities, and, after calcination, form a most desirable substitute for that useful substance: in this state they are also considered excellent as manure.

The Indians frequently convert shells into domestic and defensive implements; the South-sea islanders, for example, head their javelins with them, and manufacture them into fish hooks and various sorts of tools. Their principal ornaments are often studded or embossed with rows and groups of shells, artfully disposed, in regular order, which are worn as marks of superiority, or as bracelets or armlets, and frequently form handsome appendages for the ears. A very extensive commerce is carried on in Ceylon with the shank shell, (Murex rapa), which is in great request for ornamental purposes.

The Chinese convert shells, that are opalescent when uncoated, into various articles of domestic economy, suclı as drinking cups, ewers, \&c.; and the Indian cabinets, so much admired for their beauty and exquisite workmanlip, are principally composed of iridescent shells, judiciously inlaid and blended with tortoise-shell and other substances.

Some species of the oyster and muscle genera are celebrated for the production of pearls, the value and beauty of which can perhaps be best estimated by those who are in the habit of purchasing and wearing them.

There is one large species of Murex, called M. tritonis, 
which, after having had the apex, or extreme tip, broken off, becomes an excellent substitute for a trumpet or horn, and is frequently used by the New Zealanders for that purpose.

The famous Tyrian dye, so celebrated by the antients for the luxuriant purple colour it imparted to the robes of royalty, is an extract from a shell-fish of the genus Murex, and commonly known under the appellation of the Purpura or purple fish. An account of the method of using it in marking linen, \&c. is given by Mr. Mawe, in his Travels though the Gold and Diamond Districts of Brazil, 2nd edit. p. 70.

\section{ENEMIES TO SHELLS AND SHELL-FISH.}

Iт appears that shell-fish, besides affording food for man, are destined to supply other creatures also with nourishment. It is said that monkies are particularly fond of most species of bivalves, and that the mode they take to catch them is as follows:-At low water, the monkey repairs to the shore, and searches for oysters and muscles left by the tide; the fish, for want of water, generally have their valves partly open; the subtle animal, foreseeing the danger of trusting his paws between the shells, artfully drops a stone or two into them, which entirely prevents their being closed by the fish; by this expedient he is enabled to extract his prey without danger or difficulty, and devour it at his pleasure.

Tortoises and turtles consume numbers of shell-fish, and the strength of their jaws (as reported) is so great, that they can with facility masticate the strongest and roughest shells.

Birds also, (sea-fowl especially), are great devourers of 
shell-fish; and when they are unable to penetrate the shells with their beaks, they ascend with them to a considerable height, and let them fall on some rough or craggy place; by which means the shells are broken, and the fish becomes an easy victim*.

Crabs, and other crustaceous animals, are known to make serious attacks on the testaceous orders. The larger sort of crabs are able, by their great strength, to open the valves of most shells by main force; but those of smaller dimensions make their inroads in a different manner: the pea-crab, in particular, is very destructive to bivalves, especially to muscles; it enters their shells whenever it has the opportunity of finding them open, and there remains, preying upon the fish, till it has entirely consumed it; at which period the shell opens, the crab takes his departure, and proceeds to make similar attacks elsewhere.

Another species, called the hermit crab, is also supposed to be implicated in similar offensive operations among univalves; for it is frequently found housed in the vacant habitation of a buccinum, turbo, or nerite, and is therefore suspected of having previously devoured the animal, and afterwards to have secured a retreat for itself in the empty shell.

* Mr. Mawe states, in his Travels in Brazil, that he saw a spot of bare granite, not more than one hundred yards square, covered with an immense number of mutilated shells; the whole neighbourhood was rich in wood and verdure, and the sea at least five miles distant. On inquiry he was informed, that large flocks of birds every evening repaired to this place with shells left by the tide, which they let fall on the rock, in order to ob. tain their contents. 
The serpulæ, balani, chamæ, and anomiæ, often affix themselves in clusters to the shells of other genera; and although they destroy the beauty and symmetry of the shell, they very rarely injure its inhabitant.

Shell-fish, though they in part constitute the food of animals, birds, and fish, yet, in their turn, have some opportunity of retaliation, by partially destroying the floating habitation of the universal despoiler, Man; the Pholas and Teredo navalis, in particular, frequently commit such serious injury on ships, by boring into their planks, as often to endanger the safety of the ressel, if not speedily prevented in their operations.

FIRECTIONS FOR COLLECTING SHELLS, AND ARRANGING THEM SYSTEMATICALLY.

W гти regard to collecting shells, it is necessary to hint to those students, who, by a residence on the sea coast, may have an opportunity of forming collections for themselves, that the best way is to select the shells which have the animals alive in them; for those that are found empty on the beach are for the most part objectionable, the shell becoming impaired by the co-operation of the sun and waters, which also greatly tends to destroy the beauty of the colouring and marking.

Besides, a double advantage is to be derived fiom having the animals alive, for, by keeping them in sea water, much useful information may be obtained by an accurate observation of their structure and habits.

Storms frequently drive up live shells on the beach: such should be collected as soon as possible, as they fre- 
quently lose their delicate spines and foliations, by being suffered to remain beating about on the shore.

As land and river shells are seldom so beautifully formed, marked, or colored, as those of the ocean, they are in consequence rarely so much prized; however, they form an interesting part in all collections.

The collector should always keep the following objects in view, whenever he commences the arrangement of his shells:-

First. The order to which they belong, that is, whether they are to be classed with the Multivalves, (i.e. shells of many valers); Bivalves, (shells of two valves); or Univalves, (shells of one part of piece only) : which three grand divisions constitute the leading distinctions of shells.

Secondly. He should be careful to place them in the proper genus of the order to which they belong.-And,

Thirdly. He should avoid misplacing or confusing the species which appertain to each genus. And if, in the course of his studies, he should be fortunate enough to obtain any hitherto undiscovered genus, species, or variety, he should make such an accurate description and drawing, as would, by submitting them to the opinion and judgment of the scientific, confirm him in the correctness of his own conclusions, and tend to promote the general advancement of conchological knowledge.

THE METHODS OF PRESERVING AND CLEANING SHELLS.

If the shell contains the animal alive, it will be necessary to immerse it in boiling water for a few minutes; then plunge it into cold water, which will cause the ani- 
mal to contract, and render it more easy to be extracted: crooked pins, and other sharp instruments, are sometimes required to effect a perfect extraction.

If a large quantity of shells is to be cleaned, dissolve half a pound of potash, and half a pound of soft soap, in two quarts of boiling water; stir the solution until all the particles are dissolved, and then pour it warm over the shells; let them remain in this liquid two or three days, frequently warming it, and pouring it over them. After this process, wash them well with a brush in warm water; and, when dry, rub them with a nail brush, until they have received a sufficient polish. This method may be adopted with all smooth shells, such as olives, cowries, cones, \&c.

Rugged shells generally require a different process from the preceding, though it is advisable to try that method first. But if they are covered with adhesions, or the epidermis will not separate from the shell, it is also necessary to use muriatic acid, after they have undergone the abovementioned process. When they are perfectly dry, the acid is to be applied with a fine brush, dipped in sand, to the parts which require it. After the adhesions, \&rc., are removed, the shell must be immediately immersed in alkali, to neutralize the effects of the acid, and then well washed in warm water. As these shells are not susceptible of so fine a polish as the smoother varieties, it is usual to give them an artificial gloss, by brushing them over with a weak solution of gum-arabic.

Corals, which are so justly admired for their delicate structure, elegant ramifications, and great beauty, may be cleaned in a similar manner, by steeping them a few days in the solution of potash and soft soap; after which they should be carefully brushed in warm water. 
It not unfrequently happens that corals are discolored by some extraneous substance; when this is the case, the part discolored must be immersed in a weak solution of muriatic acid, until the outer surface is removed, and then dipped in alkali, to neutralize the effects of the acid. They must afterwards be cleaned by repeated ablutions in warm water. 


\section{CHAPTER II.}

OF these animals a minute and accurate anatomical description is not to be expected; for little more is known of their structure than what has been given by naturalists concerning their external characters.

Some of the animals which inhabit shells are also found in the mollusca state, that is, without any testaceous covering. Such, for instance, is the Limax, or slug.

The animals which have been described as inhabiting shells are the following; viz. Doris, Triton, Ascidia, Tethys, Limax, Spio, Amphitrite, Terebella, Nereis, Sepia, and Clio.

Doris.-The body is creeping, oblong, and flat beneath; the mouth is placed below on the fore part; vent behind on the back, and surrounded by a fringe. Feelers two or four, situated on the upper part of the body in front, and retractile within the proper receptacles. - The animal which inhabits the Chiton belongs to this genus.

Triton.-The body is oblong, and the mouth is furnished with an involute spiral proboscis; tentacula or arms twelve, six on each side, divided nearly to the base. The hinder ones cheliferous. - The Triton inhabits different species of Lepas.

Ascidia.-The body is fixed, roundish, and apparently issuing from a sheath; apertures two, generally placed near the upper end, one beneath the other. The animals are found in the sea, and adhere by their base to rocks, 
shells, and other submarine substances: they are more or less gelatinous. The only powers of motion which they possess seem to be that of contracting and dilating themselves alternately; by which means they are enabled to eject, with considerable force, the water which they imbibe.-This animal inhabits the Pholas, Solen, some species of the Mya, Mactra, and other bivalves.

Tethys.-The body is detached, rather oblong, fleshy, without peduncles: the mouth is furnished with a terminal cylindrical proboscis, under an expanded membrane or lip; apertures two, on the left side of the neck.-The Tethys inhabits a great proportion of bivalve shells, as, many species of Tellina, Cardium, Mactra, Venus, Ostrea, and others.

Limax.-The body is oblong, creeping, with a fleshy kind of shield above, and a longitudinal flat disc beneath : aperture placed on the right side within the shield: feelers four, situated above the mouth, with an eye at the top of each of the larger ones.-The animals belonging to this genus inhabit the turbinated univalve shells; but it appears that all the animals which inhabit these shells do not exactly correspond with the above generic characters.

Spio.-The body projecting from a tube, jointed and furnished with dorsal fibres; peduncles or feet rough with bristles, and placed towards the back; feelers two, long, simple; eyes two, long.-This animal inhabits some species of Sabella.

Amphitrite.-Body projecting from a tube, and annulate; peduncles or feet small, numerous, with lateral fasciculi, and branchiæ; feelers two, approximate, feathered; no eyes.-The Amphitrite inhabits some species of Sabella and Serpula.

Terebella.-Body oblong, creeping, naked, furnished with lateral fasciculi or tufts, and branchiæ; mouth placed 
before, furnished with lips, without teeth, and protruding a clavated proboscis; feelers numerous, ciliated, capillary, and placed round the mouth.-This animal is an inhabitant of many species of Dentalium, Serpula, and Sabella.

Nereis.-Body long, creeping, with numerous lateral peduncles or feet on each side; feelers simple, rarely none; eyes two or four, rarely none--According to some naturalists, the Nereis inhabits some species of Sabella.

Clio.-Body oblong, natant, generally sheathed, and furnished with two dilated membranaceous arms or winglike processes; tentacula three, besides two in the mouth. According to some naturalists, the animal which inhabits the Argonauta belongs to this genus. 
INTRODUCTION.

CHAPTER III.

CLASSIFICATION OF SHELLS.

LINN EUS ranks Testacea as the third order in his sixth class of animals called Worms. He has made three principal or grand divisions, viz. Multivalves, Bivalves, and Univalves.

\section{MULTIVALVES.}

SIELLS WITH MANY VALVES.

1. Chitos: Valves placed in transverse plaits down the back.

2. Lepas: Valves unequal; body sessile, or on peduncies.

3. Pholas: Shell bivalve, with accessory valves at the hinge.

\section{BIVALVES.}

SHELLS WITH TWO VALVES.

4. MYA: Hinge with generally a broad thick tooth, not let into the opposite valve.

5. Solen: Shell open at each end; hinge with a single or double subulate reflected tooth, not let into the opposite valve.

6. Tellina: Hinge with the lateral teeth of one valve not let into the other. 
7. CARDIUM: Hinge with remote penetrating lateral teeth.

8. Mactra: Hinge with a complicated triangular middle tooth, and an adjoining hollow.

9. Donax: Hinge with a generally remote lateral tooth, not let into the opposite valve.

10. Venus: Hinge with generally three approximate divaricate teetl.

11. Spondyus: Hinge with two teeth, separated by a small hollow.

12. Chava: Hinge in one shell, with two oblique obtuse teeth.

13. Arca: Hinge with numerous penetrating teeth.

14. Ostrea: Hinge without teeth, but an ovate hollow.

15. Axомia: Hinge without teeth, but generally a linear depression on the rim, the beak of one valve curved over the hinge.

16. Mrtilus: Hinge without teeth, with a subulate depression, and generally fixed by a silky beard.

17. Prnna: Hinge without teeth, valves united at one end, and open at the other.

\section{UNIVALVES.}

1. With A REgUlar SPIRE.

18. Argonauta: Shell with one cell, spiral, involute.

19. Nautilus: Shell with many cells, with a siphon of communication.

20. Conus: Aperture effuse, longitudinal, without teeth.

21. Cyprea : A perture effuse, lineal, longitudinal, toothed on each side.

22. Bulla: Aperture a little contracted, and placed obliquely; toothed on one side only. 
23. Voluta: Aperture effuse, the pillar plaited.

24. Buccinum: Aperture with a small canal leaning to the right.

25. Strombus. Aperture with a small canal leaning to the left.

26. Murex: Aperture with a small straight canal.

27. Tкоснus: Aperture contracted, and somewhat triangular.

28. Turbo: Aperture contracted and orbicular.

29. Helix: Aperture contracted, lunate on the inner side.

30. Nerita: A perture contracted, and semiorbicular.

31. HaLıтіs: Shell ear-shaped, aperture dilated, with a row of orifices along the surface.

2. WITHOUT A REGULAR SPIRE.

32. Patella: Shell conic, the aperture widened like a basin.

33. Dentalium: Shell slender, subulate, open at both ends. 34. Serpula: Shell tubular, mostly serpentine, adhering to other bodies.

35. Teredo: Shell thin, penetrating wood.

36. Sabella: Shell composed of agglutinated grains of sand, \&c. 



\section{INTRODUCTION}

\section{To \\ C O N C H O L O G Y.}

\section{ORDER I.}

MULTIVALVES.

CHITON.-Coat of Mail.

Animal inhabiting the shell-a Doris: Shell consisting of several segments of valves disposed down the back.

'THE genus Chiton ranks first in the classification of Testacea, or shells; and no less than fifty-two species are described, some of which are exceedingly beautiful and uncommon. It is almost impossible to confuse this genus with any other of the shell tribe, for all its species and varieties coincide so nearly in their general formation and attributes, that the situation in which they ought to be placed may at once be decided upon.

The most distinguishing character of the Chiton is that of bearing a strong resemblance to a small vessel or boat, high built at the stern, and turned upside down; and this 
peculiar form is constituted by the attachment of eight moveable valves, which are connected by a cutaneous or cartilaginous substance, capable of sufficient distention and contraction, to admit of considerable action or play on the part of the valves; so much so, that the animal can at pleasure convert its shell into the form of a ball, and thereby assume the appearance of a little insect, well known as an inhabitant of old and decayed wood.

The covering and colouring of the valves serve to create distinction; some being perfectly smooth, others nodulous, or knobbed; some beset with spines, prickles, or hairs; and others, again, are striated, dotted, and rayed, as the C. hispidus, C. squamosus, and C. marmoratus.

The colour of the exterior is frequently a dusky brown, often passing into different shades of olive-green: others partake of a reddish or pinkish tint; whereas some specimens are of an ochreous or yellowish-white complexion; and many have their valves adorned with elegant designs and marblings (not unlike tattooing) in the liveliest colours imaginable.

The interior also admits of much variation with regard to colour; howerer, the most prevalent is that of a blueishwhite, often beautifully diversified with cloudings of yellow, brown, light green, and pink.

The margin which confines the valves in their proper situations, differs materially in the various species: in some instances, it is smooth and of a yellowish-brown colour; generally, however, it is beset with fine scales, of a green or olive colour; frequently it is of a reddish tint, and in some species it is dusky-brown, or even black.

The situation and formation of the valves throughout the genus resemble the plates which constitute a suit of armour or coat of mail ; and it is from this marked similarity that the Chiton has derived its name. 
The habitat, or place of residence, of these shells seems to appertain, indiscriminately, to all parts of the globe.-America affords the most; the coast of Chili has recently furnished many very beautiful species which were previously unknown; several are from the East Indies; Africa supplies a few; and the Northern seas contribute their portion of the remainder.

The Chiton, like the limpet, is generally found adhering to rocks and other substances, as shells, stones, madrepores, corals, \&c., and some of the northern species fiequent the roots of sea weed.

The following is a list of the different species, taken from Gmelin's last edition of Linnæus's Systema Naturæ, with the addition of those species which have been discovered since the publication of that work. A similar list will follow the general description of each genus.-The species found on the British coasts are distinguished by an asterisk.

\section{CHITON-Coat of Mail.}

\section{Division I.-Having a scaly margin.}

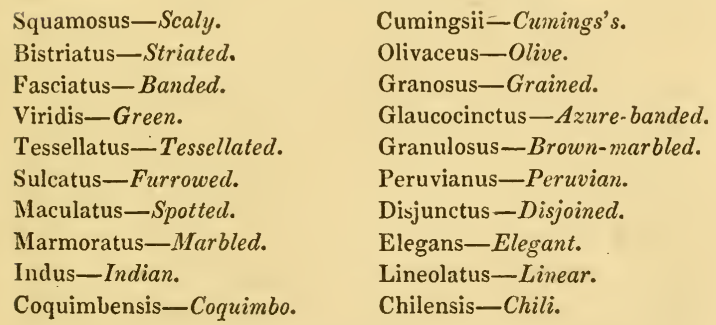

Division II.-Having a coriaceous margin.

Fulvus-Tawny.

Tunicatus-Coated.
Castaneus-Chesnut.

Lineatus-Striped. 
Aculeatus-Prickly.

* Fascicularis-Banded.

Punctatus-Dotted.

Ruber-Red.

Albus-White.

Cinereus-Ash-coloured.

Bicolor-Variegated.

Cerasinus-Cherry-coloured.

Magellanicus-Magellan.

Fuscus-Brown.

Granulatus-Granulated.

Piceus-Pitchy.

Minimus-Mealy.
Cimex-Bug-like.

Asellus-Millipede.

Gigas-Large.

Islandicus-Icelandic.

* Marginatus-Marginated.

*Lævis-Smiooth.

Amiculatus-Imbricated.

Tuberculatus-Knobbed.

*Crinitus-Hairy.

Thalassinus-Sea-green.

Hispidus-Bristly.

Porosus-Porous.

Larvæformis-Caterpillar.

Division III.-Haring a spinous margin.

Spinosus-Spiny.

Spiniferus-Thorny.

LEPAS.-Acorn Shell, or Barnacle.

Animal-a Triton: Shell affixed at the base, and consisting of many unequal, erect valves.

THE genus Lepas includes forty-four species, which, for the most part, bear a strong resemblance to each other, at least with regard to their general formation and outline.

The most prominent feature of these shells is their being (with few exceptions) of a more or less conical shape, which is acquired by a number of valves placed perpendicularly on a base, broad at the lower margin, and gradually tapering towards the summit, which is closed by smaller valves, placed horizontally, and serving as a lid or covering to the animal within.

The perpendicular valves are incapable of motion: the horizontal, on the contrary, are moveable at the pleasure 
of the animal; which, through their medium, performs those functions that are necessary to its existence.

The Lepas is never found independent or isolated, as most other shells are; on the contrary, all its species are known to attach themselves in clusters, by their base or fleshy stalk, to other bodies, as rocks, coral reefs, and shells; even fish themselves are not exempt from their encroachments; the whale, for instance, is frequently found with groups of Lepades adhering to various parts of its body. They also affix themselves to ships, and, though at first invisible, so rapid is their increase in magnitude and number, that the velocity of a vessel is considerably impeded by them. I once observed, on the coast of Africa, a piece of wood, which had been placed as a buoy, in a few days become covered with a gelatinous substance, and in less than a fortnight was thickly beset with Lepades. Hence it would appear, that the animal exists in the sea in the state of animalcule.

The exterior of the shell is often varied in form, covering, and colouring; the usual outline is conical; in some, it resembles a pyramid, and in a few is parabolical, or even hemispherical; the Lepas diadema partakes of the latter form and bears some resemblance to a divided globe.

The number of valves which constitute the shell is very indefinite; their usual amount is six, but the Lepas palmipes has sometimes only four; and other species possess the intermediate gradations of number, as far as twentyfour, which number is sometimes exceeded in the L. pollicipes. The valves are variously diversified with strix, ridges, and grooves.

The ridges are mostly longitudinal; the striæ, on the contrary, are transverse, and not unfrequently beset with rough projections and acute spines, as is the case in the Lepas spinosa. 
The colour also differs considerably, though the most usual is of a blueish, purplish, or reddish cast, intermixed with a whitish hue. However, some are marked with black and green alternately, and others are of a greyish-white, or dirty yellow tint, as the L. mitella, \&c.

The valves which compose the lid, or operculum, often vary in number and shape; some species have only two, others three or four, and not unfrequently a much greater number. They are usually attached to a ligament, and sometimes present a pointed or acute form, while in other species they are blunt or obtuse.

The interior of the shells of this genus is either filled up with tubular pores, as in the L. porosa, or divided into separate compartments or chambers, as in the L. quinquevalvis.

Notwithstanding the great affinity that exists throughout the Lepas tribe, there are a few exceptionable species, in which a resemblance is difficult to be traced; as, for example, the L. aurita, L. anserifera, L. anatifera, and others in the second division.

These species are closely allied to each other, but exceedingly dissimilar to the rest of their genus; for the generality of Lepades are affixed to other bodies or substances by the base, or lower part of the shell, whereas these are attached by a stalk, stem, or pedicle, which proceeds from the base of the shell to the substance that sustains it.

The stem by which the shells are supported differs much in quality and substance; sometimes it appears as a smooth, film-like tube, of a texture finer and thinner than gold-beaters' skin, though somewhat lighter coloured, and not unfrequently tinted with bright red or orange; and occasionally it is dark or blueish-brown, much coarser, wrinkled, and granulated.

The L. anserifera and L. anatifera are almost invariably composed of five valves; they are supplied with beau- 
tiful feathery tentacula of a brown colour, and elegantly curled. From this circumstance, probably, they were supposed to be the origin of the barnacle or brent-geese, and are therefore commonly known by the name of Gooseshells or Duck-barnacles. The Lepas anserifera is sometimes found in a fossil state.

The Indian, American, Atlantic, and Arctic oceans, alike provide a habitat for the species of this gemus; and no less than thirteen of them are to be occasionally met with on the British coasts.

The Lepas, in all probability, derives its name from its custom of adhering to crags of rocks, and other projections in the sea.

\section{LEPAS-Acorn, Shell or Barnacle.}

Division I.-AFFixed at THE base to other substances.

\section{FaMiLy 1.-Sessile.}

*Balanus-Common Barnacle. Spinosa-Spinous.

*Balanoides-Small striated. Violacea-Violet.

Tintinnabulum-Bell-shaped. Crispata-Rugged.

*Scotica-Scottish.

*Verruca-Wart-shaped.

*Costata-Ribbed.

*Rugosa $=$ Wrinkled.

*Conoides-Conic.

*Punctatus-Punciured.

Palmipes-Palmated.

Radiata-Rayed.

Cariosa-Ridged.

Minor-Flesh-coloured.

Psittacus-Parrot-beaked.

Angustata-Narrow-mouthed. Hemispherica-Hemispherical.

*Elongata-Club-like. Lævis-Sinooth.

Patellaris-Limpet-like.

*Striatus-Striated.

FAMILY 2.-Having radiated cells at their base.

Diadema-Turban. Testudinaria-Turtle.

Balanaris-Whale.

Quinquevalvis-Five-valved.

Family 3.-IIaving a porous base. 
FAMILY 4.-Having a cup-like appendage at the base. Galeata-Helmet-like.

*Spongeosa-Spongy.

F AMILY 5.-Tubular and truncated at both ends. Tracheaformis-Windpipe.

Division II.-Shells attached to a fleshy peduncle.

FAMILY 1.-Having more than five valves, and a wreath of smaller ones round the base.

Mitella-Mitred. Scalpellum-Knife-like. Pollicipes-Cornucopia.

Famir x 2.-Having only five contiguous valves. Anserifera-Striated. Fascicularis-Bladder-like.

*Anatifera-Duck Barnacle. Vellosa-Downy.

Dorsalis-Wrinkled. Dentata-Toothed.

*Sulcata-Furrowed.

FaMiLy 3.-Having minute and distant valves placed on the fleshy extension of the peduncle.

Aurita-Eared. Vittata-Ribband.

PHOLAS.-STONE-PIERCER.

Animal-an Ascidia: Shell having two primary valves, divaricate, with several smaller differently shaped accessory valves at the hinge; hinges recurved, united by a cartilage; in the inside, beneath the hinge, is an incurved tooth.

IT appears that hitherto only twelve species of this genus have been enumerated, and some of those are so alike, that in many instances they may be considered as mere varieties, rather than different species; however, they all pos- 
sess sufficient determinate characters to prevent any admixture with the genera of Bivalves.

The form of the Pholas is in most species ovate or oblong, which is constituted by two large valves, being situated opposite to each other, and to which is attached, in the vicinity of the beaks, a number of smaller ones, serving as substitutes for a hinge, which, in bivalves, or shells of two opposite parts only, determines their generic character.

Another character of the Pholas is, that the valves, (i.e. the two large ones), never shut close, they are invariably open at one end, and, in most instances, at both.

In the interior of the shell, in each valve, nearly under the beak, is an incurved tooth, sometimes of considerable length, and which may certainly be considered as a peculiarity of the genus.

The exterior of the Pholas is generally destitute of colour; sometimes it partakes of a brownish cast, but the shell is usually of a pure or dusky-white: however, the absence of colour is amply compensated for by the beautiful fret-work with which the shells of this genus are adorned.

In some species the reticulations are so delicate in their fabric, as to resemble the finest lace; in others the texture is coarser, and approaches nearer to small basket-work; and in the Pholas costata the shell is covered with regular, elevated, jagged, or scolloped ribs, so elegantly disposed, as to render it no less desirable for its beauty than its scarcity.

The Pholades are found in company, but not in groups or clusters, as the Lepades are; for each individual Pholas is detached from its neighbour, and occupies a separate and distinct habitation, which it forms for itself, by expressing a corroding juice, in any substance which accident or intent has made most eligible.

Stone, clay, wood, sponge, and coral, equally serve as hac 3 
bitations for the Pholades; even the stoutest oak planks of ships' sides are pierced by them with the greatest facility. As they advance in growth, they enlarge their habitation within, leaving the small aperture, by which they originally entered, of its primitive dimensions, thereby precluding all possibility of a retreat.

The animal possesses the property of emitting a phosphorescent liquor, which shines with brilliancy in the dark, and illuminates whatever it touches.

The American, Indian, and European seas supply the few species that are known.

\section{PHOLAS-Stone-piercer.}

*Dactylus Prickly-piercer.

Costata-Ribbed.

Striata-Striated.

*Candida-White.

* Crispata-Curled.

Orientalis - Indian.
Cordata-Heart-shaped.

Chiloensis-Chili.

Hians-Gaping.

*Parva-Small.

Falcata-Hooked.

*Papyracea-Paper. 


\title{
ORDER II.
}

\author{
BIVALVES.
}

MYA.-Truncateshrough-shell or Gaper.

Animal-an Ascidia: Shell bivalve, generally gaping at one end; linge with broad, thick, strong tecth, seldom more than one, and not inserted into the opposite valve.

THIS genus has been placed by Linnæus the first on the list of Bivalves: its species are by no means numerous, forty only having been described by him.

The principal characteristic of the Mya consists in its gaping at one end: the next general distinguishing mark is, its having a single, broad, patulous tooth, proceeding from beneath the beak. This tooth differs from that of the foregoing genus; for, in the Pholas, it is long and slender, and almost of equal size throughout; whereas, in the Mya it is much wider and broader at one end than the other; and the broadest end has an excavation, which gives it the appearance of the bowl of a spoon or ladle.

However, this sort of tooth is not always discernible in every species of the Mya, for some are entirely without it; others, again, have two or three teeth, and, in some instances, small crenulations supply the place of a regular hinge.

The form of the Mya varies exceedingly, some are ob- 
long and truncate, as if part of the shell had been chopped off; others, again, are orbicular or round; and many are angular and eared.

With regard to their general colouring, little can be said, for the greatest part of them are covered with a thick brown or green epidermis; and when this is removed, no other appearance than that of a livid or wan-coloured surface is exhibited; except in those cases where the substance composing the shell is of a pearly nature, then the removal of the epidermis exposes the hidden beauties of the shell, which, when polished, affords the most brilliant mother-ofpearl imaginable. This pearly appearance is confined to the fresh water species.

The M. margaritifera is famous for the production of the finest pearls, and was formerly found in great quantities in the river Conway, in Wales. The creation of pearls is said to originate in a disease of the animal.

Some species of this genus grow to a large size, the M. glycymeris, for instance, is often found from ten to twelve inches broad. Others, again, as the M. crassa, \&c. are remarkable for their excessive weight and thickness; and their weight often appears out of proportion to their dimensions. Rivers and cataracts afford heavy and thick specimens.

In some places the Mya constitutes a considerable portion of food, not only for man, but also for aquatic birds. They have a propensity to burrow in the sand and mud, and are wholly or partially concealed therein.

Some species of the Mya inhabit the East Indian seas; others are found on the coast of Africa; several are common in the European and Northern seas; and some species are to be found in the South seas; they also occur in considerable abundance in the neighbourhood of Sheerness and Sandgate Creek. 


\section{MYA-Gaper.}

Division I.-Hinge with one or two rounded teeth, not inserted in the opposite valve.

Glycymeris-Great.

*Truncata-Abrupt.

*Arenaria-Sand.

*Declivis-Sloping.

*Pubescens-Pubescent.

*Prætensus-Spoon-hinge.

Anatina-Duck.

Globosa-Globular.

Nicobarica-Nicobar.
Rostrata-Beaked.

*Distorta-Deformed.

* Bidentata-Double-toothed.

* Decussata-Decussated.

*Purpurea-Purple.

*Ferruginosa-Rusty.

Nitens-Glossy.

*Prismatica-Prismatic.

*Substriata-Substriated.

Division II.-Hinge callous, without teeth.

Edentula-Toothless.

Membranacea-Membraneous.
Norwegica-Norwegian.

Siliqua-Bean-pod.

Drvision III.-Hinge with teeth inserted into the opposite valve.

*Batava-Dutch.

*Pictorum-Painter's'.

*Ovata-Oval.

Radiata-Radiuted.

Ponderosa-Ponderous.

Complanata-Smooth.

Nodulosa-Knotted.

*Margaritifera-Pearl.
Corrugata-Wrinkled.

Rugosa-Rough.

Variabilis-Variable.

Nodosa-Knobbed.

Syrmatophora-Angular.

* Suborbicularis-Roundish.

*Inæquivalvis-Inequivalie.

Labiata-Lipped.

Aurita-Eared.

Division IV.-Hinge toothless, with a conical rounded hollow for the reception of the curtilage.

Vulsella-Tweezers. 
SOLEN.-RAZOR-SHEATH OR KNIFE-HANDLE.

Animal-an Ascidia: Shell bivalve, oblong, open at both ends; hinge with a subulate reflected tooth, often double, and not inserted into the opposite valve.

THE number of species in this genus is thirty-five, and in their general appearance they are exceedingly varied.

In some of the species, as in the S. siliqua, S. vagina, \&c. the breadth of the shell is in the proportion of about seven to one of its length, thereby giving it a resemblance to the handle of a knife, or sheath of a razor strop; some, on the contrary, though possessing nearly the same proportions, are curved or bent, like the scabbard of a scimitar, as the S. ensis, \&c. In others, the form approaches nearer to some of the truncated species of the preceding genus, being swollen or puffed up like a bladder. However, by observing both ends of the shell, which will be invariably found open or gaping, there can be little danger of mistaking the Solen for any other genus.

The next characteristic is derived from the hinge, which is usually supplied with one subulate tooth, often found double, though not always inserted in the opposite valve.

The genus Solen, for the most part, presents but little beauty; there are, indeed, some few exceptions-such as the S. radiatus, S. roseus, \&c. these, from being rayed with purple and white, or having a fine pink colour, may perhaps claim admiration; but whatever beauty they may possess, they are infinitely surpassed by innumerable species in the other genera of Bivalves.

Most of the species of Solen are found covered with a thin cuticle or epidermis, which, if not removed, renders the colours beneath obscure, and, in some instances, undiscoverable. 
The European and Northern Seas afford by far the greatest proportion of the shells of this genus. They are, however, found in the Indian, American, and Mediterranean seas. They often reside among zoophytes.

\section{SOLEN-Razor-Sheath.}

\section{Division I.-Shell linear.}

\begin{tabular}{ll} 
*Vagina-Sheath. & Linearis_Slender. \\
Truncatus-Truncated. & *Ensis-Scimitar. \\
*Novacula_Knife. & *Pellucidus-Transparent. \\
*Siliqua_Long brown. & *Legumen-Pease-cod. \\
\multicolumn{2}{c}{ Cultellus-Kidney. }
\end{tabular}

Division II.-Shell ovate or oblong.

$\begin{array}{ll}\text { *Antiquatus-Antique. } & \text { Striatus_Striated. } \\ \text { Gigas-Giant. } & \text { Castrensis_Zigzag. } \\ \text { Magnus-Great. } & \text { Biradiatus-Double-rayed. } \\ \text { Minimus-Small. } & \text { Sanguinolentus-Blood-red. } \\ \text { Guineensis-Guinea. } & \text { Oriens-Rising Sun. } \\ \text { Inflexus-Inflected. } & \text { Occidens-Setting Sun. } \\ \text { Diphos-Violet. } & \text { Amethystus-Amethyst. } \\ \text { Radiatus-Rayed. } & \text { Variegatus-Variegated. } \\ \text { Strigilatus-Strigilated. } & \text { Bullatus-Inflated. } \\ \text { *Coarctatus-Narrow. } & \text { *Minutus-Minute. } \\ \text { *Fragilis-Brittle. } & \text { Virens-Green. } \\ \text { Anatinus-Duck's-bill. } & \text { *Squamosus-Scaly. } \\ \text { Roseus-Rose-colonred. } & \text { Vespertinus-Vesper. }\end{array}$

TELLINA.-TELLEN。

Animal-a T'ethys: Shell bivalve, generally sloping on one side; in the fore part of one valve there is a convex, and in the other, a concave fold; hinge with usually three teeth, the lateral one smooth in one valve.

AMONGST all the different genera of Bivalves, there is none, except the Venus, which can vie with the Tellina in 
point of beauty, variety, or number, which amounts to no less than eighty-one species: and whether the attention be directed to their elegance of form, brilliancy of colour, or delicacy of structure, the eye is equally astonished and delighted.

The usual form of the Tellina resembles a long pear, being broad at one end, and gradually tapering to the other; in some cases so much so, that the pointed termination of the shell forms a perfect beak or proboscis, as in the 'T. rostrata, T. virgata, \&c. Others, on the contrary, are more of an orbicular, or spherical form, as the T. scobinata, \&c. and some again, as the T. radiata, \&c. are nearly allied to species of the Solen genus, with which (from their near resemblance) they are sometimes confounded; however, from the general propensity of all Tellinæ to terminate in a more or less acute beak, much inaccuracy cannot well be committed. At the same time, the hinge of the Tellina will remove any doubts that may have originated from the simple observance of the exterior; for it is usually furnished with three teeth, the middle one often cleft; the lateral teeth are most commonly smooth; the interior margin rarely, if ever, crenulated.

The outside of the shells is surprisingly varied, some being perfectly smooth and polished, whilst others are covered with minute striæ and undulations. In some instances the whole surface is beset with coarse imbrications or scales; but the more elegant species of the Tellina are chiefly remarkable for their beautiful radiations, the colours of which are rarely to be equalled in any of the other genera.

As the Tellinæ are most important among the Bivalves, so the sources from whence they are derived usually abound in the different varieties they afford. The Mediterranean, Adriatic, European and Northern Seas, and the 
American and Atlantic Oceans produce a great number. The rivers, pools, ponds, and marshes of Europe and America supply only a few. The finest varieties are found in the pearl fisheries of Ceylon.

\section{TELLINA.-Tellen。}

Division I.-Ovate and thickish.

Gargadia-Toothed.

Rugosa-Wrinkled.

Lingua-felis-Cat's tongue.

Marginalis-Margined.

Virgata-Tulip.

Interrupta-Freckled.

Angulata-Angular.
Inflata-Inflated.

Polygona-Polygonal.

Lacunosa-Marshy.

Gibbosa-Gibbous.

Gari-Varying.

* Ferroensis-Carnation.

*Fragilis-Brittle.

Obliqua_Oblique.

\section{Division II.-Ovate and compressed.}

Triangularis-Triangular.

Oblonga-Oblong.

Spengleri-Spengler's.

Foliacea-Golden.

Acuta-Sharp-edged.

*Planata-Substriated.

Strigosa-Striped.

Lævigata-Smooth.

Madagascariensis--Madagascar.

Radiata-Radiated.

Pallescens-Pale.

Rostrata-Beaked.

Rufescens-Reddish.

Flavescens-Yellow.

Hyalina-Glassy.

*Inæquivalvis-Inequivalve.

*Trifasciata-Three-banded.
Coccinea-Scarlet.

Incarnata-Flesh-colour'd.

Opalina-Opaline.

Lanceolata-Lance-shaped.

Sanguinea-Sanguineous.

Nivea-Snowy.

Sulcata-Sulcated.

Donacina-Donax.

*Angusta-Narrow.

Truncata-Truncated.

*Punicea-Flat-striated.

*Depressa-Depressed.

*Fabula-Semi-striated.

*Tenuis-Thin.

Vitrea-Transparent.

*Striata-Striated.

Balaustina-Pomegranate.

Calcarea-Chalky. 


\section{Division JII. -Sub-orbicular.}

Remies-Waved.

*Fausta-Obsolete.

* Reticulata-Reticulated.

Cancellata-Cancellated.

*Guinaica-Guinea.

Scabra-Rough.

*Crassa-Thick.

Decussata-Decussated.

Cordiformis-Heart-shaped.

Muricata-Prickly.

Scobinata-Rasp.

*Lactea-Milky.

*Rotundata-Round.

*Flexuosa-Flexuous.

*Carnaria-Rosy.
*Zonata-Banded.

Bimaculata-Double spot.

Balthica-Baltic.

Pisiformis-Pea-shaped.

Divaricata_Obliquely-striated.

Dentata-Toothed.

Digitaria-Digital.

*Cornea-Horn-coloured.

* Lacustris-Lake.

* Amnica-River.

Pusilla_Minute.

Limosa-Maton's.

Fluminalis-Euphrates.

Hermaphrodita-Olive.

Fluminea-Ribbed.

Fluviatilis-Chinese.

\section{CARDiUM.-Cockle or Heart-shell.}

Animal-a Tethys: Shell bivalve, nearly equilateral, equivalve, generally convex, longitudinally ribbed, striated, or grooved, with a toothed margin; hinge with two teeth near the beak, and a larger remote lateral one on each side, each locking into the opposite.

THIS genus, though not so numerous as the last, presents great variety of structure and colouring. There are forty-seven species.

The valves of the Cardium are for the most part of a convex, swollen, or gibbous construction, and often spherical; yet, in some instances, their form is elongated and compressed. In other species the contour exhibits the figure of a perfect heart, as in the C. cardissa, $\& \mathrm{c}$.

The shells are usually equivalve, and have their outsides 
adorned with longitudinal ridges and grooves, crossed by transverse striæ, similar to the common cockle, only much more articulate. In others, again, the ridges are beset with rows of acute spines, as in the $\mathrm{C}$. aculeatum and $\mathrm{C}$. echinatum; but the exteriors of some have a perfectly smooth and polished surface, as the egg-cockle, \&c.

The $\mathbf{C}$. fragum and $\mathbf{C}$. unedo exhibit a peculiar formation, being sub-angular, and only heart-shaped when seen in a particular position. A similar coincidence is observable in the C. retusum, though, in other respects, it differs; for the C. fragum and C. unedo have their ridges covered with crowded pink or yellow elevated lumules or crescents, but the $\mathrm{C}$. retusum has nodules rather than imbricated scales.

The interior margin of this genus is almost universally crenate or toothed.

The hinge is furnished with two teeth, and a larger remote lateral tooth on each side of it, each locking into its opposite.

The C. edule, or common cockle, is found in great abumdance beneath the surface on sandy coasts; the fish affords a wholesome and nourishing food.

The most rare and valuable species of the genus Cardium is the C. costatum or pipe-ridged cockle, which has rows of white hollow elevated ribs, situated at regular distances on its surface, and proceeding in a longitudinal direction from the beaks to the margin; the interstices, or spaces bctween these ribs, are (in perfect specimens) of a fine darkbrown colour, which gives the shell a great boldness of character.

A great part of this genus inhabits the European and Northern seas; many are collected fiom the American, African, and Indian oceans; the Mediterranean, likewise, produces some of the species; and the mouths of rivers, as the Tees, Thames, \&c. also supply specimens, though rarely. 
CARDIUM-Cockle or Heart-shell.

Division I.-Heart-Shaped, valves compressed, UMBONES ALTERNATING.

Cardissa-Venus's heart.

Humanum-Concave.
Roseum-Smooth edged.

Monstrosum-Recurved.

Division II.-Sub-Cordate, LONGitudinally RIBBed.

FAMILY 1.-Having a crescent shaped cavity beneath the umbones.

Retusum-Diana's.

FAMILY 2.-Ribs armed with nodules, elevated rough strice, wrinkles, or scales.

*Edule-Common.

Unedo-Strawberry.

Fragum-White strawberry.

Hemicardium-Heart-shaped.

Tuberculatum - Tuberculated.

Isocardia-Rasp.

Pectiniforme-Pecten.
Regulare-Regular.

Glaucum-Glaucous.

*Fasciatum-Banded.

*Elongatum-Lengthened.

Leucostomum-- White-mouth'd.

Magnum-Yellow ribbed.

Rigidum-Rigid.

\section{Maculatum - Spotted.}

Fanily 3.-With ribs armed, more or less spined.

Flavum-Yellow.

Spinosum-Spined.

*Echinatum-Rake.

Lima-Asiatic.

Muricatum-Prickly.
Rugatum-Gaper.

Latum-Broad.

Ciliatum-Ciliated.

*Aculeatum-Spinous.

*Muricatulum-Minnte.

\section{FamiLy 4.-With ribs unarmed.}

Costatum-Pipe-ridged.

* Medium-Marbled.

Donaciforme-Triangular.

*Exiguum-Pigmy.

Ringens-Toothed.
Oblongum-Oblong.

Papyraceum-Paper.

Fimbriatum-Furbelowed.

Rusticum-Banded.

Islandicum-Iceland.

*Parvum-Diminutive. 
Division III.-Subcordate, obsoletely ribbed, StriatED OR SMOOTH.

FAMILY 1.-Obsoletely ribbed.

*Lævigatum-Smooth.

FAMILY 2.-Lightly striated, approaching smooth. Lineatum-Streaked. Grœnlandicum-Greenland. Serratum-Egg-cockle. $\quad$ Eolicum-Janus.

*Rubrum-Red.

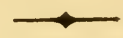

MACTRA.-KNEADING-TROUGH.

Animal-a Tethys: Shell bivalve, unequal sided, equivalve; middle tooth of the hinge complicated, with a small hollow on each side; lateral ones remote, and inserted into each other.

THE genus Mactra has little to boast of, either in regard to beauty or variety. The number of species amounts only to forty-two, and in those no great difference of colouring or form is observable.

The Mactra is usually of a triangular form; but, in some instances, it is rather oblong.

The surface of the exterior is generally smooth, or minutely striated; some exceptions, however, may be found, as the M.plicataria, and others, which exhibit a wrinkled or ribbed appearance, similar to that observed in the different species of the Cardium, but in a reverse direction; the latter being ridged or plaited longitudinally, while, in the Mactra, the elevations and their adjacent grooves are placed transversely.

The generality of Mactræ are of a delicate construction, 
and have a semipellucid appearance. They are, for the most part, thin, brittle, and remarkably light.

The most prevailing colour is blueish or yellowish-white, but some have, upon a brown ground, delicate rays of purple, heightened with rich tints of the same colour: others, again, are of a brilliant lilac, passing into a delicate blue.

The hinge of the Mactra is its best distinction from all the other genera of Bivalves, for the middle tooth is almost invariably complicated, and of a triangular form, having a small hollow on each side; the lateral teeth are remote from the beaks and inserted into each other. The hinge, though very articulate, is remarkably thin and delicate; in some cases, the teeth which compose it are much thinner than paper.

The Mactræ are mostly equivalves; in a few specimens the valves gape at both ends, and in others at the anterior only; the interior margin is rarely crenated or toothed.

The Northern and European seas supply many of the species of Mactræ. The Indian and American oceans, the Mediterranean, the shores of Africa and the Cape of Good Hope also produce them. They are also frequently found at the mouths of rivers.

\section{MACTRA-Kneading-trough.}

Division I.-Shell, subangular.

FAMILY 1.-Having a smooth surface.

Spengleri-Spengler's.

Carinata-Keeled.

Maculata-Spotted.

Corallina-Banded.

Lactea-Milky.

*Cinerea-Ashy.
*Stultorum-Simpletons'.

Grandis--Great.

Achatina-Agate.

*Triangularis-Triangular.

Minutissima-Minute.

Donaciformis-Donar. 
FAMiLy 2.-Having a striated or wrinkled surface.

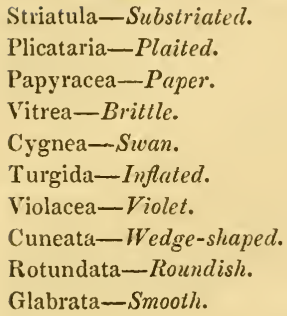

Nitida-Delicate.

Striata-Striated.

*Radiata-Rayed.

*Solida-Strong.

Solidissima-Thick.

*Truncata-Truncated.

*Subtruncata-Abrupt.

Australis-Southern.

Piperata-Pepper.

*Tenuis-Thin.

*Boysii-Boys'.

Division II.-Shell ovate, oblong.

Fabrity 1.-Closed at both ends.

*Glauca-Red-rayed. Rugosa-Rugged.

Egyptiaca-Egyptian.

FAMILY 2.-Gaping at the anterior end.

Pellucida-Pellucid.

*Fragilis-Brittle.

*Listeri-Lister's.

Family 3.-Gaping at both ends.

*Planata-Flattened.

*Lutraria-Muddy.

*Hians-Gaping.

\section{DONAX.-WEDGE-SHELL.}

Animal-a Tethys: Shell bivalve, with generally a crenulate margin, the frontal margin is very obtuse; hinge with. two teeth, and a single marginal one placed a little behind, rarely double or triple.

THE most leading characteristic of the Donax is derived from its form, which (throughout the twenty-four-species) is similar to that of a wedge, being very broad and thick at one extremity, and gradually narrowing and lessening to 
the other. The frontal margin is generally very obtuse, and the anterior slope is not unfrequently furnished with a sort of fissure or gape; near to which is situated a cartilaginous ligature or ligament, which prevents the two shells from separating when the animal has occasion to open them.

Some of this genus, however, are a little ambiguous in their external appearance; so much so, that they frequently create a doubt whether they should not be ranked among the species of the Venus; but in these cases the hinge alone must be the guide, which in the Donax is furnished with two teeth, and a single marginal one placed a little behind, not often double or triple.

The exterior of the Donax is generally of a smoothish surface, though many are covered witl nearly obsolete longitudinal striæ, being embellished at the same time with numerous reddish or purple rays, diverging from the beaks to the margin. Other species are perfectly rough on their outside, which is caused by crowded striæ crossing each other in a longitudinal and transverse direction; this disposition of the striæ gives the shell a foliated and even a spiny appearance, as in the D. scortum and D. pubescens.

A very prevalent colour in this genus is a fine rich purple or purple rays on a white ground; many of the species, however, are of an olive-yellow cast, which not unfrequently inclines to a bright orange; others, again, have a pink hue, and are finely lettered with brown zigzag markings, as the D scripta, \&c. and in some instances the shells have a banded appearance. The interior almost always partakes of the colouring of the exterior; and the margin, which is generally of a high colour, is almost invariably crenulated or beset with small contiguous teeth.

The species and varieties of this genus are but few, and thinly scattered over most parts of the globe; yet some coasts (the European in particular) supply a profusion, but 
of no great variety; they are usually found buried in the sand. It is not exactly ascertained whether any of this genus are natives of rivers.

The Donax derives its name from its shape, which resembles the barbed head of a javelin or dart.

$$
\text { DONAX-Wedge-shell. }
$$

Division I.-With decussated and muricated stria.

Scortum-Beaked.

Pubescens-Spiny.
Muricata-Prickly.

Spinosa-Spinous.

Drvision II.-Longitudinally striated.

Rugosa-Wrinkled.

Serra-Crenated.

*Trunculus-Common.
Striata-Striated.

Denticulata-Toothed.

Incarnata-Flesh-coloured.

Elongata-Elongated.

Division III.-Transversely striated.

Plebeia-Horn-coloured.

Candida-White.

* Castanea-Chesnut.

Radiata-Radiated.

Faba-Bean-shaped.

Cuneata-Wedge.

Straminea_Straw-coloured. Madagascariensis-Madagascar.

Division IV.-Smooth.

Complanata-Single-rayed.

Lævigata-Smooth.
Scripta-Lettered.

Stultorum-Foolish.

Division V.-Shell with transverse membranaceous ridges.

*Irus-Ragged.

VENUS.-VENUS.

Animal-a Tethys: Shell bivalve, the frontal margin flattened, with incumbent lips; hinge with three teeth, all of them approximate, the lateral ones divergent at the tip.

IT has already been observed, that this genus, with regard to beauty, bears a decided pre-eminence over all the 
other genera of Bivalves: and it is in all probability from this very circumstance that it has obtained the title it bears. It contains no less than one hundred and fifteen species; and among these the variety in formation and colouring is almost infinite: many of its species have the frontal margins of their shells somewhat flattened, and not unfrequently with the lips incumbent. The elongated, compressed, angular, and orbicular forms, find a place in this genus, as may be observed on inspecting the four following species: viz. V. literata, V. compressa, and V. tigrina. In some, the form is very much inflated, gibbous, or swollen, as in the V. verrucosa, V. fimbriata, and V. reticulata.

Many of this gemus are remarkable for their smoothness, and the brilliant lustre of their surfaces, such as the $V$. Erycina, V. maculata, V. Chione, \&c. these at the same time are distinguished for their high and rich colouring. Others, again, have less of colour and polish, but more of carved word or reticulations, as the V. Paphia, V. reticulata, \&c. and one species is even spinous, viz. V. Dione.

In many specimens the exterior surface is corered with longitudinal or transverse striæ, sometimes with both, which not unfrequently terminate in foliations near the margins.

The interior of the shells of this genus is often adorned with rich colouring, as in the $\mathrm{V}$. mercenaria or wampum clam, which in fine specimens is of a rich purple. The North American Indians make their wampum or money of the shells of this species. The same shell, in a fossil state, is often found in the Swedish mountains.

The hinge of the Venus, with scarcely any exception, contains three teeth, all approximate or close to each other; besides these three, there is a lateral tooth, not unfrequently divergent at the tip. The inner margin of the shell is sometimes crenulated. 
Almost all parts of the world supply specimens of this genus. The American, African, Eastern, and Western Oceans abound with them. The Mediterranean, Caspian, and Southern Seas likewise produce various species; as also do the European and more northern oceans.

\section{VENUS-Venus.}

Division I.-With the anterior depression spinous.

Dione-Prickly mouthed.

Marica-American.

\section{Division II.-Subcordate.}

Paphia-Paphian.

*Fasciata-Banded. Succincta-Grooved.

*Cingenda-Girdled.

Dysera-Ribbed.

Tiara-Turban.

Plicata-Plaited.

*Excavata-Excavated.

* Spinifera-Spiny.

*Verrucosa-Warty.

Rigida-Rigid.

*Casina-Broad-ribbed.

Cancellata-Channeled.

Subcordata-Subcordate.

*Minima-Red streaked.

* Sulcata-Furrowed.

*Montagui-Montague's

*Scotica-Scottish.

*Danmonia-Devonshire.

Reflexa-Reflected.

*Gallina-Hen.

* Circinata-Compass.

Caliste-Dirty white.

Compressa-Compressed.

Exalbida-Whitish.
Petulca-Clouded.

* Granulata-Grained.

*Ovata-Oval.

Paupercula-Despised.

Flexuosa-Flexuous.

Mactroides-Mactra.

Tripla-Triple.

* Triangularis-Triangular.

Malabarica-Malabar.

Flammea-Brown-band.

Erycina-Polished.

Costata-Ribbed.

Pacifica-South-sea.

* Mercenaria-Money.

*Islandica-Icelandic.

Coaxans-Ceylon.

Lusoria-Sportive.

*Chione-Smooth brown.

Maculata-Spotted.

Casta-Chaste.

Meretrix-Lipped.

Paradoxa-Doubtful.

Læta-Globose.

Pinguis-Sleek.

Triradiata-Three-rayed.

D 2 
Nebulosa-Clouded.

Exilis-Abandoned.

Recens-Recent.

Japonica-Japanese.

Striata-Striated.

Castrensis-Camp.

Pectunculus-Painted.

Lorenziana-Lorenzo.

Ornata-Adorned.

Phryne-Phryne.

Meroe-Meroe.
Callipyga-Arabian.

*Deflorata-Purple-streaked.

Fimbriata-Fringed.

Reticulata-Netted.

Puerpera-Spotted.

Crenulata-Crenulated.

Radiata-Rayed.

Cincta-Girdled.

Squamosa-Scaly.

Lapicida-Rock.

Divergens-Ziczac.

Plumbea-Leaden.

\section{Division III.-Suborbicular.}

*Tigrina-Tiger.

Sinensis-Chinese.

Prostrata-Compressed.

Punctata-Punctured.

Excisa-Defaced.

*Exoleta-Antiquated.

Concentrica-Concentric.

Juvenis-Young.

Histrio-Party coloured.

*Undata-Waved.
Tumidula-Gibbous.

*Borealis-Northern.

Aculeata-Acute-ribbed.

Pectinata-Pectinated.

Discors-Toothed.

Dispar-Unequal.

Equivoca-Equivocal.

Divaricata-Divaricated.

Contraria-Contrary.

Corrugata-Corrugated.

Scripta-Writien.

Division IV.-Shells inflected, with a longitudinal, FURROW ON THE ANTERIOR END.

Pensylvanica-Pensylvanian. Jamaicensis-Jamaica.

Edentula-Toothless. $\quad *$ Spuria-Spurious.

Globosa-Globose.

Division V.-Shells suboval, and slightly angulated ON THE ANTERIOR SIDE.

FAMILY 1.-Smooth or striated.

Gigantea-Gigantic.

Literata-Lettered.
Geographica-Geographic.

Rotundata-Rounded. 

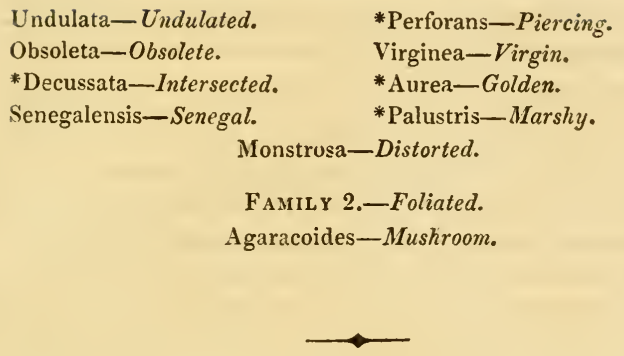

SPONDYLUS.-Thorny Oyster.

Animal-a Tethys: Shell bivalve, solid, with unequal valves: one of the valves convex, the other rather flat; hinge with two recurved teeth separated by a small hollow.

THIS genus, though containing innumerable varieties, is divided into no more than ten species, and even these, from their extreme irregularity of formation and great similarity of appearance, may often be confounded with each other. However, the most striking character of the Spondylus is, that its valves, which resemble those of the common oyster, viz. one convex, the other rather flat, have their outsides covered with longitudinal rows of erect spines or ramifications. The spines are usually tubular, ending in a point; the ramifications or branchings, on the contrary, are flat, jagged, and patulous at their extreme terminations.

The spined Spondyli, as the S. Gædaropus, \&c. are mostly of one colour, as orange-red, purple, white, brown, or yellow; which colours, in fine specimens, are exceedingly brilliant.

Those which have branches or plaits, (as the S. plicatus $\& c$.) have, on the contrary, a ground colour of either of the 
above-mentioned tints, and the ramifications are left entirely white.

In some instances there is a compound of colouring, as white and brown, purple and white, \&c. which gives the shell a pied or brindled appearance; and in others (especially those which have a tendency to being foliated as well as branched) the upper valve is of one colour, as purple or brown, while the lower valve is perfectly white.

The valves of the Spondyli are generally unequal, the lower one protruding much beyond the other, and often terminating in a curved and lengthened beak.

The hinge is furnished with two recurved teeth, which are very strong and articulate, and separated by a small but deep hollow; the inner margin is mostly crenulate; and highly coloured with orange or purple. Some of this genus, like the escallops, are summonnted with ears on each side of the beaks; others, on the contrary, are perfectly earless.

They are generally found adhering to rocks, corals, \&c. in groups more or less numerous, often forming large masses, and sometimes attached to shells. They are to be met with in the American, Indian, Mediterranean, and other seas.

SPONDYLUS-Thorny Oyster.

Division I.-Shell armed with SPINES or Ramifications.

Family 1.-Sharp spines.

Gædaropus-Thorny red. Aurantius-Orange.

Regius-Royal. Citrinus-Yellow.

Histrix-Hedge-hog.

FAMrLy 2.-Having palmated or foliated ramifications. Palmatus-Palmated. Spathuliferus-Pied.

Ducalis-Ducal. 


\section{Division II.-Shell unarmed.}

FAMILY 1.-Upper valve longitudinally striated. Anacanthus-Spineless.

FAMILY 2.-Valves longitudinally plaited. Plicatus-Plaited.

CHAMA.-Clamp, Clam, or Gaper.

Animal-a Tethys: Shell bivalve, rather coarse; linge with a callous gibbosity, obliquely inserted in an oblique hollow; anterior slope closed.

THIS genus is by no means numerous, containing only twenty-seven species, which, for the most part, are rough and uncouth looking shells. The C. cor is, however, an exception, it being usually smooth: from its beauty and peculiarity of structure, it is signalized from every shell in the numerous catalogue of Bivalves. This species, which varies in size from two to five inches in diameter, bears a strong resemblance to a heart; its top being surmounted by beaks which wind round towards the hinge in the most. graceful curvature possible.

The genus Chama affords a subject for amazement rather than admiration, for some of its species grow to an umcommon size: the C. gigas, for instance, (or Giant clam), is a specimen of the unusual magnitude to which shells of this genus attain; the valves sometimes exceeding four feet in breadth, and of the enormous weight of five humdred pounds; but so disproportionate are its varieties, that some have been found measuring only half an inch. This species is generally more or lesss ribbed and foliated, 
and sometimes imbricated or scaly; the usual colour is a dirty white, but the rarest varieties are those which have a fine red-pink, or yellow tinge. Some of them, when perfect, are highly prized. The cartilage of the hinge has a dull brown colour, but, when polished and cut in ovoid, its iridescence is so brilliant that it rivals the opal in beauty, and has even been sold for it. The $\mathbf{C}$. hippopus also deserves to be noticed; like the $\mathbf{C}$. gigas it varies considerably in size, and is frequently found a foot long, while some specimens do not exceed an inch; it is usually of a yellowish colour, with pink spots and murications.

A grand mark of distinction in this genus is, that the posterior slope is usually open or gaping, and the anterior closed, not unfrequently having its margin crenulate. The valves are mostly inequilateral, one protruding beyond the other, and often appearing as if deformed. The hinge has generally a callous gibbosity, inserted into an oblique hollow.

The C. concamerata is remarkable for having, in the interior of each valve, an ovate chamber, which gives the shell an appearance of being double.

The more beautiful species of this genus are richly foliated or spined, -as the C. lazarus, C. gryphoides, and C. arcinella; the varieties of which are sometimes worthy of admiration.

It seems a principle with the Chamæ, (like the Spondyli), to affix themselves to any extraneous substance which accident may throw in their way. They often adhere to rocks, stones, and various shells; but, in many instances, they seem to have a preference for some particular genus of shells; for the C. arcinella is most commonly found affixed to that species of Murex called the Thorny Woodcock; however, it retains a partiality for others of the Murices, especially those often known under the name of Triplices. 
The American, Indian, and Atlantic Oceans; and the Mediterranean, Caspian, and Adriatic Seas, produce infinite varieties of this genus.

\section{CHAMA-Clam.}

\section{Division I.-Shell equivalve.}

Fayily 1.-With longitudinal ribs, gaping at the posterior slope. Gigas-Giant. Hippopus-Spotted.

FAMILY 2.-With longitudinal ribs, posterior slope closed. Antiquata-Antiquated. Ajar-Ajar. Calyculata-Variegated. Trapezia-Trapeziform. Satiata-Obsolete. Rosea-Rose-coloured. Rugosa-Rugged.

FAM1LY 3.- Shell longitudinally ribbed, having an ovate chanber in the interior of each valve.

Concamerata-Chambered.

FaMıL 4.-Shell decussated, or transversely striated, witkout ribs.

Semiorbiculata-Brown.

Oblonga-Oblong.

Cordata-Heart-shaped.

Coralliophaga-Coral.

FAMILY 5.-Shell tuberculated. Plumbea-Leaden.

Family 6.-Heart-shaped, umbones prominent, and apices spirally recurved.

*Cor-Heart.

Moltkiana-Moltkian's.

Division II.-Shell inequivalve.

Lazarus-Lazarus.

Gryphoides-Gryphus.

Cornuta-Horned.

Sessilis-Scaly.
Lamellosa-Lamellar.

Punctata-Dotted.

Sinistrorsa-Reversed.

Arcinella-Hedge-Hog.

Ponderosa-Heavy.

D 3 
ARCA.-ARK.

Animal-a Tethys? Shell bivalve, equivalve; hinge with numerous sharp teeth, alternately inserted between each other.

THE Arca, of which there are forty-five species, are readily distinguished from other bivalves, by the peculiarity of the hinge; which, without exception, is composed of numerous sharp teeth, alternately inserted between each other. The line of direction of the hinge admits of two variations: in some species, as the $\mathrm{A}$. Noæ, A. barbata, $\&$ c. it is perfectly straight; in others, as the $\mathbf{A}$. pectunculus, A. pilosa, \&c. it is arched or curved.-However, in all the species, the same description of hinge exists, though in some it may be differently situated.

The forms of the Arks vary exceedingly; some are elongated, as the A.tortuosa, A. Noæ, and A. barbata: in the A. barbata or bearded Ark, the greater part of the surface of the shell is concealed by a thick bristly or hairy covering.

The subcordate form is exemplified in the A. senilis, A. granosa, \&c. which are, besides, somewhat gibbous, and have usually smooth or muricated grooves.

The third form is the suborbicular, of which the A. glycymeris and $A$. pilosa are sufficient examples; they are for the most part smooth on the outside, except where the longitudinal striæ are placed: these striæ are frequently more articulate in the interior than on the exterior, and often terminate, at the inner margin, in elevated teeth. The shells of this genus are covered with a brownish or greenish black epidermis.

There are many Arks which gape at the outer margin; others, on the contrary, are perfectly close. Some have 
the margin entire; others, again, are crenulated; and several have prominent angular slopes, which give the shell an auriculated appearance; the anterior slope is, however, by far the most prominent of the two.

This genus presents but little beauty, though some of its species are considered rare.

The Ark is found in the European, Indian, American, and Atlantic oceans: the Baltic, Northern, and Red seas also produce some species.

\section{ARCA-Ark.}

1) IVISION I.-With THE TEETH OF THE HINGE IN A STRAIGHT LINE.

Famir 1.-Shell twisted.

Tortuosa-Twisted.

\section{Fanily 2.-Shell rhomboidal.}

*Nuæ-Noah's.

* Imbricata-Imbricated.

Navicularis-Boat.

Plicata-Plaited.
Candida-White.

Indica-Indiun.

*Lactea-Milky.

Reticulata-Reticulated.

FAMiLy 3.-Shell oblong or transversely ovate.

Magellanica-Magellanic.

Lacerata-Hairy.

Fusca-Brown.
Bicolorata-Party-coloured.

Modiolus-IIuscle.

Corbula-Basket.

Senegalensis-Senegal.

Family 4.-Shcll subcordate.

Lavigata-Smooth.

Pella-Brittle.

Antiquata-Antiquated.
Granosa-Grained.

Rhombea-Rhomboid.

Senilis-Rugose.

$$
\text { Fanily 5.-Gaping. }
$$

Complanata-Compressed.

* Barbata-Bearded.
Nivea-White.

Cancellata-Cancellated. 
Family 6.-With an ear-shaped appendage in the interior of each valce.

Concamerata-Chambered.

Division II.-With the teeth of the hinge in a CURVED LINE.

FaMiLY 1.-Subcordate.

Campechensis-Campeachy. Iquilatera-Equilateral.

Angulosa-Angular.

FamiLy 2.-Suborbicular, margins crenated or plaited.

Pectunculus-Spotted.

Pectinata-Comb.

Decussata-Decussated.

Pallens-Pale.

Undata-Lettered.
*Glycymeris-Orbicular.

*Pilosa-Downy.

Stellata-Starred.

Scripta_Lettered.

Nummaria-Coin.

Family 3.-Suborbicular, margin entire.

Multis-striata-Many-striped.

Division III.-With the teeth of the hinge produced AND SHARPLY POINTED.

*Nucleus-Silvery.

*Minuta-Small.

*Rostrata-Beaked.

*Tenuis-Thin.

\section{OSTREA.-Oyster and Scalizop.}

Animal-a Tethys: Shell bivalve, generally with unequal valves, and slightly eared; hinge without teeth, but furnished with an ovate hollow, and mostly lateral transverse grooves.

THERE are no less than eighty-eight species in this genus, which present considerable variety in beauty and form. 
The Ostreæ are divided into several classes: the first and second comprise the innumerable varieties of escallops or scallop shells, and are distinguished from each other by the proportion of their ears; the third and remaining divisions include the species somewhat resembling the common oyster.

The first division is, for the most part, composed of very elegant specimens : their form is usually regular, and their surface is adorned with elevated divergent ribs, in number from five to forty, which proceed from the tip of the beaks to the extremity of the margins, and there terminate in a fine scalloped or Vandyked outline, describing in their course the most graceful expansion possible.

The greater number of the species of this genus are inequivalve, that is, the degree of convexity differs in the two valves of the same specimen, as in the O. ziczac, O. jacobæa, \&c. which invariably have the upper valve flat, and the lower convex. However, in other species, as the O. pallium, (ducal mantle), \&c. the shells are equivalve, i. $e$. both possess the same degree of rotundity and gibbosity.

It is remarkable, that in many of the Ostreæ the colours of the upper valve are brighter than those of the lower: this is particularly observable in the $\mathrm{O}$.pleuronectes, known by the name of the Compass or Flounder Pecten, which has one valve perfectly white, and the other of a brownish or reddish cast. This species has also another peculiarity, viz. that it invariably gapes at both ends; whereas, in other species, the gape is only at one end.

The situation of the beaks often varies considerably; in some, as the O. maxima, O. jacobæa, \&c. they are placed in the centre; whereas, in the O. lima, O. glacialis, \&c. they are situated obliquely, or on one side, which gives the outline of the shell an appearance of slight distortion, occasioned by one margin being straight and flattened, while the other remains round and inflated. 
There is also considerable variation in the size and form of the ears, which in some species are nearly of the same dimensions; but, in many, one is much larger than the other; and in a few, they are hardly discernible.

The ears of many of the scallops are almost smooth on the outside, but some are rough, and even spined. The O. pallium and others have one ear ciliate, and are spined within.

The exterior of the shells, as has been before observed, is usually covered with elevated longitudinal ribs and grooves, which are variously diversified with beautiful colours and fine chequer-work. The ribs are mostly covered with undulated and transverse striæ, not unfrequently assuming the appearance of elevated scales, as in the O. imbricata. In others, again, the striæ are crenated, as in the O. radula; and some, as the O. nodosa, \&c. have large knobs or tubercles raised upon the ribs.

The margins of the interior of the Ostrea are generally crenated, and often beautifully coloured.

The hinge is universally without teeth, and furnished with an ovate hollow; in the vicinity of which are placed lateral transverse grooves, rumning in a parallel direction in both valves, but not locking into each other, as in the genus Arca.

The common scallop, O. maxima, is found in most European seas, in large beds, from which they are dredged by the fishermen, and afterwards pickled and barrelled for sale; they are also sometimes brought to market in the state in which they are caught, and are eaten fresh. These shells were formerly worn by pilgrims on their hat or coat, as a mark of their having crossed the sea for the purpose of paying their devotions at the holy shrine, in Palestine: in commemoration of which, they are still preserved in the armorial bearings of many families of distinction.

The scallops are found harbouring among fuci and zo- 
ophytes: they have the faculty of leaping out of the water, and are enabled to effect a very rapid motion, by opening and closing their valves.

The third division of Ostreæ consists of those which in construction, substance, and colouring, are more nearly allied to the common or eatable oyster. The species of these divisions are of a much more irregular form than the scallops, and are usually very rugged, unfinished looking shells. The hammer oyster, O. malleus, is perhaps the most remarkable of this class; its form resembles that of a long-headed hammer, or more properly a pick-axe: there are two distinguishable varieties of it, viz. the white and the black, both of which, when in fine preservation, are considered rare and valuable. These shells are rough and plaited on the outside, but their inside is smooth and glossy, having a steel blue colour or metallic lustre diffused over the surface.

The hinge of some of the species, as the $O$. perna and $O$. isognomon, has a perpendicular grooved line attached to it. . Some, again, as the O. lima, \&r. gape at the hinge; others terminate in a long beak from the linge upwards, as the $\mathbf{O}$. virginea.

The species of the fourth division-are parasitical, and some have the appearance of a dried leaf, as the O. folium, \&c. which often adhere to the roots and stumps of trees, especially the mangrove, and are also found affixed to the gorgoniæ.

The $\mathrm{O}$. crista-galli and the other species of the third family of the fourth division were, in the former editions of this work, which closely adopted Gmelin's arrangement, classed among the Mytili; but, guided by the character of the shells, we have removed them to this genus, to which they indisputably belong. These attach themselves to foreign bodies by a formation of the shell itself, which has the appearance of several distinct claws or hands. 
The common oyster (O. edulis) is too well known for its nutritious and palatable properties to require much description; suffice it to say, that the exterior of the shell is usually covered with undulated and imbricated scales, of a yellowish or pinkish olive cast; and the old shells are often covered with various adhesions, such as anomiæ, serpulæ, lepades, sertulariæ, and other marine productions. The interior of the shell has generally a pearly appearance, and specimens are often found containing pearls. They are to be met with in most seas, occasionally in clusters, affixed to rocks and other substances. In some places they are considered so profitable a branch of traffic, that the greatest care is taken to promote their generation and growth. By proper management their multiplication becomes immense. They are often formed into large layers or beds, extending many miles; which, in favourable seasons, prove a submarine mine of wealth to their proprietors.

Ostreæ are found in every part of the world; but the most rare are produced in the Indian seas.

\section{OSTREA-Oyster or Scallop.}

Division I.- Valves with ears equal.

FaMII Y 1.-Valves ribbed, upper valve fat.

$\begin{array}{lc}\text { * Maxima-Greatest. } & \text { Ziczac-Zigzag. } \\ \text { *Jacobæa-Lesser. } & \text { Striatula-Sixte€n-rayed. } \\ & \text { Minuta-Minute. }\end{array}$

FaMiLy 2.-Valves ribbed, ears equal.

Hybrida-Hybrid. Imbricata-Imbricated.

Radula-Rasp. Plica-Folded.

Hians-Gaping.

FAMLY 3.-Valves flattish on one side and gaping. Lima-File.

*Fasciata-Banded. 
Bullata-Swollen.

Fragilis-Brittle.

Scabra-Rough.
Glacialis-Icy.

Excavata-Hollow.

*Loscombia-Loscomb's.

FAMILY 4.-Valves smooth or striated, and not closing.

Pleuronectes-Sole. Japonica-Japanese.

Magellanica-Magellanic.

Division II. - Valves with unequal ears.

Family 1.-Valves ribbed.

- Pes-lutræ-Otter's-foot.

Pallium-Ducal Mantle.

Sanguinolenta-Blood-spot.

Palliata-Variegated.

Nodosa-Knobbed.

Pes-felis-Cat's Foot.

Sulcata-Sulcated.

*Cinnabarica-Red.

Senatoria-Senator.

Citrina-Yellow.

Pellucens-Pellucid.

Obliterata-Worn.

Sanguinea-Scarlet.

Porphyria-Porphyry.
*Varia-Variegated.

Sauciata-Unequal-rayed.

Pusio-Wrinkled.

* Sinuosa-Distorted.

Miniata-Vermilion.

Triradiata-Three-rayed.

Solaris-Solar.

Glabra-Glabrous.

* Opercularis-Painted.

*Lineata-Lined.

Nucleus-Kernel.

Gibba-Gibbous.

Turgida-Turgid.

Pyxidata-Box-like.

Flavicans-Yellow.

FaMILY 2.-Valves smooth.

Tigrina-Tiger.

Fuci-Fucus.

Exotica-Exolic.
Vitrea-Glassy.

*Obsoleta-Obsolete.

*Lævis-Smooth.

Proteus-Variable.

Division III.-Oblong, LiNEAR.

FAyILY 1.-With a transverse lobe on each side of the hinge.

Malleus-Hammer.

FAMILY 2.-With a slight beak on one side of the hinge.

Figurata--Figured. 
FAMILY 3-Rounded at the hinge.

Regula-Tongue-shaped.

FAMILY 4.-Valves diverging at the hinge, and the inside vaulted.

Fornicata-Vaulted.

Division IV.-Parasytical, or attached to other SUBSTANCES.

FAMILY 1.-With one valve produced at the summit. Cucullata-Hooded. Virginea-Virginian. Forskalii-Forskael's.

Rostrata-Bealed. Cristata-Crested. Sinensis-Chinese.

FAMILY 2. $\rightarrow$ With the valves nearly equal. Orientalis-Indian. Orbicularis-Orbicular. Folium-Foliated. Arborea-Tree. Plicata-Plaited. Senegalensis-Senegal.

FAMILY 3.-With the ralves strongly plaited longitudinally. Crista-galli-Coxcomb. Hyotis-Horned. Frons-Crested.

Division V.-With the hinge composed of transverse FURROWS IN A STRAIGHT LINE.

Crenatula-Crenated. Semiaurita-Half-eared.

Perna-Oblong.

Isognomon-Long-linged.
Ephippium-Saddle.

Alata-Winged.

Picta-Painted.

Legumen-Pod-shaped.

Division VI.-Valves shightly striated, Lower valve TURNING UP AT ITS SIDES, AND THE CARTILAGE OF THE HINGE PLACED IN A DEEP NARROW GROOVE.

Spondyloidea-Spondyloid. Ovalis-Oval.

Divison VII.-Valves coarse and RugGed, and not conPREHENDED IN THE FORMER DIVISIONS.

Denticulata-Toothed.

*Edulis-Eatable. 
ANOMia.-Anomia or Antique Lamp.

Animal-an emarginated, ciliated, strap-shaped body, with bristles or fringe affixed to the upper valve; arms two, linear, longer than the body; connivent projecting, alternate on the valve, and ciliate on each side, the fringe affixed to each valve: Shell bivalve, inequivalve, one of the valves flattish, the other gibbous at the base, with a produced beak, generally curved over the hinge; one of the valves often perforated near the base; hinge with a linear, prominent cicatrix, and a lateral tooth placed within, but in the flat valve, on the very margin; two bony rays for the base of the animal.

OF this curious genus of Bivalves there are thirty species.

The shells are usually inequivalve, one of them often flattish, the other gibbous at the base, terminating in a produced beak, which curves upwards over the hinge. There is frequently a small perforation near the base, through which the animal thrusts a strong ligament, whereby it affixes itself to different marine substances, as fuci, crabs, spines of echini, and especially to the stars of the Madrepora prolifera.

The Anomiæ differ materially in form, some resembling the shape of an oyster, as the A. cepa, A. ephippium, \&c., all of which have the lower valve flat and perforated. Others, again, are imperforated and nearly orbicular, as the $A$. craniolaris, A. placenta, \&c., and some are oblong, as the A. bifida, \&c. Many of them, when viewed in profile, resemble the form of an antique lamp, as the A. caputserpentis, \&c. and a few are very similar to the hooked or curved beak of a parrot, as the A. psittacea, \&c. 
The hinge of the Anomia admits of considerable variation; but its most leading character is that of being furnished with a linear prominent cicatrix, and a lateral tooth placed within. On the margin of the flattest valve in many species are placed two bony rays, or linear callosities, which serve as a base for the animal; but some have only one in each valve.

The interior of the shell is often silvery, and the margin is frequently crenated, notched, or toothed, but in many it is perfectly entire.

The prevailing colour in this genus is that of a dirty yellow, or dusky white; however, some are bright yellow, as the A.electrica. The A. cepa (the onion peel), and the A. sella (the saddle oyster), have a fine coppery or bronzelike appearance; and the $\mathbf{A}$. Capensis and $\mathbf{A}$. sanguinea exhibit a beautiful pink or red colouring. The A. psittacea, and other similar species, have a dingy or olive black colour, and a few are found of a shining jet black.

Some of the Anomiæ are almost smooth; others, on the contrary, are ribbed and striated, as the A. muricata, which is covered with scales and hollow spines of considerable length; and others decline on the fore-part, and have a groove or channel running down the middle of the shell.

The Anomiæ are generally thin and delicate shells, and usually semitransparent. The A. placenta (the cake) but commonly called the Chinese window oyster, when in a young state, becomes so transparent by the process of polishing, that it is frequently made use of by the ingenious Chinese as a substitute for glass.

The European, Indian, American, and African oceans supply many species of the Anomia, as also do the Mediterranean and Northern seas. 
ANOMIA-Anomia.

Division I.-Lower valve flat and perforated.

Craniolaris-Cranium.

Turbinata-Top-shaped.

*Ephippium-Orbicular.

*Cepa-Onion.

*Electrica-Small-amber.

Punctata-Dotted.
*Aculeata-Prickly-valved.

Muricata-Muricated.

*Undulata-Striated.

Patelliformis-Limpet-shaped.

Squama-Scaly.

Bifida-Bifid.

*Cylindrica-Cylindrical.

Division II.-Having the umbo perforated, and generally a cartilaginous substance in the interior of the shell.

Scobinata-Rough.

Aurita-Eared.

Retusa-Blunt.

Truncata-Truncated.

Capensis-Cape.

Decollata-Semicircular.

Pubescens-Downy.
Sanguinea-Scarlet-rayed.

Caput-serpentis--Snake's-head.

*Terebratula-Lamp.

Cranium-Brittle.

Cruenta-Blood-red.

Dorsata-Keeled.

Psittacea-Parrot-beak.

\section{Rosea-Pink.}

Diyision III.-Imperforated, and having a truncated triangular hinge.

Placenta-Cake.

Sella-Saddle. 


\section{MYTILUS.-Muscle.}

Animal allied to an Ascidia: Shell bivalve, rough, generally affixed by a byssus or beard of sillyy filaments; hinge mostly without teeth, with generally a subulate, excavated longitudinal line.

OF the genus Mytilus there are enumerated forty-six species; though some of these are a little indistinct in character, yet the greatest proportion of them bear a near alliance to the general form and habits of the common or eatable muscle. There are, indeed, a few exceptions, such as the M. margaritiferus (true mother-of-pearl shell), and others of a similar description; some of which we have removed from the position they occupied in this genus in the former editions of the present work, into the third family of the fourth division of the Ostrea genus, as they exhibit strong evidence of belonging to that genus.

The hinge of the Mytilus is usually without teeth, having generally a subulate excavated line in place of them. Some species have, however, little denticulations with alternate grooves, which vary in number from ten to fifty; in the M. niger, which has the greatest number, they amount to one hundred.

The general appearance of muscles differs greatly: some being perfectly smooth, and beautifully marbled and variegated with fine colouring; others are elegantly radiated with purple and white, like a tulip; and some again are coarsely ribbed and grained with minute tubercles, and of one colour only, such as black, blue, green, yellow, or brown. Most of them are indebted to their epidermis for whatever outward colour they may possess; when this is removed, so different a surface is often presented, that even an adept 
might be puzzled to recognise two shells of the same species. In some specimens the epidermis is bearded or shaggy. In a few instances, the valves gape, as in the M. bilocularis, and other similar species.

The greater part of this genus exhibit internally a pearly appearance, and some (when uncoated and polished) afford the brightest radiance possible. The M. margaritiferus is admired for the iridescent colours it displays, and is, moreover, famous for the fine and valuable pearls it engenders within its silvery valves. The young shells of this species are sometimes so different to the adults in appearance, that they can scarcely be known for the same.

Some of the Mytili possess the faculty of penetrating coral-rocks, hard marble, and limestone. Of this class are the M. lithophagus and M. rugosus; the latter is sometimes found in lakes as well as in the sea.

A few species, on a superficial glance, might be mistaken as belonging to the genus Mya; viz. the M. latus, M. discors, and M. ungulatus; but, by a minute inspection of the hinge, the error would soon be discovered.

The M. edulis affixes itself to other bodies, by means of a silky byssus; it is found in immense beds or layers, consisting of many myriads.

The M. cygneus and M. anatinus, (both fresh-water species), frequently become the food of birds and aquatic fowls.

The Mytili from the rivers in Africa are often of great beauty when polished, and exhibit fine colours.

The Indian, Atlantic, American, and Northern oceans produce many species; some are also from New Zealand, the Mediterranean, Russian, and Red seas. 


\section{MYTILUS-Muscle.}

Division I.-SHell oblong, UMBONes or APICES TERMINAL AND POINTED, SLIGHTLY ANGULATED AT ONE SIDE, AND ROUNDED AT THE LOWER MARGIN.

*Edulis-Eatable.

*Pellucidus-Pellucid.

Vulgaris-Small.

Bilocularis-Two-celled.

Ungulatus-Ox-hoof.

Exustus-Rose-coloured.

Striatulus-Striated.

Niger-Black.
Latus-Broad.

Perna-Lengthened.

Smaragdinus-Green.

Confusus-Wedge-shap'd.

Bidens-Double tooth'd.

Puniceus-Ventricose.

Demissus-Silvery.

Ruber-Red.

Division II.-Transversely ovate, with longitudinal RIBS ON EACH SIDE, AND PLAIN OR STRIATED IN THE MIDDLE.

*Discrepans-Compartment. *Discors-Discordant. Impactus-Wool-coated.

Division III.-Found burRowed in rocks, corals, \&c.

Lithophagus-Burrowing. Aristatus-Crossbeak'd.

*Ambiguus-Ambiguous.

*Rugosus-Rugged.

Coralliophagus-Coral-piercer.
*Præcisus-Truncated.

Fuscus-Brown.

Plicatus-Plaited.

Niveus_Snow-white.

Arborescens-Dendritical.

Division IV.-Shell oblong, gibbous, with the posTERIOR SIDE DILATED AND ELEVATED ABOVE THE HINGE, APEX ROUNDED.

*Modiolus-Great.

Division V.-Only found in Fresh water.

* Cygneus-Swan.

Fluviatilis-River.

Stagnalis-Stagnant.
*Anatinus-Duck.

*Fucatus-Avon.

Dubius-Doubtful.

Americanus-American. 
Division VI.-Eared.

FAMiLY 1.-Valves rather compressed.

Margaritiferus-Pearl. Radiatus-Rayed.

Unguis-Nail.

Family 2.-With one valve more convex than the other. Hirundo-Swallow. Morio-Mulberry. Ala-corvi-Crow's wing.

Drvision VII.-Shell SUborbicular, LONGitudiNally STRIATED, AND MARGIN CRENULATED.

$$
\text { Faba-Bean. }
$$

Division VIII.-Somewhat tongue-shaped, APICES ACUTE.

Lingua-Tongue. Camellii-Camellius'.

PINNA.-Fin-Shell, Nacre, or Sea-Wing.

Animal-a Limax: Shell bivalve, fragile, upright, gaping at one end, and furnished with a byssus or beard; hinge without teeth, the valves united into one.

THE number of species contained in this genus is limited to twenty-one, and some of those are so alike, as barely to admit of being called distinct.

The usual form of the Pinnæ is allied to that of the larger species of muscles, being long and tapering, narrow at the beaks, and gradually expanding to a considerable breadth at the opposite extremity: there are some instances where the form is more compressed.

The Pinnæ are by no means so entire or solid as the muscles, for they are (with few exceptions) exceedingly 
brittle or fragile in substance, and almost invariably gape at one end.

'The greatest portion of the Pinnæ have longitudinal ribs, on which are placed elevated transverse striæ, often terminating in imbricated arched scales, and prominent canaliculated tubular spines; the P. rudis and P. muricata may be adduced as examples: in the younger shells of these two species, the spines appear only as minute prickles. In other specimens, as the P. saccata (satchel), \&c. the ribs are not so articulate, but are more undulated, and perfectly free from scales or spines.

The Pinnæ have usually a horn-like appearance, which is often overcast with a steel-blue or copper-coloured gloss. The hinge is invariably without teeth; the valves nevertheless adhere so closely in the region of the beaks, that they appear as if united together.

Some of the young shells of this genus are less than an inch in length, but the adults often exceed three feet.

This genus produces, in large quantities, a very fine sort of byssus or beard, which the Maltese frequently convert into sundry articles of wearing apparel, vieing in appearance with the finest silk.

The Pinnæe are usually found in smooth water and bays, with the smaller end sticking in the mud or sand, and the wide end a little open. The animal, in some places, is accounted excellent food.

The Mediterranean produces Pinnæ in great number: they are also to be found in the Indian, American, Atlantic, and European oceans; as well as in the Adriatic and Red seas.

The Pinna, probably, derives its name from its resemblance to a wing or fin of a fish. 
PINNA-Sea Wing.

Division I.-Shells longitudinally ribbed.

Rudis-Rough.

Adusta-Pear-shap'd.

*Pectinata-Spiny-ribb'd. Vexillum-Bunner.

Inflata-Inflated. Squamosa-Scaly.

*Carnea-Flesh-colour'd. Vitrea-Brittle.

Rigida-Rigid.

Nobilis-Great.

Papyracea-Paper.

Muricata-Prickly.

Saccata-Satchel.

Cancellata-Cancellated.

Divisiox II.-Shell nearly smooth and plain.

Nigra-Black.

*Ingens-Scotch.

Bicolor-Two-colour'd.

Rotundata-Giant.

Incurva-Incurved.

Digitiformis-Finger-shap'd.

Lobata-Lobed. 


\section{ORDER IIT.}

\section{UNIVALVES}

1. SHELLS OF ONE PART ONLY, AND HAVING A REGULAR SPIRE.

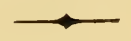

ARGONAUTA.-Paper SaILor.

Animal-a Clio: Shell univalve, spiral, involute, membranaceous, one celled.

THE genus Argonauta contains but nine species: in so small a number, much variety is not to be expected.

The form resembles a scroll, with a large aperture. The surface is ornamented with canaliculated grooves, proceeding from the summit to the outer margin, which is generally bicarinated; but in the $A$. vitrea (the glassy nautilus) the margin is single: this is the most rare and beautiful species of the genus.

The Argonautæ are remarkable for their excessive thinness, brittleness, and lightness. The A. argo, usually known by the name of the Paper Nautilus, is supposed, in the early ages of society, to have first taught men the use of sails.

A mucilaginous animal, called Poulpe, is often mistaken for the Paper Nautilus; it is seen sailing on the ocean with 
its arms erect, and a membrane thrown out between them, by which means it is driven forward, like a vessel under sail. The Mediterranean often has large fleets of these diminutive navigators floating upon its caln surface.

The colour of the Argonautæ is mostly blueish, or yellowish-white, having the keel often tinged with a brownish hue.

As to size, the Argonautæ differ greatly; the A. argo, for instance, often attains ten or twelve inches in width; while the $A$. cornu and $A$. arctica seldom exceed three or four lines in diameter.

The Mediterranean and Indian seas produce some varieties; others are found at the Cape of Good Hope; and some inhabit the Northern and Greenland seas.

They are supposed to have derived their name from the Argonauts.

\section{ARGONAUTA-Paper Sailor.}

Division I.-KeEl toothed.

Family 1.- Summit interiorly curved.

Argo-Oriental. Hians-Gaping.

Tuberculata-Tuberculated. Gondola-Boat.

Haustrum-Bucket.

Fanily 2.-Summit exteriorly curved.

Vitrea-Brittle.

Division II.-KEEL Not TOOTHED.

Cymbium-Minute.

Cornu-Horn-shap'd.

Division III.-UMBILICUS PERFörated.

Arctica-Arctic. 


\section{NAUTILUS.-PEarLy SaILOR.}

Animal-(vide Rumpf. Mus. tab. 17, fig. B.) Shell univalve, divided into several compartments, communicating with each other by an aperture.

THIS genus contains thirty-six species, which are all nearly allied in general formation and structure. The most characteristic mark of the genus is, that the whirls are generally divided into distinct compartments or chambers, connected by a slender siphon, which runs spirally through the shell. This siphon is in some species central, and in others contiguous to the surface.

The shells of the first and second divisions are spiral or scroll-like; but, in the third, they are dentiform, and resemble the Dentalia. The whirls in the first division are contiguous; while, in the second and third, they are detached.

The N. pompilius, when bisected, exhibits in an eminent degree the pearly concamerations for which this genus is distinguished. The inbabitants of the East often convert fine specimens of the above species into drinking cups; they carve the surface into various devices and ornaments, and also frequently remove the outer coating entirely, by which the beautiful pearly appearance of the shell becomes visible. The umbilicated varieties of this species are rare.

The size of the Nautili differs exceedingly; some are so small as only to be defined by the microscope.

Some species of this genus are found adhering to coral rocks; the N. siphunculus is often found on the coral reefs on the Sicilian shores.

The American and Indian oceans, and the Mediterranean, Adriatic, and Red seas, produce some of the species 
of the Nautili; but by far the greater number are found on the British, and most of the European coasts.

\section{NAUTILUS-Sailor.}

Division I.-Spiral, with contiguous whirls. Pompilius-Great-chambered. Scrobiculatus-Sunken-spire. *Lacustris-Lake.

Minute or Microscopic Shells.

Calcar-Spur.

*Rotatus-Wheel.

* Lævigatulus-Smooth.

*Depressulus-Compressed.

${ }^{*}$ Crispus-Keel-edged.

*Beccarii-Beccaria's.
Balthicus-Baltic.

*Crassulus-Strong.

*Umbilicatulus-Umbilicated.

*Lobatulus-Lobed.

Rugosus-Rugged.

Umbilicatus-Oblique-jointed.

Division II.-Spiral, with detached whirls.

Spirula-Ram's-horn.

Minute Shells.

Spengleri-Spengler's. Unguiculatus-Nail-shap'd.

Division III.-Elongated and almost straight.

Minute.

*Semilituus-Half-crozier. * *Spinulosus-Spinous-jointed.

Lituus-Crozier.

*Sub-arcuatus-Sub-arcuated.

* Carinatulus-Keeled.

*Bicarinatus-Bicarinated.

*Obliquus-Obliquely-striated. Fascia-Banded.

Raphanistrum-Twelve-striated. Inæqualis-Unequal.

Raphanus-Seventeen-striated. Siphunculus-Piped.

*Costatus-Ribbed.

Granum-Eight-striated.

*Radicula-Bulbous-jointed.
*Legumen-Pod.

*Linearis-Linear.

*Rectus_Straight. 


\section{CONUS.-CONE.}

Animal-a Limax: Shell univalve, convolute, turbinate; aperture effuse, longitudinal, linear, without teeth, entire at the base; pillar smooth.

OF this beautiful and valuable gerius, only one hundred and sixty-five are described as distinct species; but that number is certainly less than the real amount.

The Cones are very similar in form, their principal differences consisting in the colouring, marking, and banding; yet, form sometimes assists their arrangement into classes: for instance, those which have a subtruncated base, as the C. marmoreus and C. imperialis, constitute one division. Another division is formed of those species which are pyriform and rounded at the base, and have a thick structure: of these, the $\mathbf{C}$. betulinus and $\mathbf{C}$. glaucus may be adduced as examples. The $\mathbf{C}$. textile and $\mathbf{C}$. aulicus are elongated and rounded at the base, and are characteristic of the third division: they somewhat resemble the C. tulipa, C. geographicus, and C. bullatus, but these are distinguished by having a wider aperture, and being more inflated.

Most of the Cones have a smooth surface, and bear a high natural polish; but some, as the C. nussatella and C. granulatus, are covered with granulated transverse striæ, and eren globular tubercles.

No other genus can vie with the Conus for the beauty and diversity of the colouring and marking; and none perhaps holds so important a station in collections. The lines on the C. literatus often resemble Hebrew, Greek, or Arabic characters; and the $\mathbf{C}$. ebræus exhibits similar appearances. In other species the colours are arranged into different shades of cloudings, veins, marblings, dots, stripes, bands, or reticulations. 
Among the rarities may be enumerated the $\mathrm{C}$. ammiralis or admiral cone, the vice-admirals, guinea-admirals, and the varieties of the zebra cones from the South Seas; most of which, when fine, are frequently estimated at from one to ten guineas. But this price appears trifling when compared with the value of the C. gloria-maris; which, incredible as it may appear, was estimated at one hundred guineas. The following are also considered rare and beattiful: the C. aurisiacus, C. glaucus, C. nobilis, and a variety of C. quercinus, which has been found at the Friendly Islands, surrounded with an elevated girdle.

The far greater number of species are found in the Indian ocean; some are brought from the shores of Africa and America; and others from the Sontl Seas.

\section{CONUS-Cone.}

\section{Division I.-Spire subtruncated.}

\section{FAMILY 1.-Spire coronated.}

Marmoreus-Marbled.

Nocturnus-Night.

Nicobaricus-Nicobar.

Arachnoideus-Spider-web.
Zonatus-Zoned.

Imperialis-Imperial.

Fuscatus-Clouded.

Candidus-White.

Family 2.-Spire plain or channelled.

$\begin{array}{ll}\text { Literatus-Lettered. } & \text { Mustelinus-Weasel. } \\ \text { Eburneus-Square-spotted. } & \text { Leopardus-Leopard. } \\ \text { Tessellatus-Mosaic. } & \text { Hyæna-Hyena. } \\ \text { Generalis-General. } & \text { Miles-Soldier. } \\ \text { Monile-Necklace. } & \text { Centurio-Centurion. } \\ \text { Canaliculatus_Grooved. } & \text { Fusiformis-Fusiform. } \\ \text { Radiatus-Radiated. } & \text { Spurius_Spurious. } \\ \text { Virgo-Virgin. } & \text { Leoninus-Lion. } \\ \text { Capitaneus-Captain. } & \text { Characteristicus-Arabic. } \\ \text { Chemnitzi-Chemnitz's. } & \text { Cærulescens-Bhe. } \\ & \text { Zebra-Zebra. } \\ & \text { E 3 }\end{array}$


Division II.-Pyriform, rounded at the base.

FamiLY I.-Spire coronated.

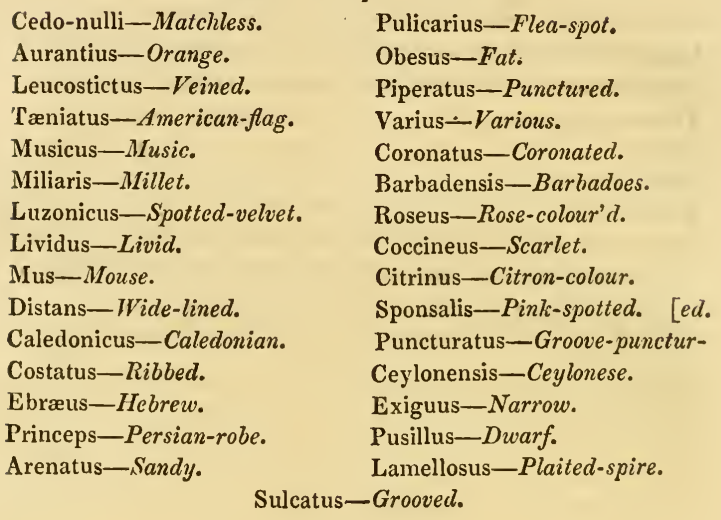

Family 2,-Spire plain or channelled.

Janus-Janus.

Guinaicus-Guinea.

Fulmineus-Lightning.

Lorenzianus-Lorenza's.

Amadis-Amadis.

Acuminatus-Sharp-pointed.

Thomæ-St. Oma's.

Ammiralis-Admiral.

Archithalassus-Granulated.

Vitulinus-Spotted.

Planorbis-Depressed-spire.

Senator-Senator.

Catus-Cat.

Nobilis-Noble.

Siamensis-Siamese.

Genuanus-Gartered.
Suratensis-Surat.

Monachus-Monk.

Ranunculus-Ranunculus.

Anemone-Anemone.

Achatinus-Tulip.

Rusticus-Rustic.

Nisus-Brown-throated.

Coffeæ-Coffee.

Vittatus-Ribbon.

Classarius-Sailor.

Mercator-Net-work.

Betulinus-Birch-bark.

Figulinus-Brown-banded.

Inornatus-Naked.

Quercinus-Box-wood.

Lineatus-Lineated.

Papilionaceus-Butterfy's-wing. Eques-Equestrian.

Fluctifer-Prometheus.

Ermineus-Ermine.

Glaucus-Brownish.

Vexillum-Flag. 
Testudinarius-Turtle.

Venulatus-Veined.

Namocanus-Ashwood.

Stercus-muscarum-Fly-spot-

Cancellatus-Cancellated.

Portoricanus-Porto Rico.

Tinianus-Red-colour'd.

Taitensis-Blackish-violet.

Scabriusculus-Scabrous.

Rattus-Rat.

Jamaicensis-Three-banded.
Mediterraneus-Olive-clouled.

Puncticulatus-Red-dotted.

Mauritianus-Mauritian.

Verrucosus-Warted.

Columba-Dove.

Madurensis-Green-cross.

Jaspideus-Jasper.

Japonicus-Orange-mottled.

Mindanus-White-mottled.

Festivus-Festive.

Reticulatus-Netted.

Iron-colour'd.

\section{Division III.-Elongated and rounded at the B.ise.}

Clavus-Yellow-veined.

Gradatus-Stepped.

Aureus-Golden.

Circumcisus-Truncated.

Terebellum-Chocolate.

Australis_Southern.

Lævis-Smooth.

Ochroleucus-Yellowish.

Strigatus-Pale-violet.

Mitratus-Mitre.

Glans-Acorn.

Tenellus-Delicate.

Nussatella-Nussatella.

Granulatus-Grained.

Fusus-Spindle.

Aurisiacus-Orange.

Terebra-Whimble.

Raphanus-Radish.
Adansoni-Adanson's.

Augur-Augur.

Magus-Magician.

Striatus-Striated.

Gubernator-Pilot.

Gloria-maris-Glory of the sea.

Pyramidalis-Pyramid.

Textile-Embroidered.

Abbas-Abbot.

Archiepiscopus-Archbishop.

Canonicus-Canonical.

Episcopus-Bishop.

Prælatus-Prelate.

Pennaceus-Plumose.

Rubiginosus-Orange-brown.

Omaria-Pearl-brown.

Aulicus-Brunette.

Elongatus-Lengthenerl.

Division IV.-Ventricose, with a wide aperture.

Spectrum-Spectre.

Informis-Misshapen.

Ventricosus-Ventricose.

Bullatus-Buböle.
Timorensis-Timor.

Nimbosus-Rainy.

Tulipa-Tulip.

Geographicus-Geographic. 


\section{CYPRÆA.-Cowry OR GowrIE.}

Animal-a Slug: Shell univalve, involute, subovate, smooth, obtuse at each end: aperture effuse, linear, extending the whole length of the shell, and toothed on each side.

THIS beautiful genus contains seventy-three species, but these may be subdivided into more than a hundred varieties. The shells when arrived at muturity have their two lips always beset with strong articulate teeth, which is the characteristic mark of the genus.

The Cyprææ, though very similar in form, possess sufficient distinctions to constitute six divisions: the first includes those that have a manifest spire, such as the $\mathrm{C}$. Arabica, C. amethystea (the young of C. Arabica), C. exanthema, C. plumbea (the young of C. exanthema), and C. mappa. Those, on the contrary, which are without a manifest spire, form the second division; as the C. caputserpentis (snake's head), and C. Mauritiana. The third division is composed of the umbilicated or perforated varieties; such as the C. ziczac, C. asellus, \&c. Those species which are marginated form the fourth class: viz. the C. moneta, and C. annulus, \&c. The C. moneta is fished up by the negro women, three days before or after full moon, and transported into Bengal, Siam, America, and the adjacent islands; where it is used by the native blacks as a substitute for money. The fifth division is composed of those species which have their backs wrinkled, such as the C. oniscus, C. sulcata, \&c. And the sixth, of such as are beaked at the extremities, as for example the C. nucleus, C. staphylea, \&c.

Most of the Cowries are smooth glossy shells, of exquisite brilliancy of colour, and elegantly marked with dots, 
zigzag lines, undulations, streaks, \&c.; which are beautifully exemplified in the C. mappa, the C. argus, and the $\mathrm{C}$. testudinaria. To these may be added the $\mathrm{C}$. vitellus, the C. carneola, the C. talpa, and others of the like description. Some of the species, however, have but little colouring, and have their surfaces covered with small globular tuberculations or warts, as the C. pustulata.

One of the largest and most valuable Cowries is the C. aurora, or orange cowry, which is found, though very rarely, at the Friendly Isles. Of the smaller cowries, the C. stolida and the C. pustulata are considered rare.

The greater proportion of the Cyprææ are found in the Indian ocean; many, however, come from the American, African, and Mediterranean shores; some also from the South seas.

\section{CYPRÆA-Cowry.}

Division I.-SPIRE not Quite concealed.

$\begin{array}{ll}\text { Exanthema-False-argus. } & \text { Carneola-Flesh-colour'd. } \\ \text { Mappa-Map. } & \text { Talpa-Mole. } \\ \text { Arabica-Arabic. } & \text { Lurida-Lurid. } \\ \text { Histrio-Harlequin. } & \text { Vanelli_Saffron-throated. } \\ \text { Argus-Argus. } & \text { Lota-White. } \\ \text { Testudinaria-Tortoise-shell. } & \text { Guttata-Dotted. } \\ \text { Stercoraria-Livid. } & \text { Sanguinolenta-Sanguine. } \\ \text { Aurora-Orange. } & \text { Undata-Waved. } \\ & \text { Teres-Long. }\end{array}$

Division II.-Obtuse, SPIRE QUite CONCE.Aled.

Achatina-Agate.

Pantherina-Panther.

Caput-serpentis-Snake's-head. Lynx-Lynx.

Mauritiana-Blackish-brown. Felina-Feline.

Vitellus-White-spotted.

Cinerea-Ash-colour'd.

Mus-Mouse.

Isabella-Yellow.

Tigris-Tiger.

Cylindrica-Cylindric.

Indica-Green-spotted. 


\section{Division III.-Umbilicated.}

Onyx-Onyx.

Subflava-Yellowish. Clandestina-Clandestine.

Succincta-Banded.

Ziczac-Ziczac.

Zonata-Zoned.
Hirundo-Swallow.

Ursellus-Brown-spot.

Lutea-Yellow.

Asellus-Three-banded.

Errones-Olive-mottled.

Pyrum-Pear.

Punctata-Dotted.

Division IV.-With the Margin thickened.

Moneta-Money.

Annulus-Annular.

Caurica-Thick-edg'd.

Dracæna-Angular-marked.

Cruenta-Ferruginous.

Cribraria-Umbilicated.

Erosa-Bordered.

Flaveola-Ochreous.

Spurca-Narrow-margin'd.
Stolida-Square-spotted.

Tabescens-Slender.

Helvola-Star.

Angustata-Narrow.

Ocellata-Eyed.

Albuginosa-Bird's-eye.

Poraria-White-spot.

Gangranosa-Gangrene.

Tessellata-Mosaic.

Division V.-WITh THE BACKS RIBBED, WRINKLED, OR TUBERCULATED.

Oniscus-Woodlouse.

Europea-European.

Sulcata-Sulcated.

Madagascariensis-Madagascar.

Aperta-Wide-mouth'd.

Pustulata-Pustulated.

Division VI.-Beaked at the extremities.

FaMiLY 1.-Having raised dots on the back.

Nucleus-Wrinkled. Staphylea-Groove-back' $d$.

Cicercula-Vetch.

Family 2.-With the back smooth.

Margarita-Pearl.

Globulus-Globular. 


\section{BULLA.-Dipper or Bubble.}

Animal-a Limax: Shell univalve, convolute, unarmed with teeth: aperture a little straitened, oblong, longitudinal, very entire at the base; pillar oblique, smooth.

THIS genus, which contains fifty-five species, is in some instances so nearly allied to the preceding, that much caution is necessary to prevent confusion in the classification; so great indeed is the difficulty of distinguishing the young shells of the Bulla and Cypræa, that the two genera have been intermixed by some authors. However, one grand mark of distinction in this genus is, that, in whatever stage of growth its species are found, they never have teeth on both their lips, the pillar-lip being invariably free from any appearance of denticulations; while in the Cyprææ, both the pillar and outer lips are crenated with very articulate and prominent teeth. There is also a greater variety of form in the Bullæ than in the Cyprææ. Some species, as the B. volva, or weaver's shuttle, are of an elongated form, having the length much increased by two produced beaks.

The next variation of form is discernible in the B. ovum, or poached egg, of which there are two varieties: the common, from Amboyna, is white without, and yellow within; the rarer, from the Friendly Isles, is white without, and pink within. These shells are less beaked and more gibbous than the B. volva, and lead into the following orbicular species, viz. the B. naucum, B. physis, B. ampulla, \&c. These are without teeth, and rather umbilicated.

The B.terebellum is an exception to the general form of the Bullæ, its shape being remarkably long and slender, and resembling a lengthened olive. 
Some of the Bullæ, as the B. ficus and B. rapa, are very similar to the genus Murex: the latter species is esteemed a rarity; the former, on the contrary, is common, and very much resembles the shape of a fig.

The B. zebra, B. fasciata, B. achatina, and other similar species, are land shells; in form, they are nearly allied to the genus Helix. It is remarkable, that the animals which inhabit them are oviparous. The reverse varieties, that is to say, those having their whirls or spires twisted contrary to the ustal direction, and having, at the same time, their mouths placed on the opposite side, are highly valued. The B. purpurea inhabits Africa, and is found in rice fields.

Some species of this genus are remarkable for the brittleness and lightness of their shells; such are the B. velum, R. amplustre, \&c.

The inhabitant of the B. lignaria, and, in all probability, of many other species, is furnished with an organ called a gizzard, of a testaceous nature.

The different species of this genus are to be found in the Mediterranean, African, American, Indian, European, and Northern seas.

The Bulla, probably, derives its name from some of the lesser species resembling a dew-drop, or bubble of water.

\section{BULLA-Dipper.}

Division I.-Shell Resembling the cyprata genus, but TOOTHED ON THE OUTER LIP ONLY.

$\begin{array}{ll}\text { Ovum-Poached-egg. } & \text { Nucleus-Wrinkled. } \\ \text { Imperialis-Crunteled } & \text { Verrucosa-Warty. }\end{array}$

Division II.-Shell oblong, beaked at the ends.

Volva-Weaver's-shuttle. Secale-Rye-shaped.

Lepida_Orange. Spelta-Oblong.

Birostris-Lesser. Gibbosa-Belted. 
Division III.-Shell thin, gibBous, ANd APERture LARGE.

Family 1.-Apex generally umbilicated and without a spire.

Naucum-Sea-nut.

*Aperta-Wide.

*Catena-Chain.

*Plumula_F'eather.

*Hydatis-Paper.

Ampulla-Pewet's-egg.
Amygdalus-Almond.

* Lignaria-Broun-striated.

Pectinata-Pectinated.

Soluta-Unsealed.

*Akera-Elastic.

Cylindrica-Cylindric.

Velum-White-banded.

Shells Minute.

*Cylindracea-Cylindrical. *Retusa-Blunt.

*Umbilicata-Umbilicated. *Obtusa_Obtuse.

FaMILY 2.-Having a spire.

Physis-Striped.

Zonata-Zoned.

Amplustre-Banded.

Undulata-Undulated.

Scabra-Rough.

Division IV.-Shell pyrifori, with produced beak.

Ficus-Fig.

Pyrum-Pear.

Rapa-Turnip-shap'd.

Canaliculata-Channelled.'

Division V.-Shell generally thin, SPIRE Prominent, AND BODY WHIRL INFLATED.

Voluta-Volute.

Strigata-Yellow-strealed.

Dominicensis-Nine-whirl'd.

Crassula-Reversed.

Striatula-Striated.

*Fontinalis-Fresh-water.

Exarata-Wrinkled.

Truncata-Truncated.

*Rivalis-River.

Priamus-Priam.

*Hypnorum-Slender.

Zebra-Zebra.

Gelatinosa-Gelatinous.

Achatina-Broad-strip'd.

Virginea-Ribbon.

Purpurea-Purple-mouth'd.

Fasciata-Banded.

Sinistrorsa-Great-revers'd.

Division VI.-Shell cylindrical, with a subulate spire. AND TRUNCATE Base.

Terebellum-Awl-shaped. 


\section{VOLUTA.-Volute OR Wreath.}

Animal-a Limax: Shell one-celled, spiral; aperturewithout a beak, and somewhat effuse; pillar twisted or plaited, generally without lips or perforátion.

THE one hundred and ninety-seven species of this genus are more or less celebrated for their beauty or scarcity; and are easily distinguished from all other Univalves, by their having several teeth or plaits on the columella or pillar-lip. In some species, the number of teeth amounts only to four or five; but, in others, as in the Olives, it is unlimited, and frequently extends to as many as thirty or forty, when they are much smaller and less articulate.

The Volutes are generally of a smooth and polished surface; among the exceptions may be mentioned the V.turbinellus, V. ceramica, V. capitellum, and many of the mitres.

Among the innumerable varieties of the olives, the camp or panama (V. porphyrea) is most conspicuous, not only for the peculiarity of its markings, but also for the considerable magnitude it attains. The rest of the species of the olives, as the V.oliva, V. ispidula, and V. utriculus, \&c. although not remarkable for their scarcity, are much admired for their beauty and variety.

Some of the rarer Volutes are the produce of the land, and are curiously distinguished from the rest of the genus by having their mouths shaped like an ear; such are the V. auris-Midæ, V. auris-Sileni, V. auris-Judæ, V. aurisMalchi, \&c. The three first are found in the marshy woods and swamps of India, and are numbered among the rarities of the genus. The last is an inhabitant of New Caledonia. 
The fusiform or spindle-shaped volutes constitute a large portion of the genus, and are usually known by the name of mitres; some of them are very elegantly formed and finely tinted in their colouring. The species most worthy of remark are the $\mathrm{V}$. patriarchalis, the $\mathrm{V}$. pertusa, V. papalis, and V. episcopalis or bishop's mitre, which is frequently found in India; the inhabitant or fish is said to be of a poisonous nature, and to wound with a kind of pointed trunk those who touch it. The natives of the island of Tanna fix these shells in handles, and use them as hatchets. Among the rest of the elongated form may be enumerated the V. sanguisuga, V. caffra, V. vulpecula, and $\mathrm{V}$. plicaria, some of which are considered rare.

The V. musica, or music shell, though not rare, is very interesting, from the circumstance of having its markings arranged in parallel lines, like the lines or a stave in music, upon which are placed small dots or punctures, in exact resemblance of the notes and other characters used in music. The wild music or bat Volute (V. vespertilio) is a curious variety of the above; as is also the V. ebræa, which is esteemed a rarity.

Among the more beautiful species of the Volutes, are the $\mathrm{V}$. vexillum or orange flag Volute, V. imperialis, V. Pacifica, the V. lapponica, V. scapha, and V. Magellanica.

The species of Volutes call Melons are mostly of a large size; and some of them, as the V. Ethiopica or Ethiopian crown, and its varieties, have their whirls or spires surrounded with elevated hollow spines, forming a perfect coronation or thorny crown: most of this division are papillary at the tip.

The heavy and angulated turnips are worthy of notice among the Volutes, not only on account of their great size, but for their excessive weight, which, in comparison to most other shells, is really immense.

The different species of Volutes are found in various 
parts of the world; but, in all probability, the Indian seas produce the most; though the Atlantic, Pacific, Northern, and European oceans, also yield their supplies.

\section{VOLUTA-Volute.}

\section{Division I.-Shell ovate, with the aperture gene- RALLY EAR-SHAPED AND ENTIRE.}

Auris-Midæ-Midas'-ear. Aures-Judæ-Judas'-ear. Australis-New Holland. Auris-Malchi-Malchus'-ear. Glabra-Smooth. Auris-Sileni-Silenus'-ear. Fasciata-Banded.
Auris-virginis-Virgin's-ear. Auris-vulpina-Fox's-ear. Auris-cati-Cat's-ear. *Tornatilis-Double-banded. Flammea-Variegated.

Solidula-Strong.

Livida-Livid.

Coffea-Coffee-colour.

\section{Minute Shells.}

Minuta-Minute.

Flava-Yellow.

*Denticulata-Toothed. Triplicata-Three-tooth'd. Pusilla_Small-oval.

*Bidentata-Double-tooth'd.
*Alba-White.

*Pellucida-Pellucid.

*Unidentata-Single-tooth'd.

*Interstincta-Divided.

*Insculpta-Engraved.

*Plicatula-Plaited.

*Ambigua-Doubtful.

Division II.-Shell ovate, smooth, outer Margin THICKENED, APERTURE NEARLY ENTIRE.

Elegans-Elegant.

*Pallida-Pallid.

Exilis-Brown-banded.

Monilis-Necklace.

Miliaria-Millet.

Guttata-Dotted.

Marginata_Margined.
Faba-Bean.

Strigata-Wave-striped.

Prunum-Bluish-grey.

Chemnitzii-Chemnitz's.

Glabella-Polished.

Picta-Painted.

Castanea-Chesnut. 
Division III.-Shell ovate, SMooth, SPIRE flat, APERTURE EFFUSE AND LINEAR.

Porcellana-Porcelain.

Persicula-Red-spotted.

Cingulata-Red-lined.
Bullata-Bubble.

*Lævis—Smooth.

*Catenata-Chain-spotted.

Division IV.-Shell sub-cylindrical, enamelled, aNd EMARGINATED.

FaMily 1.-Spire rather obtuse.

Porphyrea-Porphyry. Incrassata-Thickened.

Erythrostoma-Orange-mouthid. Pinguis-Quaker.

Oliva-Olive.

Tigrina-Tiger.

Ventricosa-Ventricose.

Carneola-Carnelian.

Utriculus-Bottle-shaped.

Micans-Little.

FAMILx 2.-Spire prôminent or conical.

Cruenta-Orange-throat.

Annulata-Ringed.

Gibbosa-Gibbous.

Ispidula-Enamelled.

Hiatula-Gaping.
Ampla-Large.

Nivea-Snowy.

Jaspidea-Jasper.

Ancilla-Damsel.

Nitidula-Delicate.

Oryza-Rice.

Division V.-Shell fusiform, generally Striated or RIBBED, EITHER LONGITUDINALLY OR TRANSVERSELY.

FamiLY 1. - Spire less than half the length of the shell.

Crenulata-Crenulated.

Fenestrata-Eight-plaited.

Dactylus-Six-plaited.

Conus-Conic.

Texturata-Four-plaited.

Microzonias-White-banded. Tringa-Decorticated.

Fissurata-Straw-colour'd.

Barbadensis-Striped.

Spadicea-Five-plaited.

Decussata-Decussated.

Variegata-Variegated.

Caffra-Caffre.
Leucozonias-White-striped.

Morio-Tawny.

Aurantia-Orange.

Vitulina-White-banded.

Olivaria-Two-banded.

Nubila-Clouded.

Pertusa-Punctured.

Spiralis_Spiral.

Patriarchalis-Patriarch.

Muriculata-Walled.

Paupercula-Zebra.

Pica-Magpie.

Ferrugata-Bellied. 
FAMILY 2.-Spire half the length of the shell.

Cornicula-Horn-colour. Rugosa-Rugose.

Schroeteri-Schroeter's.

Crenifera-Crenated.

Scabricula-Roughly-striated.

Ruffina-Reddish-yellow.

Vulpecula-Foxy.

Castellaris-Chequered.

Subdivisa-Subdivided.

Melongena-Fine-ribbed.

Plicaria-Folded.
Scutulata-Scutcheon.

Nigra-Black.

Casta-Brown-banded.

Serpentina-Serpent.

Digitalis-Fingered.

Episcopalis-Mitre.

Papalis--Pope.

Thiara-Thiara.

Coronata-Crown.

Shell less than half an inch in length.

Maculosa-Spotted.

Discors-Discordant.

Biplicata-Two-plaited.

Striata-Striated.

Turricula-Tower.

Lævigata-Smooth.

Lineata-White-lined.

Ocellata-Eyed.

Sulcata-Sulcated.

Nasuta-Black-spotted.

\section{Marmorea-Marbled.}

FAMiLY 3.-Spire more than half the length of the shell.

Acuminata-Sharp-pointed. Nodulosa-Nodulous.

Virgo-Virgin.

Sanguisuga-Leech.

Filaris-Narrow.

Polygona-Polygonal.

Filosa-Threaded.

Tæniata-Ribbon.

Clathrus-Cancellated.

Cruentata-Knotty-ribbed.

Exasperata-Granulous.

Turrita-Turreted.

Costata-Ribbed.

Acus-Needle.

Granosa-Grained.

Abbatis-Abbot.

Division VI.-Shell small, thick, strong, having the OUTER LIP DENTICULATED, AND RATHER ANGULAR.

Mercatoria-Clouded.

Ziervogelii-Thick-lipped.

Rustica-Rustic.
Torva-Rough.

Mendicaria-Black and white.

Nana-Dwarf. 


\section{Division VII.-Shell emarginate, effuse, and spire} RATHER PAPILLARY.

Family 1.-Whirls nodulous or plain.

Musica-Music.

Virescens-Greenish.

Plicata-Plaited.

Ebræa-Hebrew-character.

Fusiformis-Spindle-shaped.

Flavicans-Yellowish.

Nivosa-Snow-spotted.

Vexillum-Banner.

Lapponica-Spotted.

Junonia-Peacock.
Harpa-Lyre.

Magnifica-Magnificent.

Volva-Whitish.

Undulata-Undulated.

Magellanica-Magellanic.

Rupestris-Lightning.

Pacifica-Pacific.

Angulata-Angular.

Scapha-Clouded.

Colocynthis-Wide-mouthed.

FAMILY 2,-Whirls crowned with spines.

Imperialis-Imperial. Vespertilio-Bat.

Division VIII.-Shell ventricose, and the summit of THE SPIRE PAPILLARY.

Family 1.- Spire coronated or nodulous.

Ethiopica-Ethiopic.

Diadema-Diadem.
Tessellata-Tessellated.

Corona-Ducal-crown.

Fayily 2.-Spire channelled.

Olla-Melon.

Rubiginosa-Ochrecus.
Cymbium-Cup-like.

Neptuni-Neptune's.

FaMiLy 3.-Spire truncated.

Porcina-Keel-margin.

FAMILY 4.-Shell formed by one broad whirl.

Glans-Reddish-yellow. Navicula-Gondola.

FaMiLy 5.-Spire nearly buried in the body whirl.

Melo-Melon.

Division IX.-Shell Nearly entire, longitudinally

OR TRANSVERSELY RIBBED AND SUBUMBILICATED.

Reticulata-Reticulated. Cancellata-Latticed. 
Nassa-Ribbed.

Fusca-Tawny.

Nucea-Nut.

Division X.-Shell spinous, or RUgGed and nodulous.

Turbinellus-Turbinated. Muricata-Prickly.

Capitellum-Ridged. Ceramica-Horred.

Rhinoceros-Rhinoceros. Globosa-Globose.

Division XI.-Shell with a somewhat produced BEAK.

Pyrum-Pear-shaped. Gravis-Solid.

Scolymus-Artichoke.

BUCCINUM.-WHELK.

Animal-a Limax: Shell univalve, spiral, gibbous, aperture ovate, terminating in a short canal, leaning to the right, with a retuse beak or projection; pillar-lip expanded.

THIS genus comprises one hundred and sixty-one species, which are remarkable for their great beauty and variety. The Buccinum may be distinguished from the $G$. murex, (which it closely resembles), by its beak or canal being usually much shorter, and inclining to the right instead of the left; it is also generally more gibbous, which is particularly the case with those species called tuns and helmets. The tuns are for the most part of a brittle and light fabric, and although some of them grow to a large size, yet even then they retain their characteristic fragility and thinness.

The B. dolium, B. perdix, and the B. galea are the most common species; the latter of which sometimes exceeds ten inches in diameter. 
The helmets, which compose the fourth division, are nearly allied to the tuns, but are distinguished by having both their lips, with few exceptions, crenated with strong articulated teeth; they are also covered with prominent protuberances or kuobs. Among the species of this description may be enumerated the B. plicatum, B. cornutum, and B. rufum, which is remarkable for its nodulous belts, and the fiery-red colour of its mouth.

The seventh division contains the Harps, which are considered the most valuable and beautiful species of the genus: among these may be particularized the B. harpa and B. costatum, the latter is commonly called the Many-ridged Harp, and surpasses all the other varieties in elegance and rarity. It is found at the Isle of France, and has been sold for as large a sum as fifty pounds. Of the Scoops, which form the eighth division, the most common species are the B. patulum and B. haustrum : there are two varieties of the B. Persicum, both of which are considered rare, when in fine condition.

Many species of the tenth division resemble in form the B. undatum or common English whelk, the inhabitant of which is often eaten. The B. spiratum hasits whirls channelled or spirally grooved; and the animals of B. scala and B. lapillus yield a fine durable purple die. The Buccinum bezoar has its whirls surmounted with rows of foliations; and is, therefore, generally called the Foliated Bulb.

The last division of Buccina is more distinct than any hitherto enumerated: it comprises those shells which are usually known by the name of needles, on account of their sharp, lengthened, and spiral form; and, though by no means rare, they are often elegantly marked. The most common species is the B. maculatum or marline-spike, which sometimes exceeds nine inches in length: some of 
the other species, as the B. subulatum and B. crenulatum, are very beautiful.

The B. sinuatum and the B. virgineum are fresh water species.

The African, American, Indian, European, and Southerm oceans produce the greater part of the species; many are found on the British shores; and also some few in the Mediterranean.

This genus derives its name from some of its species being formed like a trumpet.

\section{BUCCINUM-Whelk.}

Division I.-Shell inflated, kounded, thin, shightly TRANSPARENT AND BRITTLE.

FAMILY 1.-Aperture without teeth.

Olearium-Tun.

Galea-Brown.
Perdix-Partridge.

Dolium-Spotted.

Caudatum-Beaked.

Famiry 2.-Outer lip toothed.

Sulcosum-Flat-ribbed. Chinense-Chinese.

Division II.-Shell ovate, Ribbed, apertule Rather CONTRACTED, PILLAR-LIP THICKENED AND STRONGLY WRINKLED, AND OUTER LIP TOOTHED, THICKENED, AND MARGINATED.

Pomum-Thick-lipp'd. Ringens-Grinning.

Division III.-Shell with tuberculated belts or Ribs, PILLAR-LIP SPREAD, AND BEAK MUCH PRODUCED

AND REFLECTED.

Echinophorum-Tuberculated Nodosum-Belted.

Tuน.

Rugosum-Rugged. 
Division IV.-Shell with an exserted Reflected beak, PILLAR-LIP SPREAD, AND THE OUTEK LIP UNARMED OUTWARDLY.

FAMILY 1.-With the spire truncated, aperture rather linear, pillar-lip much spread, the pillar slightly wrinkled, and outer lip thickened.

Cornutum-Wrinkled Helmet. Flammeum-Triangular.

Plicatum-Plaited. Rufum-Red.

Tuberosum-Zic-zag. Testiculus-Purse.

FAMILY 2.-With the spire rather elevated, pillar-lip thinly spread, pillar slightly wrinkled, and outer lip thickened.

Decussatum-Decussated. Strigatum-Yellow-striped.

Areola-Draft-board. Saburon-Grey.

Abbreviatum-Shortened.

Fasily 3.-Resembling the second, except having the pillar-lip granulated.

Granulatum-Granulated. Undulatum-Undulated.

FAMILY 4.-Resembling the third, but having the pillar-lip granulated and wrinkled.

Inflatum-Inflated.

*Bilineatum-Smooth-net.

Tessellatum-Tessellated.

Cicatricosum-Cicatrix.

FAMILY 5.-With the pillar-lip smooth.

Recurvirostrum-Recurved bealt. Cassis-Helmet.

Division V.-Shell Resembling the Last division, but THE OUTER LIP, ON THE OUTSIDE, IS MURICATED

AT THE BASE.

Fanily 1.-With the spire short.

Erinaceus-Hedgehog. Fimbria-Bordered.

Biarmatum-Knobbed. Glaucum-Yellow.

Vibex-Agate.

Family 2.-With the spire elevated.

Papillosum-Prickly-lip.

Glans-Thread-girded.
Mutabile-Changeable.

Gibbum-Hunchbacked. 
Division VI.-Shell with the PIlidar-lip dilated aNd THICKENED, AND APERTURE WIDE.

Family 1.-With the pillar-lip much thickened and dilated. Arcularia-Broad-lipped. Verrucosum-Warty. Coronatum-Crowned. Gibbosulum-Gibbous. *Hepaticum-Small-knobb'd. Clathratum-Latticed. Pullus-Young. Thersites-Pale-olive. Niveum-Cancellated. Lima-Acuminated.

Family 2.-With the pillar-lip spread, but not very thick. Textum-Turreted. Plicatulum-Plaited. *Reticulatum-Reticulated. Piscatorium-Knobbed. *Ambiguum-Small-plaited. Mauritii-Six-toothed. *Macula-Spot-lipped. Armillatum-Brown. Stolatum-Brown-banded. Nitidulum-Thin-banded. Ventricosum-Ventricose.

Famil y 3.-Obtuse, convex, depressed, and smooth. Neriteum-Nerite-shaped.

Division VII.-Shell with longitudinally KeEled, MUCRONATED RIBS, PILLAR SMOOTH.

Harpa-Harp.

Crenatum-Crenated.

Cancellatum-Latticed-harp. Costatum-Many-ridged.

Division VIII.-Pillar-Lip appearing as IF worn FLAT, APERTURE VERY WIDE AND OPEN.

FAMILY 1.-Armed with a subulate tooth at the base. Monodan-One toothed Scoop. Narval-Unicorn. Imbricatum-Imbricated. Cingulatum- Belted. Crassilabrum-Thick-lipp'd. Rhinoceros-Smooth.

Family 2.-Without the tooth, and the outside striated. Haustrum-Scoop. Sertnm-Chesnut. Persicum-Persian. Vexillum-Flag.

Family 3.-With the outside tuberculated. Patulum-Wide-mouth'd. Hæmastoma-Red-lipped. Luteostomum-Pallid. Armigerum-Armed. Dentex-Toothed. 
Division IX.-Shell Witi SPIRE obliquely Recurved, APERTURE VERY LARGE, OUTER LIP REFLECTED, AND PILLAR-LIP WITH TWO OBSOLETE TEETH AT THE BASE.

Concholepas-Limpei-shap'd.

Division X.-Shell coarse, spire icute, aperture OVATE, PILLAR-LIP SMOOTH AND FLATTISH.

*Lapillus-Common Whelk. Varium-Varied.

*Undatum-Wave-ribbed. Ciliatum-Ciliated.

Solutum-Unequal-ribbed.

Porcatum-Rugged.

Papyraceum-Paper.

Otaheitense-Otaheite.

Glaciale-Keel-ridged.

Carinatum-Carinated.

Filosum-Threaded.
Sulcatum-Grooved.

Smaragdulus-Emerald.

Undosum-Undulated.

Affine-Brown-striped.

Fumosum-Smoky.

Tranquebaricum-Tranquebar.

Cruentatum-Red-spotted.

Pyrozonias-Double-streaked.

Versicolor-Lurid.

Lamellosum-Lamellar.

Lamellatum-Lamellated.

Crispatum-Wrinkled.

Division XI.-Shell strongly ribbed transversely.

Orbitum-Globose.

Scala-Broad-belted.

Indicum-Indian.

Division XII.-Shell sub-Globose, ponderous, APerTURE LARGE, PILLAR-LIP VERY THICK.

Plumbeum-Double-groov'd. Crassum-Thick.

Division XIII.-Shell with the PILlar abrupt and STRONGLY UMBILICATED.

Spiratum-Acute-spire.

Eburneum-Spotted.
Zeylanicum-Ceylon.

Glabratum-Glossy.

Division XIV.-Shells somewhat polished and Not ENUMERATED IN THE FORMER DIVISIONS.

Tigrinum-Tiger.

Turgitum-Red-spotted.

Scutulatum-Stieaked.
Testudineum-Tortoise-shell.

Cochlideum-Indented-spire.

Catarracta-Long-striped. 
Lævissimum-Polished.

Cyaneum-Blueish.

Læve-Smooth.
Igneum-Red-streaked.

Lyratum-Lyre.

Plumatum-Painted.

Minute Shells.

Glaberrimum-Smooth.

Exile-Slender.

Nucleus-Small.

Prærosum-Carious.

*Lineatum-Lineated.

Minimum-Lesser.

Division XV.-Shell ROUNdish, SPIRE FLAT, Whirls LAMELLATED OR SPINOUS, BEAK PRODUCED AND UMBILICATED, AND APERTURE LARGE.

Bezoar - Bezoar's.

Bulbosum-Bulbous.

Division XVI.-Shell turReted, subulate, and SLIGHTLY POLISHED.

F AMILY 1.-Whirls entire.

Maculatum-Spotted Needle. Succinctum-Girdled.

Oculatum-Oculated. Lanceatum-Lancet.

Subulatum-Awl-shap'd. Murinum-Mouse-colour'd.

Felinum-Cat.

Hastatum-Javelin.

Vittatum-Ribbon.

Sinuatum-Twisted.

Digitale-Bluish-banded.

Bifasciatum-Two-banded.

Concinnum-Belt-spotted.

Radiatum-Radiated.

Cinereum-Steel-grey.

Virgineum-Fresh-water.

*Acicula-Minute-pointed.

Family 2.-Whirls divided by a transverse line or furrow.

Crenulatum-Crenulated. Strigilatum-Strigilated.

Hecticum-Hectic.

Geminum-Divided.

Duplicatum-Double-whirl.

Proximatum-Glossy.

Acus-Needle.

Monile-Necklace.

Dimidiatum-Orange \& White.

Pertusum-Hollow-dotted. 


\section{STROMBUS.-Winged or CLAW-ShelL.}

Animal-a Limax: Shell univalve, spiral; aperture much dilated; the lip expanding, and produced into a groove leaning to the left.

-THE distinguishing character of this genus, of which there are forty-six species, consists in the position of its beak, which inclines to the left; but as the younger shells are sometimes wholly destitute of any beak, a confusion with many other genera is often difficult to be avoided.

The Strombi seem to have a propensity to extend their outer lip, either into the form of an expanded wing, hence called alatæ or winged shells, or to continue it into long and pointed claws: but these appearances are only manifest in adult shells.

The most prominent species of the division which has the lips terminated by claws, are the following: S. chiragra, S. scorpius, S. lambis, and S. millepeda. The number of claws in the different species varies from six to ten, but the S. pes-pelicani has only four. In some species they are nearly straight, and often smooth, while in others they are very much curved, and covered with waved nodules. The growth of these shells is worthy of notice. It has already been stated, that the very young shells have no appearance of claws, which first shew themselves in the form of short and open spouts; when the shells are farther advanced in growth, they assume the shape they are to retain, but are still thin, hollow, and imperfectly closed; and it is only in the adults that they become solid, and have a thick, strong, and horn-like appearance.

The S. oniscus, in the sixth division, is totally destitute of a winged termination; and the S. fasciatus, S. pugilis, 
and S. lentiginosus, in the second division, exhibit only faint indications of that character: but in the S. gallus, S. auris-Dianæ, S. latissimus, (a very rare species), and S. gigas, it is remarkably prominent. Some other species have nearly the same peculiarity: as the S. epidromis, the S. vittatus, S. canarium, \&c. These latter species never grow to any magnitude; but some of the former, as the $\mathbf{S}$. latissimus and $\mathrm{S}$. gigas, frequently attain a considerable size.

The S. luhuanus, S. gibberulus, \&c. have some of their whirls very gibbous, and on that account they are often called Pouter-alati. Many of these are extremely beautiful, having their mouths of a scarlet, pink, or orange colour, and the interior of their shells of a rich blue, purple, or yellow colour.

The turreted species, which constitute the shells of the fourth and fifth divisions, are distinguished into two classes: the one having a longitudinal fissure extending from the aperture to the summit; and the other, by having a lengthened spire, resembling the Murices. Of the latter division, the two varieties of the S. fusus are characteristic examples; one variety has a short subulate beak, but the other, usually called the long-beaked spindle, is much more tapering and delicate, and its beak, when perfect, is nearly as long as the rest of the shell. It comes from the Straits of Sunda, and is considered one of the great rarities in collections. Of the fifth division, the $\mathrm{S}$. tuberculatus; S. palustris, from the meadows or savannahs of the Indian ocean; and S. ater, from the fens of Amboyna -are sufficient examples: it may be observed, that the three last are land species, and are characterized by having their whirls more or less beset with sharp knobs or prickly spines.

The African, Indian, American, and European oceans 
produce many species of this genus; and the Mediterranean, Red, and Arctic seas, only a few.

\section{STROMBUS-Winged or Claw-shell.}

Division I.-Shell with Linear segments, or Claws at THE MARGIN OF THE OUTER LIP.

Chiragra-Devil's-claw.

Scorpius-Scorpion.

Lambis-Spider.

Millepeda-Millepede.
Purpureus-Purple-mouth.

Elongatus-Lengthened.

Truncatus-Truncated.

*Pes-pelicani-Pelican's-foot.

Division II.-Shell with the outer LiP MUCh EXPANDED.

FAMILY 1.-With the margin of the outer lip thickened or lobed.

Gigas-Giant.

Accipiter-Heavy.

Gallus-Plough.

Tricornis-Three-horn'd.

Pugilis-Thick-spin'd.

Fasciatus-Banded.

Lentiginosus-Pink-lipped.
Papilio-Butterfly.

Auris-Dianæ-Diana's-ear.

Pacifica-Pacific.

Granulatus-Granulated.

Polyfasciatus-Many-banded.

Luhuanus-Luhoe.

Canarium-Partridge.

FAMILY 2.-With the outer lip curved inwards.

Latissimus-Broad-winged. Laciniatus-Sinuated.

FaniLy 3.- Spire elevaied, and outer lip rounded and short. Vittatus-Ribbon. Epidromis-Mainsail. . Sulcatus-Sulcated.

Fasily 4.-With both lips pointed, and attached to the whirls of the spire.

Marginatus-Margined. Minimus-Least.

Accinctus-Girdled.

Division III.-Shell SMooth oR PLAITED, oUter LIP STRIATED WITHIN, AND BUT SLIGHTLY EXPANDED.

Gibberulus-Pouter.

Urceus-Pitcher. 
Erythrinus-Nodulous. Samar-Samar.

Dentatus-Toothed.

Division IV.-Shell turReted, with a longitudinal FISSURE EXTENDING FROM THE APERTURE

TO THE SUMMIT.

Fissus-Slit. Fissurella-Fissure.

Division V.-Shell turreted, with a very long spire. FAMILY 1.-The aperture ending in a long beak, and the outer lip toothed.

Fusus-Spindle. Unicornis-Unicorn.

FAMILY 2.-Without the beak, and the aperture not toothed.

Tuberculatus-Tuberculated. Auritus-Eared.

Palustris-Marsh. Lividus-Livid.

Ater-Black. *Costatus-Ribbed.

Division VI.-Shell obovate, with transverse noduI.OUS BELTS, PILLAR-LIP GRANULATED, AND THE OUTER LIP THICKENED AND TOOTHED WITHIN.

Oniscus-Wood-louse.

MUREX.-Rock or Trumpet-Shell.

Animal-a Limax: Shell univalve, spiral, rough, with membranaceous sutures; aperture oval, ending in an entire, straight, or slightly ascending canal.

THE most prominent character which distinguishes the one hundred and seventy-two species of the Murex from those of the two preceding genera, consists in the beak, which inclines neither to the right nor left, but is almost invariably straight and very much produced, sometimes turning a little upwards. 
The Murices are generally of an irregular form, arising from their surfaces being usually covered with spines, knobs, striæ, or foliations. One division is peculiar for the uncommon length of beak, which most of its species are remarked for; the principal is M.tribulus, of which there are two varieties, the common called the thorny woodcock, and the rarer, after the French, peigne de Venus, or Venus's comb, which is not only considered a rarity, but is perhaps one of the most elegant shells of the genus; it is most beautifully adorned with thin and delicate spines, disposed longitudinally in three regular rows. To this same division belong also the M. cornutus and M. brandaris; the former grows to a considerable size, and is by no means common.

The third division includes those species that have a much shorter beak, and are more foliated than spinous; such are the M. trunculus, M. pomum, and M. radix; the latter grows to a considerable size and is much valued; its shell is beset with numerous rows of frondose, black, undulate spines, which being contrasted with opaque-white renders it an object of great beauty. It also comprises those species which are commonly called Triplices, or more properly Purpuræ, as the animals inhabiting most of the shells of this division possess the property of affording a rich purple juice or liquid; from this circumstance the whole genus has by some authors been called Purpura. The shells have their sutures composed of crisped foliations and acute angular ramifications; among those best known are the pink and yellow-mouthed varieties of the M. saxatilis, which are exceedingly rare and beautiful. The number of rows in the foliated sutures differs considerably, some (as the M. ramosus, \&c.) have only three, the M. scorpio has four, the M. saxatilis five, and the M. radix has nine.

The next division is composed of the species that have 
their sutures thick, protuberant, and rounded; such are the M. rana, M. lampas, M. lotorium, and M. femorale; the outer lip of the latter shell is frequently imitated in the borders or rims of massy silver plate, hence called the gadroon border.

In the species of the sixth division the form is more abbreviated and gibbous, they are also more or less spinous, and without a manifest beak : as in the M. ricinus, M. hippocastanum, and the varieties of the $\mathbf{M}$. neritoideus; most of which have rows of black tubercles and spines; some having purple, and others yellow mouths.

The ninth division of Murices is composed of those shells which have a long, straight, subulate beak, and unarmed with spines: such are the M. colus, of which there are many large and beautiful varieties; M. Babylonius, \&c. The M. Babylonius, and the other towers, have a small fissure or incision on the extremity of the outer lip, close to the termination of the first whirl, a peculiarity solely confined to these species. The reverse variety of the M. ficus, called the M. perversus, is a very rare species. The M. antiquus is also sometimes reversed. The animal of the M. despectus is often eaten, but is more generally used as a bait for cod and ray. The M. Tritonis, which is an inhabitant of the Mediterranean, Indian, and South Seas, is used by the natives of New Zealand as a musical shell, and by the Africans and many nations of the east as a military horn. It sometimes exceeds two feet in length.

The shells of the last division are tapering and subulate, and have a short beak. Among them may be noticed the M. vertagus, M. aluco, \&c.

Of the rarer species may be mentioned the M. regius, M. prismaticus, M. stramineus, M. radix, and M. aruanus.

The numerous species and varieties of the Murices are from the following places: Pulo Condore, Guinea, Senegal, 
Straits of Magellan; the European, Northern, and Southern seas; India, the Mediterranean, Adriatic, and Atlantic.

This genus derives its name from many of its species being rough, like the sharp crags of a rock.

\section{MUREX-Rock or Trumpet-shell.}

Division I.-Shell spinous, with a produced beak.

FaMiLy 1.-With three varices.

Tribulus-Thorny Woodcock. Scolopax-Thorny Snipe.

Motacilla-Nightingale.

FAMILY 2.-With seven varices.

Cornutus-Horned Snipe. Brandaris-Short-beak'd Snipe.

Division II.-Shell with a produced beak similar to THE FIRST DIVISION, BUT NOT SPINOUS.

Haustellum-Snipe.

Spirillus-Blunt-tipped.

Division III.-Shell foliated, with a short beak.

FaMiLy 1.-With three varices.

Ramosus-Branched.

Foliatus-Foliated.

Lingua-Sheep's-tongue.

Tripterus-Subtriangular.

Triqueter-Three-warted.

Family 2.-With more than three varices.

Scorpio-Scorpion.

Rota-Wheel.

Saxatilis-Endive.

Trunculus-Tyrian-dye.

Rosarium-Rosary.

Pomum-Apple-shap'd.

Regius-Royal.
Miliaris-Scabrous.

Radix-Root.

Melanomathos-Black-spined.

Lamellosus-Lamellar.

Clathratus-Ribbed.

*Erinaceus-Rough-ridg'd.

Scala-Ladder.

Division IV.-Shell With thick PRotuberant ROUNDEU VARICES.

Family 1.-With two opposite varices.

Rana-Frog.

Crassus-Thick-frog. 
Spinosus-Spiny-frog.

*Gyrinus-Whirled.

Bufonius-Toad-shap'd.
Lampas-Granulated.

Scrobilator-Violet-throated. Reticularis-Reticulated.

FAMILY 2.-With two subalternate varices.

Argus-Argus.

Olearium-Oil-jar.

Rubecula-Footman.

Femorale-Triangular.

Lotorium-Angulated.

Pileare-Nodulous.
Candisatus-Mottled.

Maculosus-Spotted.

Spengleri-Spengler's.

Pyrum-Pear.

Clavator-Club-shap'd.

Caudatus-Caudated.

Dolarium-Narrow-belt.

FAMILY 3.-With a single varix.

Parthenopus-Tawny-yellow. Clandestinus-Double-lipp'd.

Cutaceus-Rough-skin. Lyratus-Lyre-shap'd.

Division V.-Shell with unequally gibbous Whirls, DECUSSATED RIBS, AND THE APERTURE SURROUNDED BY A THIN DILATED MEMBRANE.

Anus-Grimace Whelk. Mulus-Mule.

Division VI.-Shell sonewhat spinous, ANd Without A BEAK.

Ricinus-Spur.

Nodus-Chesmut.

Neritoideus-Mulberry.

Fimbriatus-Seal-skin.

Hystrix-Porcupine.

Mancinella-Mancinella.
Hippocastanum-Horse-chesnut.

Sacellum-Corded.

Nodatus-Knobbed.

Lacerus-Carinated.

Virgatus-Nodulous.

Senticosus-Cancellated.

Division VII.-Shell nodulous, or longitudinally PLAITED, WITH A SHORT BEAK.

Plicatus-Plaited.

Morbosus-Diseased.

Consul-Ventricose.
Undatus-Waved.

Fiscellum-Short-beak' d.

Dubius-Doubtful.

Fenestratus-Latticed. 
Division VIII.-Shell ovate, aperture wide, inner LIP THICKENED AND SPREAD, OUTER LIP THICK AND UNDULATED.

Stramineus-Straw-colour'd. Australis-Southern.

Division IX.-Sinell with a long, straight, subulate BEAK, UNARMED.

FAMILY 1.-Turreted, outer lip having a notch at the summit. Babylonius-Tower-nf-Babel. Virgineus-Virgin-tower. Clavatulus-Crowned-tower. Javanus-Javanese. Gibbosus-Gibbous.

Tornatus-White-tower.

Faminy 2.-With the column plaited.

Tulipa-Tulip.

Polygonus-Many-angled.

Nassa-Rough.

Infundibulum-Funnel-shap'd.

Amplustre-American-flag.

Lancea-Lanceolate.

Trapezium-Striped-tower.

Ocellatus-Eyed.

Craticulatus-Plaited.

Family 3.-With the outer lip entire, and the column smooth. Colus-Spindle [ated. Canaliculatus-Channelled.

Striatulus-Transversely-stri- Carica-Keeled.

Versicolor-Changeable. Perversus-Reversed.

Verrucosus-Warty.

Ternatanus-Ternate.

Aruanus-Aru-trumpet.

Pardalis-Leopard.

Tuba-Trumpet.

Maroccensis-Morocco.

Cariosus-Carious.

Division X.-Shell With the spire rather depressed, APERTURE DILATED, NEARLY THE LENGTH OF THE SHELL, AND BEAK SHORT.

Melongena-Open-mouth. Candidum-White.

Calcaratus-Browrish-white. Corona-Crowned.

Ficus-Fig-shap'd. Morio-Moor.

Spadiceum-Lineated. Pugilinus-Reddish-brown.

Unbilicatum-Umbilicated. Cochlidium-Brown-streaked.

Harpa-Harp. 
Division XI.-Shell oblong ventricose, aperture diLATED AND OVATE, SPIRE PRODUCED, AND BEAK SHORT.

*Antiquus-Antiquated. Magellanicus-Magellanic.

Norwegicus-Norwegian.

Fornicatus-Arched.

Despectus-Despised.

*Subantiquatus-Angulated.

Tritonis-Triten.

Nerei-Musical.

Vulpinus-Fox.

Pusio-Wreath.

*Corneus-Slender-horn.

Lineatus-Lined.

Lignarius-Woody.

Syracusanus-Syracuse.

Perron-Shelving.

Prismaticus-Prismatic.
*Bamffius-Bamff.

*Gracilis-Elegant.

* Attenuatus-Lengthened.

*Nebula-Clouded.

* Costatus-Ribbed.

*Proximus-Many-ribbed.

* Septangularis-Seven-sided.

*Turricula-Turreted.

*Rufus-Red.

*Sinuosus-Sinuated.

*Linearis-Lineated.

*Purpureus-Purple.

*.Muricatus-Thorny.

*Minutissimus-Very-small.

Arenosus-Sea-sand.

Scriptus-Written.

Division XII.-Turreted and subulate, with a very SHORT BEAK.

Obeliscus-Chinese-obelisk.

Vertagus-Curved-beak.

Plicatulus-White-plaited.

Aluco-Caterpillar.

Tuberosus-Knobbed.

Adansoni-Adanson's.

Clava-Club-shap'd.

Uncinatus-Grapling.

Atratıs-Blackish.

Alucoides-Marbled.

Ebeninus-Deep-black.

Fuscatus-Clouded.

Torulosus-Ringed.
Radula-Rayed.

Marginatus-Margined.

Serratus-Serrated.

Asper-Rough-grain'd.

Granulatus-Grained.

Sulcatus-Grooved.

Literatus-Lettered.

Hexagonus-Six-ribbed.

*Reticulatus-Reticulated.

*Tubercularis-Tuberculated.

*Adversus-Left-handed.

*Subulatus-Awl-shap'd.

Decollatus-Decapituted. 


\section{TROCHUS-TOP-SHELL.}

Inimal-a Limax: Shell univalve, spiral, more or less conic; aperture somewhat angular or rounded, the upper side transverse and contracted; pillar placed obliquely.

THIS genus contains one hundred and twenty-nine species. The leading characteristic consists in its conica] shape, which prevails with few exceptions throughout the genus; some, however, are so nearly allied to the Turbo, that frequent mistakes arise in their classification.

Among those Trochi which have their pillar perforated or umbilicated, may be mentioned the T. Niloticus, T. maculatus, T. perspectivus, T. hybridus, and T. Pharaonis.

Though some of this genus have their surfaces almost smooth, yet the greater number are covered with knobs, spines, tuberculations, or undulations, of which the T. solaris and $\mathrm{T}$. imperialis, are striking examples: the former has its margin beset with long spines, placed at regular distances, resembling, when the shell is perfect, the rays of the sun as represented in carved work: it has also a most beautiful gold colour, which occasionally shines forth through the ochreous surface of the shell, and of course adds materially to the similitude. The T. imperialis is generally of a dull olive colour, but there is a rare variety of it which has a pinkish cast, and is known by the name of the Pink Sun: they are both from the South seas.

Of the imperforated species, the most characteristic are the $\mathrm{T}$. vestiarius, $\mathrm{T}$. labeo, and $\mathrm{T}$. tuber; the latter of which very much resembles a Turbo.

The T. iris, when uncoated, is celebrated for the splendid metallic lustre which illumines its surface, and for the 
vivid play of iridescent colours which it exhibits when held in different positions and lights.

The T. Cookii, from Cook's Bay, has its aperture closed with a horny lid or operculum, to secure the inhabitant when retired within its shell. This appendage is most frequent among the Univalve genera; it is affixed to the animal, which, as it retreats into the spiral whirls of its shell, draws the operculum in along with it, to a particular situation of the aperture, where, from the extreme accuracy of its adjustment, it perfectly closes the orifice, and thereby forms a complete barrier against any outward attacks.

The operculum varies in shape according to the form of the mouth it has to close : in some instances, it is elongated, and has a horny appearance; in others, it is circular, and of a very compact testaceous substance; some are perfectly smooth, and others strongly granulated.

The T. conchyliophorus is a very curious and remarkable species; for it is invariably covered with other substances, strongly adhering to the whirls of the shell.

Of this species there are two distinct varieties: one is called the Conchologist, from its being loaded with fragments of shells, and other testaceous substances; and the other is very properly named the Mineralogist, as its burthen consists of stones, earths, pebbles, ores, \&c. When the former variety is loaded with corals only, it is called the Zoologist or Coral-carrier. They are considered, when heavily laden, as rarities.

Some species of Trochi are much elongated, and greatly resemble screw or needle shells. Unlike the rest of the genus, they have an exserted pillar; and, when placed on their base, they fall on one side. The most prominent species are the T. telescopium and T. dolabratus.

The greater part of the Trochi present a brilliant mo- 
ther-of-pearl appearance when uncoated; others have only their aperture pearly or silvery; and a few exhibit a bronzelike hue.

There are several reverse varieties of Trochi: the principal are-T. perversus, T. undulatus, T. ventricosus, $T$. annulatus, and T.pusillus; the latter of which is found within larger shells, in the sands of India.

The T. flumineus is a river species, and the T. hortensis is an inhabitant of the gardens in warmer climates. The T. terrestris is also a land species, and frequents the mountains of Cumberland.

The following are the places which yield specimens of the Trochi: viz. Asia, Africa, America, Friendly Isles, New Zealand, Red Sea, Mediterranean, the European and British seas, \&c.

\section{TROCHUS-Top-Shell.}

\section{Division I.-Shell UMBILICATED, ERECT.}

FAMILY 1.-With the pillar and umbilicus smooth.

Niloticus-Large-marble.

Conus-Conic.

Spinosus-Thorny.

Jujubinus-Mottled.

Concavus-Concuve.

Vernalis-Green.

Conspersus-Poppy.

Ochroleucus-Whitish-brown.

Stellatus-Starred.

Spengleri-Spengler's.

Costatus-Ribbed.

Inæqualis-Unequal.

Regius-Royal.

Verrucosus-Warty.

Radiatus-Radiated.

Viridis-Green.
Fanulum-Pagoda.

Strigosus-Black-lipp'd.

Dubius-Doubtful.

Depressus-Depressed.

Lævis-Smooth.

Groenlandicus-Greenland.

*Magus-Tuberculated.

Variegatus-Variegated.

Afer-Grey-marble.

Muricatus-Prickly.

Roseus-Rose-colour' $d$.

*Patholatus-Tumid.

Scaber-Rough.

Quadratus-Square-spotted.

Croceus-Saffron-colour'd.

Varius-Vuried. 
*Obliquatus-Umbilicated.

Cinerarius-Ashy-colour'd.

Neritoideus-Reddish-colour'd.

Albidus-White.

Vittatus-Ribbon.

Divaricatus-Divaricated.

Fuscatus-Brown.

Umbilicaris-Obliquely-rayed.

Cinereus-Cinereous.

Fasciatus-Banded.

Planus-Flat.
Solaris-Sun.

Inermis-Short-spined.

Imperialis-Imperial.

Conchyliophorus-Carrier.

Tectum-Arch-lipp'd.

Pumilio-Dwarf.

*Terrestris-Land.

Bidens-Double-toot li' $d$.

Fragilis-Brittle.

Carinatus-Keeled.

Flumineus--River.

FAMILY 2.-With pillar toothed or plaited, and umbilicus smooth.

Maculatus-Spotted.

Alveare-Bee-hive.

Tentorium-Pavilion.

Agrestis-Rustic.

Niger-Black.
Cruciatus-Cross-rayed. Modulus-Keel-whirl'd.

Declivis-Egyptian.

Viridulus-Necklace-grained.

Perlatus-Pearly.

Family 3.-With pillar smooth, and umbilicus toothed or crenated.

Cylindraceus-Sub-conical. Carneus-Flesh-colour'd.

Areola-Red square-spotted.

FamiLy 4.-With pillar and umbilicus crenated.

Pharaonis-Sirawberry.

Guineensis-Guinea.

Corallinus-Coral-bead.

Urbanus-Purple-striped.

FamiL 5.-Shell depressed, with the umbilicus large, pervious, and crenated, in which the course of the whirls is strongly marked.

Perspectivus-Staircase.

Hybridus-Mongrel.

Perspectivunculus-Small-do. Stramineus-Straw-colour'd.

Infundibuliformis-Funnel- Indicus-Indian. formed.

Division II.-SHELL IMPERFORATE, ERECT.

FaMiLy 1.-With the pillar smooth.

Grandinatus-Studded. Tuber-Large-mottled. 
Melanastomus-Black-throated. Purpurascenis-Purple.

*Striatus-Striated.

Imbricatus-Imbricated.

*Minutus-Crimson-tip.

Cælatus-Scaly.

Punctulatus-Rose-colour' $d$.

Conulus-Conical.

*Zizyphinus-Livid.

Gibberosus-Olive-green.

*Papillosus-Granulated.

Virgatus-Rose-striped.

Cookii-Cook's.

Undatus-Undulated.

Iris-Iris.

Granatum-Tiger.

Elegans-Elegant.

Virgineus-Ringed.

Notatus-Marked.

Diaphanus-Thin.

*Ziczac-Ziczag.

Obtusus-Blunt.

Selectus-Red-and-white.

Crocatus-Saffron-colour'd.

Hortensis-Gurden.

Family 2.-With the pillar toothed.

Labeo-Double-lipp'd.

Asper-Rugged.

Quadricarinatus-Four-keeled.

Tessellatus-Tessellated.
Turbinatus-Turbinated.

Argyrostomus-Silier-mouth'd.

Merula-Chinese.

*Crassus-Heavy.

Americanus-American.

Family 3.-With the pillar twisted.

Mauritianus-Great-tooth'd. Pyramis-Obelisk.

Fenestratus-Small-tooth'd. Dentatus-Sugar-loaf.

FAMILY 4.- Shell convex, smooth, with a thick vitreous matter fwich covers the centre of the base.

Vestiarius-Flattened.

Division III.-ShELL TAPERING, with THE PILLAR EXSERTED, AND THE SHELL FALLING TO ONE SIDE WHEN

PLACED UPON ITS BASE.

Family 1.-With pillar twisted.

T'clescopium-Telescope. Terebellus-Little-augur.

Dolabratus-Zebra.

Family 2.-Pillar straight.

Minute Shells.

Punctatus-Dotted.

Striatellus-Violet-lipp'd. 
Reversed Shells.

Perversus-Reversed.

Pusillus-Minute.

Undulatus-Waived.
Ventricosus-Bellied.

Annulatus-Annulated.

Lunaris-Horn-colour'd.

\section{TURBO.-Wreath.}

Animal-a Limax: Shell univalve, spiral, solid: aperture contracted, orbicular, entire.

THERE are no less than one hundred and sixty-seven species of this beautiful genus; which are, for the most part, solid and ponderous shells, and many of them of a pearly nature when uncoated. They resemble the Trochus in form, but may easily be distinguished by their suborbicular aperture.

The first division has the pillar margin of the aperture dilated, and the pillar imperforate. Among the leading species may be enumerated the T. obtusatus, T. neritoides, and the $\mathrm{T}$. littoreus, or common periwinkle, a well known British shell: its fish, when boiled, is not unfrequently eaten. It is an inhabitant of most European shores; and it is said of them by sailors, that, if seen crawling high up the rocks, it is an indication of the approach of stormy weather; but if, on the contrary, they descend, a calm may be expected.

The next division consists of the solid and imperforated species: among the principal are the $\mathbf{T}$. petholatus, $\mathbf{T}$. chrysostomus, T. pagodus, T. calcar, and T. smaragdus; to which may be added, the T. cochlus, T. cornutus, T. marmoratus, and $\mathrm{T}$. olearius, the two latter of which sometimes attain a large size. 
The varieties of the $\mathrm{T}$. phasianus have been exceedingly rare:-there is no other species in this genus which presents so much beauty and diversity as the Pheasants. They are found at Van Dieman's Land, and other islands of the South Seas.

The next variation consists in the pillar of some species being perforated or umbilicated. The T.pica (as being the most known and easiest procured) will be the best to refer to as an example. The T. margaritaceus and the $\mathrm{T}$. argyrostomus also belong to this division.

Another division is composed of those species that are less solid, and cancellated. The wentle-trap (from the German, windle-treppe, or winding-staircase), one of the most beautiful as well as the rarest of the genus, will suffice to exhibit the peculiarities of this division. The true wentle-trap is a turbinated or spiral conical shell, varying in size from a quarter of an inch to upwards of two inches. The small and young shells are remarkably thin, brittle, and transparent, and generally possess more colour, (usually of a yellowish or pinkish white), than those farther advanced. The form is extremely elegant; its whirls, which are always gibbous or inflated, are beset, at regular distances, with numerous, elevated, carinated, suboblique longitudinal, continued ribs, evidently the remains of former mouths. In very young shells, the ribs are of a blueish semipellucid appearance, and have the interstices of a deep brown cast, occasioned, probably, by a thin epidermis, rather than a local colouring. There are said to be two varieties of the real wentle-trap, one having only eight whirls, and perforated; the other having ten whirls, and imperforated: they also inhabit different places; one, it is said, comes from Barbary, the other from Coromandel.

This species possesses a striking peculiarity, which con- 
sists in its being entirely destitute of a columella to connect its whirls; a circumstance so opposed to the regular structure of all other turbinated shells, must have, of course, created considerable doubt as to its classification, and some authors have even placed it among the serpulæ or wormshells.

The false wentle-trap, $\mathbf{T}$. clathrus, is a very common shell, and is easily distinguished from the true, by its being much more elongated and not umbilicated; the whirls also are more closely connected. There are three varieties of this species: one is pellucid, with very thin ribs; the other has its lip produced into a beak; and the third is spotted or dotted with brown. They are found in the European and Indian seas, in great abundance, from half an inch to two inches in length. It is said, that the ancients extracted a purple dye from the animal inhabiting these shells.

The shells of the ninth division are commonly called needles or screws; their shape is that of a well proportioned spire, with thirty or forty whirls gradually tapering or diminishing from the base to the apex, and there ending in a very acute point. The shells of this form are distinguished from the similar species among the Strombi and Buccina, by their having a circular or orbicular mouth.

Of the tapering or elongated Turbines may be mentioned the T. imbricatus, T. replicatus, T. acutangulus, T. duplicatus, and $\mathrm{T}$. terebra, which are the principals of the dirision.

The T. ulvæ is found adhering to the ulva lactuca. The T. perversus has its whirls contrary, and dwells among moss on old walls in most parts of Europe, as does also the T. muscorum. Among the fresh-water species the T. nautileus stands conspicuous; it is often affixed to plants in stagnant waters.

The species from the ocean are principally from the 
South seas; some are from the American and African oceans, and the Indian and Northern seas; and several species are to be met with in the Mediterranean, and European seas.

\section{TURBO-Wreath.}

Division I.-ShELl IMPERForATE, AND THE PILLAR-LIP FLAT.

FAMILY 1.-With a smooth exterior.

Obtusatus-Blunt.

Neritoides-Nerite-shaped.

Nicobaricus-Nicobar.

Nigerrimus-Black.
*Rudis-Pale-brown.

Punctatus-Punctured.

*Petræus-Small-rock.

*Fulgidus-Bronze-banded.

FAMILY 2.-With the exterior striated or ribbed.

*Littoreus-Periwinkle.

*Tenebrosus-Chocolate.
*Crassior-Coarse.

*Jugosus-Lineated.

Ethiops-Black and white.

DIVISION II.-SHELL IMPERFORATE, SOLID.

FANILY 1.-With a smooth exterior.

Personatus-Convex.

Petholatus-Serpent's-skin.
Cidaris-Turban.

Helicinus-Green and purple.

Imperialis-Imperial.

FAMILY 2.-With the exterior striated.

*Cimex-Bug.

${ }^{*}$ Calathiscus-Cancellated.

Cochlus-Cameleopard.

Smaragdus-Green.

FAMiLy 3.-With the exterior granulated. Castaneus-Chesnut. Crenulatus-Crenulated. Papyraceus-Paper.

Family 4.-With the exterior nodulous. Trochiformis-White-grain'd. Sarmaticus-Large-knobbed. Marmoratus-Marbled. Olearius-Large-keeled.

Coronatus-Coronated. 
Family 5.-With the exterior ribbed or grooved.

Canaliculatus-Grooved.

Setosus-Leopard.
Sparverius-Pearly-mouth'd.

Spenglerianus-Spengler's.

Family 6.-With the exterior somewhat spinous. Chrysostomus-Golden-month'd. Aculeatus-Painted. Tectum-persicum-Little pa- Stellatus-Spined. goda.

*Armatus-Armed.

Pagodus-Pagoda.

Rugosus-Rugged.

Calcar-Spur.

Stellaris-Starred.

Cornutus-Large-horned.

Radiatus-Radiated.

Moltkianus-Moltkian's.

Minute Shells.

* Semicostatus-Ribbed.

*Ruber-Red.

*Vitreus-Glassy.

*Punctura-Punctured.

*Arenarius-Sand.

*Unifasciatus-Banded.

*Nivosus-IVhite.

*Labiosus-Lipped.

*Ulvæ-Sea-weed.

*Ventrosus-Bellied.

* Subumbilicatus-Yellow.

*Cingillus-Girdled.

*Interruptus-Streaked.

*Semistriatus-Semi-striater?

Albulus-Pellucid.

\section{Division III.-Shell UMBILICATEd aNd SOLID.}

FAMIrY 1.-With the umbilicus toothed.

Pica-Magpie.

Nodulosus-Nodulous.

FAMILY 2.-The umbilicus without teeth.

Dentatus-Toothed.

Diadema-Diadem.

Muricatus-Prickly.

Undulatus-Waved.

*Auricularis-Eared.

Argyrostomus-Silver-mouti.

*Vinctus-Brown-banded.

Margaritaceus-Pearly.

*Quadrifasciatus-Four-banded. Porphyrites-Porphyry.

Sanguineus-Scarlet.

Mespilus-Medlar.

Atratus-Black-grained.

Granulatus-Granulated.

Anguis-Snake.

Cinereus-Ash-colour'd.

Torquatus-Thready. 
Division IV.-Shell DEPRESSED, FOLIATED, SPINOUS OR NODULOUS, AND UMBILICUS LARGE, PERVIOUS, AND ARMED WITHIN.

Delphinus-Dolphin. Exasperatus-Granulated. Distortus-Distorted.

\section{Division V.-CaNCELlated.}

FAMILY 1.-Umbilicated.

Scalaris-Wentle-trap.

Fanily 2.-Imperforated.

Principalis-Many-ribbed.

Clathrus-Latticed.

*Clathratulus-Little.
Lacteus-Milky.

Pulcher-Beautiful.

Ambiguus-Doubtful.

\section{Minute Shells.}

*Elegantissimus-Elegant. Simillimus-Similar.

*Parvus-Guernsey.

*Striatulus-Wrinkled.

*Reticulatus-Netted.

*Bryereus-Bryer's.
*Coniferus-Marginated.

*Denticulatus-Toothed.

*Arcuatus-Margined.

*Striatus-Striated.

* Costatus-Ribbed.

*Unicus-Convex.

Indistinctus_Indistinct.

Division VI.-SHELL WITH SUbCYLINDRICAL WHIRLS, SIMILAR TO THE LAST DIVISION, BUT NOT CANCELLATED.

Family 1.-Umbilicated.

Crenellus-Crenated. Limbatus-Shouldered.

*Thermalis-Fresh-water. Carinatus-Keeled.

Labeo-White-lipp'd. Ligatus-Ligature. Foliaceus-Leafy. Separatista-Three-keeled. Niveus-Snowy. Helicoides-Brown-ziczag.

Family 2.-Imperforate.

Crenatus-Crenated. Elegans-Elegant. Lincinus-Green-and-purple.

Lunulatus-Moon-spotted. 
DIVISIOX VII.-SHELL OBLONG, GLOSSY, BEAUTIFULLY MARKED WITH VARIOUS COLOURS, AND APERTURE SUBOVATE.

Phasianus-Pheasant. Inflatus-Infiated. *Pullus-Painted.

DIVISION VIII.-SHETL SUBCYLINDRIGAL, OBTUSF AT BOTH ENDS, AND APERTURE SEMI-OVATE.

FAMILY 1.-Aperture toothed.

Uva-Berry.

*Tridens-Three-tooth'd.

Mumia-Double-tooth'd.

*Juniperi-Juniper.

Alvearia-White-mouth'd.

*Muscorum-Moss.

Quinquedentatus-Five-tooth'd. *Sexdentatus-Six-tooth'd.

*Carychium-Minute-tooth'd.

Reversed Shells.

*Bidens-Double-tooth'd. *Nigricans-Blacl.

*Laminatus-Laminated. *Labiatus-Lipped.

*Biplicatus-Double-plaitcd. *Perversus-Reversed.

Corrugatus-Wrinkled. Quadridens-Four-tooth' $d^{2}$.

Vertigo-Vertigo.

FAMILX 2.-Aperture without teeth.

Cýlindrus-Cylindrical. Reflexus-Reflected.

Croceus-Orange. Auriscalpium-Ear-picker.

Sulcatus-Sulcated. *Politus-Polished.

Corneus-Horny. *Subulatus-Awl-shap'd.

Decussatus-Decussated.

\section{Division IX.-SHell TURRETED.}

Imbricatus-Imbricated.

Replicatus-Large.

Acutangulus-Sharp-angled.

*Duplicatus_Double-ribbed.

Torcularis-Brown-spotted.

Obsoletus-Obsolete.

*Exoletus-Ribbed.
*Terebra-Augur. Archimedis-Archimedes'. Variegatus-Variegated. *Ungulinus-Doubtful. Terebellum-Little. Annulatus-White.

Turris-thomæ-Tower. 
Division X.-Shell DEPRESSED.

*Nautileus-Nautilus.

*Cristatus-Small-crested.

*Depressus-Minute-flattish.
*Serpuloides-Serpula. Ludus-Green-spotted. Marginellus-Reflected-lip.

\section{HeliX.-Siatl or Spiral.}

Animal-a Limax: Shell univalve, spiral, subdiaphanous, brittle; aperture contracted, semilunar, or roundish.

THE one hundred and ninety-four species, which compose this genus, are principally land or fresh water shells, a few only being the produce of the ocean. They are usually of a delicate and brittle structure, and remarkable for their lightness; their general form resembles that of the common garden or hedge-snail, except in those species which are tapering or elongated.

The first division consists of the carinated Helices, and the more compressed or flattened species of the genus; which, from their shape, are commonly called Antique Lamps. The H. lapicida, H. marginata, and H. cicatricosa, have acute margins, and are characteristic of the carinated species. These shells were formerly supposed to have fallen in showers from the clouds.

Of the Antique Lamps, the H. lucerna, H. lampas, and H. carocolla, are illustrative specimens. The rarest species are the $H$. ringens, $H$. Gualteriana, and $H$. otis.

Some of the species of the third division are umbilicated, and are much more globose or inflated in their forms, as the H. pomatia; which snail is an inhabitant of the woods of Europe, and was introduced into England by Sir Kenelm Digby, for medical purposes. The aninal is used 
in many parts of Europe as an article of food during Lent, and was considered a luxury by the Romans. It is oviparous, and very tenacious of life; towards winter, it covers its aperture with a calcareous lid, resembling an operculum, and remains in a torpid state until the spring. The animal of the $H$. ampullacea in the sixth division grows to an immense size, and is also eaten; its eggs, which it deposits in clusters on the bark of trees, or rushes, $\& c$. have sometimes a pink tinge, but are generally dull white.

Of the species which compose the fourth division, may be adduced the $H$. dextra and the $H$. perversa (a synonym), which differ only in the direction of their whirls: they are both rare shells, and have their surfaces covered with a beautiful citron colour, variegated with green, and striped or banded with brown. The H. ovata and H. oblonga are both land shells; the eggs of the animals are perfectly elliptical, and nearly equal in size to those of the common sparrow. The animals of the H. ianthina and $\mathrm{H}$. globosa, forming the eighth division, have the property of emitting a phosphorescent light, and stain the hand of a purple colour, not easily removed; they are found in great numbers, floating on marine substances.

Amidst the endless variety of terrestrial shells, there is, perhaps, no species so well known as the $\mathrm{H}$. nemoralis or common garden snail; it is an inhabitant of European gardens and orchards, and very destructive to fruit and tender leaves. Its eggs are perfectly round, and about the size of small peas.

A very beautiful and rare species of the third division is the H. hæmastoma, which is admired for its elegant bandings and rose coloured lips. A black lipped variety of this shell has lately been discovered, which is also rather rare; the body of the shell being pink, forms a beautiful contrast with its jet lips. 
Of the turreted or tapering Helices may be particularized the $\mathrm{H}$. decollata and $\mathrm{H}$. columna.

The last division contains those species which have their apertures very large, exposing the whole of the interior of the shell, and bear in shape a strong resemblance to the genus Haliotis; of these the $\mathrm{H}$. haliotoidea may be adduced as an example.

Many of the Helices inhabit aquatic plants in standing waters, lakes, ponds, and ditches: others are found on trees and shrubs, and some harbour among rotten wood.

\section{HELIX-Snail.}

\section{Division I.-SHELl With A CARINATED MARGiN ON THE} BODY-WHIRL.

\section{Fanily 1.-Umbilicated and depressed.}

*Lapicida-Rock.

Marginata-Margined.

Cicatricosa-Reversed.

Albella-Whitish.

Albina-Minute-white.

*Rotundata-Small-radiated.

Lævipes-Reverse-whirl'd.
Exilis-White-striped.

*Cantiana-Kent.

*Rufescens-Reddish.

*Crenulata-Black-tipp'd.

Annulata-Ringed.

*Fontana-Fresh-water.

Turcica-Turkish.

\section{FAMILY 2.-Umbilicated and convex.}

Cornu-Large-horn.

Oculus-capri-Goat's-eye.

Involvulus-White-reflected.

Striatula-Striated.

Algira-Yellowish.

Leucas-Purple-lined.
Trochoides-Angular-mouth.

Incarnata-Flesh-colour'd.

Maculosa-Spotied.

Corrugata-Wrinkled.

Pellis-serpentis-Snake's-slin.

Avellana-Hazel-nut.

Family 3.-Imperforated and depressed.

Lampas-Orange-lip.

Carocolla-Large-brown.
Gualteriana-Gualter's.

Faba-Bean-shap'd. 
FAMILY 4.-Imperforated, and convex or ventricose.

- Vermiculata-Rough-dotted. Gothica-Doubtful.

Cornu-militare-Bugle-horn. Scabra-Rough.

FAMrLY 5.-Umbilicated, and aperture toothed.

Punctata-Punctured. Unidentata-One-toothed.

FaMiLy 6.-Imperforated and aperture toothed.

Sinuata-Sinuous.

Lucerna-Lamp.

Lychnucus-Top-shaped.
Cepa-Onion.

Nux-denticulata-Nut.

Verruca-Wart-lipped.

FAMILY 7.-Imperforate and convex, with the aperture toothed and turned upwards.

Ringens-Grinner.

FAMILY S.-Umbilicated and depressed, aperture ear-shaped, distorted, toothed, and sinuated, with a marginated lip.

Otis-Plaited.

DIVISION II.-SHELL DEPRESSED, AND WHIRL COILED HORIZONTALLY.

\section{Family 1.-Umbilicated.}

*Cornea-Horn.

* Contorta-Coiled.

Similis-Dotted.

*Alba-White.

*Spirorbis-Small-concave.

* Crystallina-Crystal.

Polygrata-Many-whirl'd. Cornu-arietis-Ram's-horn. Cornu-venatorium-Hunter's-horn.

FAMILY 2.-Imperforate and keeled.

*Planorbis--Notch-lipp'd. *Complanata-Flat-umbilicated.

*Vortex-Vortex.

Division III.-Shell with the APERTURE sub-lunate.

Family 1.-Umbilicated and depressed.

*Ericetorum-Heath.

* Strigata-Girdled.

Incisa-Slit-margin'd.

*Pisana-Pisa.

*Nitida-Pellucid.
*'Tenuis-Thin.

Cellaria-Cellar.

Obvoluta-Small white-lipp'd.

*Zonaria-Zoned.

Striata-Striated. 
Ungulina-Tawny-horn.

*Itala-Brown-banded.
Citrina-Citron.

Rapa-Single-band.

Minute Shells.

Minima-Minute.

Costata-Cross-ribled.

*Hispida-Hairy.

Pulchella-Striated.

Umbilicata-Umbilicated.

*Trochulus-Trochus-shaped.

*Aculeata-Prickly.

FaMily 2,-Umbilicated and sub-globular.

*Castanea-Chesnut.

Globulus-Globular.

Lucana-Transparent.

*Arbustorum-Single-streal.

Fruticum-Six-whirl'd.

Fulva-Amber.

Nemorensis-Polished.
Vittata-Ribbon.

Lusitanica-Lusitanian.

Hispana-Spanish.

Vitrea-Brittle.

*Pomatia-Edible.

Cincta-Red-banded.

Rosacea-Flesh.colour'd.

Extensa-Four-whirl'd.

Family 3.-Imperforate, and sub.globular.

Jamaicensis-Jamaica.

Rhodia-Rhodian.

Albolabris-White.lipped.

*Nemoralis-Varied.

Cartusiana-Carthusian.

*Lucorum-Brown-lipp'd.

*Grisea-Grey.
Sultana-Variegated.

Hæmastoma-Rose-lipp'd.

Lactea-Milky.

Picta-Painted.

Versicolor-Diversified.

Aperta-Gaping.

*Fusca-Brown.

Pellucida-Transparent.

FAMILY 4.-Imperforate, and spire rather produced.

*Vivipara-Viviparous.

Fasciata-Banded.
Dissimilis-Black-lippet.

Angularis-Angular.

FAMILY 5.-Umbilicated and spire produced.

Scalaris-Produced.

Division IV.-Shell ovate, oblong, ventricose, AND APERTURE OYATE.

Family 1,-Umbilicated.

Ovata-Oval.

Lutaria-Mud.
Oblonga-Oblong.

Flammea-Zebra. 
Kambeul-Kambeul.

Pileus-Red \& yellow-strip'd. Trifasciata-Three-banded.

Bontia-Brown-mouth'd.

Labiosa-Lipped.

Otaheitana-Otaheite.

Læva-Party-colour'd.
Dextra-Yellow.

Stagnorum-Barley-coriz.

* Obscura-Small-brown.

Lackhamensis-Lackham's.

Detrita-Smooth-rayed.

Guadaloupensis-Guadaloupe.

*Substriata-Substriated.

\section{Family 2.-Imperforate.}

Recta-Straight. Aspcra-Rough-striated. [cal.

Interrupta-Tessellated. *Sub-cylindrica-Sub-cylindri-

Papyracea-Fragile.

Arenaria-Minute-sand.

Pella-Small-red-brown.

Pupa-Little.

Barbara-Barbary.

Division V.-Shell ovate-oblong, With THE WHIRLS TRANSVERSELY KEELED AND CORONATED.

Amarula-Mitre.

DIVISION VI.-SHELL SUBGLOBULAR, VENTRICOSE, UMBILICATED, AND APERTURE OVATE-OBLONG.

Ampullacea-Smooth-girdled. Glauca-Greyish-brown.

Urceus-Cocoa $\bullet$ nut.

*Lacuna-Gutter-lipp'd.

DIVISION VII.-SHELL WITH THE WHIRLS LONGITUDINALLY ANGULATED ON BOTH SIDES.

Scarabæus-Cockchafer. Afra-African.

Division VIII.-SHELL UMBILICATED, ROUNDISH, OBTUSE, DIAPHANOUS, BRITTLE, AND APERTURE

SUB-TRIANGULAR.

Ianthina-Violet.

Globosa-Globose.

Division IX.-Shell CONICAL, OBTUSE, Distorted, THE SIDE OPPOSITE THE APERTURE GIBBOUS, APERTURE COMPRESSED.

Lyonetiana-Lyonet's. 
Division X.-Shell SUb-UMbilicated, PYRAMidal, AND SUMMIT OBTUSE.

Epistylium-Bee-hive.

Papilla-Nipple.

Division XI.-Shell ventricose, PELluCid, AND APERTURE OVATE.

FAMILY 1.-Imperforate.

*Stagnalis-Lake.

Fragilis-Brittle.

Inflata-Inflated.

*Palustris-Marsh.

Opaca-Opaque.

*Tentaculata-Dusky.

*Fossaria-Ditch.

*Lutea-Yellow.

Albicans-White.

Sicula_Sicilian.

*Putris-Thin-yellowish.

*Glutinosa-Membranous.

Peregra-Horny.

* Lævigata-Smooth fiesh-colour.

*Limosa-Rough.

Balthica-Baltic.

Truncatula-Truncated.

Neritoidea-Nerite-sliaped.

FAנILY 2.-Umbilicated.

Repanda-Ventricose.

*Canalis-Channelled.

*Auricularia-Eared.

\section{Division XI1.-TuRRETED.}

Fayily 1.-Apex truncated.

Consolidata-Flat-tipp'd. Truncata-Flag.

Decollata-Truncated. Calcaria-Challiy.

Contorta-plicata-Coiled-plaits.

\section{FAMILY 2.-Apex acute.}

Cuspidata-Pointed.

Plicaria-White-spotted.

Undulata-Waved.

Vibex-Red-marked.

Crenata-Crenated.

Fuscata-Brown-clouded.

*Peregrina-Eight-whirl'd.
Octona-Slender.

Columna-Columi.

Incumbens-Tawny-strip'd.

*Acuta-Double-banded.

Undata-Undulated.

Fluviatilis-River.

Turbinata-Turbinated.

Carinula-Brown-lin'd.

Division XIII.-ShEll DEPRESSED, SPIRE FLATTINH, APERTURE VERY LARGE, EXPOSING THE WHOLE INSIDE.

Perspicua-Large-mouth'd. Haliotoidea-Venus's-ear. 


\section{NERITA.-Nerite or Hoof-Shell.}

Animal-a Limax: Shell univalve, spiral, gibbous, flattish at bottom; aperture semiorbicular or semilunar; pillarlip transversely truncate, fattish.

THIS genus contains only sixty-seven species, and but few of any great beauty or rarity.

There is considerable variation in the form and markings of the Neritæ: some are spiral, with prominent whirls; others have their whirls partly or wholly concealed; some, again, are umbilicated, while others are perfectly entire and solid; and many have the umbilicus partially covered by a repand lip, or fissurated nodule.

The interior of the mouth and lips is, in many species, toothless; but, in others, both lips are beset with strong prominent and articulated teeth, often terminating in disjointed, elevated striæ, or protuberant granulations.

In most species, the back of the shell is covered with strong, elevated ribs, sometimes nodulous and imbricated; it is often only minutely striated, and has frequently a perfectly smooth surface and brilliant polish.

Of the umbilicated species may be particularized the $\mathrm{N}$. canrena, of which there are many beautiful varieties; and the N. cancellata, N. glaucina, N. vitellus, and N. mammilla; the common variety of the latter shell is white, having a porcelain appearance; but the rarer varieties incline to a brownish orange, having their lips surmounted with a black margin or border. The N. fulminea is marked with angular stripes, resembling forked lightning.

The next division of the Nerites consists of those which are imperforated and toothless, as the N. corona and N. fluviatilis; the former is often of a blackish colour, and has 
its whirls crowned with spines of an unequal length: the latter is an inhabitant of the rivers of Europe and Barbary; it is usually marked with scaly spots, and is sometimes rugged, streaked, or reticulated.

The species of the third division are distinguished from those of the preceding by having their lips toothed: the principal are the $\mathrm{N}$. pulligera, N. atrata, N. undulata, $\mathrm{N}$. larva, and $\mathrm{N}$. virginea, the latter of which is an inhabitant of the rivers of South America and India; like many other species of the Neritæ, it is toothed on the inner lip only. Its varieties are extremely beautiful, and are often called the Guinea-hen or Guinea-fowl Nerites, from the resemblance of its markings to the plumage of the bird so named.

The varieties of the N. polita are the most beautiful of this genus; they are smooth polished shells, and are generally clouded with green, having intermediate maculate bands of pale pink; but the most rare variety has three or four bright crimson bands on a dark mottled ground, running in a parallel direction with the convolutions of the shell. These shells are frequently worn as ornaments by the Indians.

Some species of this division are strongly ribbed or grooved, as the N. histrio, N. plicata, N. grossa, N. pica, and the N.chamæleon; which last is varied by alternate undulated black and white rays.

The N. turrita, from the Antilly Isles, and the N. aculeata, from India, are fresh-water species.

The different species of Neritæ are produced in the African, American, Indian, European, and Red seas; the Southern and Northern oceans, the Mauritius, the Cape of Good Hope, and New Zealand. 


\section{NERITA.-Nerite or Hoof-Shell.}

\section{Division I.-S̃Hell UMBILICATED.}

FAMILY 1.-With the umbilicus rather large, nearly pervious.

Vitellus-Clouded-yellow.

Punctata-Punctured.

Cruentata-Red-spotted.
Rugosa-Wrinkled.

Vittata-Ribbon.

*Pallidula-Pallid.

FaMILY 2.-With the umbilicus bifid.

*Canrena-Tabby-cat.

Cancellata-Latticed.
Sulcata-Grooved.

Spadicea-Chesnut.

Rufa-Reddish.

FAMILY 3.-With the umbilicus nearly closed by a callus, or by the inner lip.

*Glaucina-Livid. Albumen-Liver-coloured.

Orientalis-Eastern. Mammilla-Breast.

IIaroccana-Wave-striped. Papilla-Nipple.

Arachnoidea-Spider's-ueb. Melanostoma-Brown-pillar.

Ambigua-Ambiguous.

FAMILY 4.-With the umbilicus toothed.

Fulminea-Ziczag.

DIVISION 11.-SHELL IMPERFORATE AND TOOTHLESS.

FAMILY 1.-Spinous.

Corona-Crowned.

FAMILY 2.-Without spines.

Radula-Rough-ribbed.

Magdalena-Magdalen.

Cornea-Horny.

*Flnviatilis-River.
*Littoralis-Strand.

*Lacustris-Lake.

*Dubia-Black-mark.

*Marginata-Margined.

DIVISION III.-SHELL IMPERFORATE AND TOOTHED.

Fanul 1.-With the inner lip toothed.
Pulligera-Redlish.
Aculeata-Spinous. 
Pupa-Black-and-white. Bidens-Double-tooth'd. Flavescens-Yellowish. Viridis-Green. Virginea-Guinea-fowl.
Turrita-Turreted.

Piperina-Triangular-spotted.

Larva-Broad-band.

Ascensionis-Ascension.

Malaccensis-Malacca.

Hieroglyphica-Hieroglyphic.

FANILY 2.-With both lips toothed or crenated.

Polita-Smooth.

Lineata-Lined.

Peloronta-Bleeding-tooth. Versicolor-Many-colour'd.

Maxima-Great.

Pica-Magpie.

Histrio-Harlequin.

Stella_Star.

Tessellata-Tessellated.

FAMLY 3.-With the inner lip toothed and wrinkled.

Atrata-Smooth-black. Flammea-Flame.

Nigerrima-Black. Grossa-Red-thrush.

Antillarum-Wrinkle-lip. Undulata-Thin-wav'd.

Plicata-Horse-tooth. Quadricolor-Four-colour'd.

FamLy 4.-With the inner lip toothed and luberculated.

Albicilla-Pimple lip. Exuvia-Exuvia.

Fulgurans - Lightning.

FAMLy 5.-With the inner lip toothed, wrinkled, and tuberculated.

Plexa-Thrush.

Chamæleon-Chameleon.

Costata-Ribbed.

Undata-Waved.

\section{HALIOTIS,-SEA-Ear or EAR-ShelL.}

Animal-a Limax: Shell univalve, dilated, ear-shaped, with a longitudinal row of orifices along the surface; spire lateral, and nearly concealed.

OF this beautiful genus there are but twenty-two species; and their general form and appearance are so similar, that 
it often becomes a matter of difficulty to distinguish the one from the other. The form of all the Haliotides resembles the human ear, excepting one, which is called the $H$. asinina, or ass's ear, on account of its being much more elongated or distended than any of the other species.

There are three reasons which operate to create difficulty in the arrangement of the species of this genus:First, the outside of the shell is generally loaded with marine substances, or else is so much decayed or worn as not to offer a lineament of the original texture, thereby precluding all possibility of judging by the work or colour to what species it appertains. Secondly, as the interior of the Haliotides is enamelled with a magnificent surface of iridescent pearl, no great distinction can be made by a reference to that part of the shell. Thirdly, as the beauty of the shell is considerably increased by being wholly or partially uncoated and polished, it is customary to submit it to some such beautifying operation; which, however, with the surface at once removes all clue to the attainment of the specific character.

The exterior of the shell is generally composed of rugæ or tuberculations, over which pass approximate elevated striæ. In some species, foliations supply the place of tuberculations, as in the H. Midæ or Midas' ear; the outside of which is wrinkled, and of a dusky white hue; but the inside is most beautifully iridescent. It is often eight or nine inches long.

The back of almost the whole of the Haliotides is furnished with a row of orifices near the margin; varying in number from eight to thirty-eight; of these from three to seven are generally open, and the rest perfectly closed. There are, however, three exceptions to this general character; for the H. imperforata, H. impertusa, and H. dubia are entirely void of any orifices. The former, which 
has an ovate form, with an exserted spire and prickly ribs, is a rare shell.

The Haliotis tuberculata is found on the British coasts. The H. parva is remarkable for its red or scarlet colour, and for having but one large elevated rib or angle on its back. The H. bistriata is peculiar for having a succession of double elevated striæ, placed in a transverse direction on the back. The H. pulcherrima is a beautiful and rare shell from the South Seas.

The H. iris, (from New Zealand), is celebrated for its bright iridescent colours, which are finely contrasted with a green and gold bronze-like lustre. The H. gigantea, from New Holland, sometimes exceeds a foot in length.

The Haliotides are found on the shores of Europe, Africa, and India; where, like the limpets, they adhere to the rocks, from which they are with difficulty removed.

\section{HALIOTIS-Sea.Ear.}

\section{Division I.-SHELl PERFORATED.}

Fasil y 1.-Roundish or ovate.

Midæ-Midas'-Ear.

Pulcherrima-Beautiful.

Virginea-Iridescent.

*Tuberculata-Common.

Striata-Wrinkled.

Bistriata-Double-lined.

Varia-Rough-striated.

Marmorata-Marbled.

Glabra-Smooth-mottled.
Australis-Rough-plaited.

Gigantea-Gigantic.

Iris-Iris.

Cracherodii-Cracherode's.

Ovina-Chesnut-marble.

Parva-Small-orange.

Rufescens-Magnificent.

Splendens-Splendid.

Corrugata-Corrugated.

Family 2.-Oblong.

Asinina-Ass's-ear.

Division II.-Shell iMPERforate.

Imperforata-Carinated. Impertusa-Imperforate.

Dubia-Doubtful. 


\section{UNIVALVES.}

II. WITHOUT A REGULAR SPIRE.

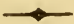

\section{PATELLA.-Limpet or Dish-Shell.}

Animal-a Limax: Shell univalve, subconic, shaped like a bason, without a spire.

THIS genus contains one hundred and six species. They are very similar in form, which, with a few exceptions, approximates to that of a cone, with its apex a little blunted. But, with regard to the colours and workings, they differ exceedingly; some being perfectly smooth, whilst others are strongly granulated and spinous; and many are deeply striated or covered with elevated tuberculated rays.

Of the limpets which are very entire, and not pointed at the tip or crown, those most worthy of notice are the $\mathrm{P}$. afra, P. areolata, P. flammea, P. Indica, and P. testudinaria; the latter is rather a rare species, and generally has its interior of a silvery hue. The P. compressa is remarkable for its narrow and lengthened form, which gives it the appearance of having been squeezed or pinched.

The $\mathrm{P}$. umbellata is one of the rarities of the genus; it sometimes grows to a large size; it is a flat, broad, expanding shell, of a blueish white colour, having its interior of a glossy yellowish or brownish cast, and the tip generally 
of a beautiful orange colour; the margin is often circularly scalloped.

Those species which are more compressed, and have their margins angularly or irregularly toothed, form the second division: as the P. laciniosa, P. saccharina, P. granularis, P. granatina, \&c. The P. vulgata, or common limpet, is found in great abundance on the British shores.

The third division of the Patella includes the perforated species; the principal are the P. Græca, P. nimbosa, P. Caffia, P. perforata, and P. macroschisma; the latter, when in fine preservation, is considered a rarity; it grows to a considerable size, and is found at Japan.

The next division comprehends the species which are cap-shaped, and have a recurved tip. Of these the $P$. Ungarica is the most remarkable; it is a beautiful shell, and from its similarity of shape is called the Fool's Cap. The exterior is usually of a pale fawn colour, and the outer margin is bordered with a fine bristly epidermis; when the interior is of a very bright pink colour, this limpet is considered more valuable.

The P. lutea has some resemblance to an Haliotis, but the flatness and ear-shaped form of the latter genus is a sufficient distinction. The P. pectinata is covered with spines, and the P. perversa is remarkable for having its clown recurved, and turned towards the hind part of the animal.

The species of the sixth division are entire, and furnished with an internal lip, which is strikingly observable in the P. equestris and P. Sinensis; some of them are rough and scaly, whilst others are perfectly smooth and polished; they are known by the name of Cup-and-saucer Limpets.

The species of the seventh division are chambered or vaulted, and have the appearance of a slipper; such are the P. porcellana, P. fornicata, and P. aculeata. 
The Patellæ are usually found adhering by their base to rocks, stones, fuci, and other marine substances, from which they are with much difficulty removed. They inhabit the Indian, Southern, European, Northern, and Mediterranean seas; the American and Indian islands; the Atlantic, and the shores of China, Greenland, and Iceland.

The Patellæ derive their name from their resemblance to a little dish or bason reversed.

\section{PATELLA-Limpet.}

Division I.-Shell with the summit obtuse, and the margin entire ${ }^{*}$

*Pellucida-Pellucid.

${ }^{*}$ Lævis_Smooth.

Radians-Grey-mottled.

Rota-Roundish.

Testudinaria-Tortoise-shell.

*Clealandi-Clealand's.

Testudinalis-Small-tortoise-sh.

Compressa-Flat-sided.

Mytiliformis-Muscle.

Afra-African.

Rustica-Narrow ribbed.

Jamaicensis-Jamaica.

Stellifera-Starred.

Fusca-Sugar-loaf.

Areolata-Pyramidal.
Flammea-Agate.

Indica-Indian.

Vitellina-Yellow.

Lævigata-White-tipp'd.

Surinamensis-Surinan.

Punctulata-Dotted.

Notata-Wheat-sheaf.

Cruciata-White-cross.

Reticulata-Reticulated.

Cæca-White-border'd.

Virginea-Purple-rayed.

Tessellata-Tessellated.

Fulva-Orange-tawny.

Ambigua-White-duck's-bill.

Umbellata-Parasol.

Division II.-Shell with the margin angular, or irregularly toothed.

Laciniosa-White-eyed.

Plicata-Plaited.

Monopis-Chesnut-streaked.

Saccharina-Star.

Angulosa-Angular.

Repanda-Small-sun.

Tenuis-Thin-amber.
Margaritacea-Great-sun.

Barbara-Toothed.

Cypria-White-ribbed.

Oculus-capri-Goat's-eye.

Pentagona-Five-angled.

Granularis-White-grained.

Granatina-Garnet. 
Chlorosticta-Pigeon's-throat. Ulyssiponensis-Buckler.

Tigrina-Tiger.

Ornata-Adorned.

Melanogramma-Black-ribbed.

Ferruginea-Rusty.

Crenata-Little-grey.

Sanguinolenta-Rose-streaked.
Radiata-Radiated.

Lugubris-Black.

Vulgata-Common.

Cœrulea-Blue.

Tuberculata-White-pimpled.

Cochlear-Horse-shoe.

Division III.-Shell with the summit perforated.

Noachina-Perforated.

Pustula-Doubtful.

Græca-Cancellated.

Atricapilla-Black-ring.

Nodosa-Tuberculated.

Perforata-Partridge.

Caffra-African.
Pileolus-Open-cap.

Scutellum-Scutcheon.

Picta-Painted.

Nimbosa-Scaly-ribbed.

Nubecula-Variegated.

Porpliyrozonias-Porphyry.

Macroschisma-Key-hole.

Division IV.- Shell with the summit pointed and recurved.

*Ungarica-Fool's-cap.

* Militaris-Hooked.

*Antiquata-Antiquated.

Cochleata_White-ridged.

Calyptra-Helmet.

*Intorta-Inclining.

Cassida-Lentil-seed.

Tranquebarica-Brilliant.
Mammillaris-Nipple.

Leucopleura-Small-rayed.

Tricarinata-Three-keeled.

Pectinata-Spined.

F usco-lutea-Yellowish-brown.

Lutea-Yellow.

Perversa-Reverse-tipp'd.

Lacustris-Lake.

\section{Oblonga-Oblong.}

Division V.-Shell with a marginal fissure.

*Fissura-Slit.

Incisa-Reticulated-slit.

Fissurata-Rose-colour' $d$.

Division VI. - Shell with an internal appendage at the summit.

Equestris-Cup-\&-saucer.

Neptuni-Neptune's-cap.

Tectum-Chinese-roof.
* Sinensis-Chinese-bonnet.

Auriculata-Ear-shap'd.

Duplicata-Double.

Drvision VII.-Shell with an internal transverse partition. Trochiformis-Trochus-shap'd. Trochoides-Wave-ribbed. 
Neritoidea-Chambered.

Porcellana-Brown-spot.

Fornicata-Slipper.
Aculeata-Spiny-ribbed.

Goreensis-Sandal.

Crepidula-Transparent-white.

\section{DENTALIUM-Tooth or TUSK-ShelL.}

Animal-a Terebella: Shell univalve, tubular, straight, or slightly curved, with an undivided cavity open at both ends.

OF this singular genus there are but fifteen species; they are very similar in form, and resemble an elephant's tusk in miniature.

They differ principally in magnitude, and in the number of ribs and grooves with which some of the species are marked; a trifling distinction may also be made with regard to the degree of curvature which many of them possess.

One of the largest and most valuable species is the $D$. elephantinum; it is often three or four inches long, slightly curved, and has generally ten strong, elevated ribs, which are encircled by dark green bands on a greenish ground; it inhabits the Indian and European seas.

The D. rectum, though nearly allied to the D. elephantinum, is a straight shell, and therefore easily distinguished from it. It is also adorned with doubled or tripled longitudinal striæ, which at the same time are encircled with annular ones. The $\mathrm{D}$. fasciatum is a small species, finely striated, and encircled with four or five brown bands on a greyish ground.

Some species are striated annularly: such are the D. politum, (which is finely pointed, solid, and often of a rosy or pinkish colour), and the D. eburneum. 
Other species are smooth, or covered with striæ, so minute that they cannot be discovered without the aid of a magnifying glass. Of these, the D. pellucidum is an example; it is of a horny or pale honey colour, very narrow and thin, and does not effervesce in acids; it is an inhabitant of the Northern seas, and about two inches and a quarter long. The D. entalis, which is an inhabitant of the Indian and European shores, is generally an inch and a half long, and of a reddish or pale yellow colour, and the tip is often tinted with orange or pink.

The D. minutum inhabits the Mediterranean; it is a round, straightish, smooth shell, and so very minute as scarcely to be discernible by the naked eye; it resembles a small bristle, or one of the spines of an echinus.

The D. imperforatum (from Sandwich and its neighbourhood) is also a minute species, and is by no means common.

The recent species are mostly from the Indian and European oceans; though some few are from the Mediterranean and Northern seas, and one species inhabits the shores of Africa.

\section{DENTALIUM-Tooth-Shell.}

FaniLy 1.-With longitudinal ribs.

Rectum-Straight.

Elephantinum-Elephant's.

Aprinum-White-ribbed.

*Imperforatum-Minute-truncated.

FaMiLy 2.-With annular stria.

Politum-Ring-striated. Eburneum-Smooth-ivory.

*Trachea-Minute-windpipe.

FaMily 3.-Smooth.

*Entalis-Common.

*Gadus-Hake's.

Corneum-Horn-colour'd.

*Minutum-Minute.

Pellucidum-Pellucid. 


\section{SERPULA-WorM-ShELL.}

Animal-a Terebella: Shell univalve, tubular, generally adhering to other substances: often separated internally by divisions at uncertain distances.

THE genus Serpula contains forty species; their form (with few exceptions) is exceedingly irregular. They are generally found in groups or clusters, adhering to other substances, such as rocks, stones, roots of trees, sides of ships, zoophytes, sertulariæ, fuci, shells, corals, \&c. They are invariably tubular, and present themselves sometimes isolated, either straight or twisted, but more frequently in clusters, consisting of many hundred spiral and twisted tubes, curiously interwoven with each other.

Of the species which are isolated and spiral, may be instanced the S. spirillum, S. spirorbis, and S. afra; which have their whirls nearly contiguous, and resemble the Helices.

To this same class belongs the well-known but rare shell, the Watering-pot Serpula, (S. aquaria). Its larger end is closed by a convex disk, with numerous small perforations, and generally a longitudinal one in the middle, the whole encircled by a dilated margin of elegant papyraceous tubes, resembling a beautifully plaited ruff or frill; the smaller end is open. It is found in the Indian ocean, and seldom exceeds five inches in length.

The S. gigantea is about an inch in diameter, and sometimes exceeds half a foot in length. The S. lumbricalis is a flexuous shell, with a spiral acute tip, and very much resembles a cork-screw.

One of the remarkable species of this genus is the $S$. anguina, which has a slit or long-jointed cleft along the 
spiral convolutions of its shell. The S. muricata has its shell beset with a succession of spines or prickles: it is usually of a rosy or pink colour, and sometimes has its aperture margined.

The S. cornu-copiæ, or horn of plenty, is, in all probability, only a dropped Helix nemoralis, or common garden snail, and of course not belonging to this genus. The S. denticulata is sometimes found in the Lepas tintinnabulum; and the S. granulata adheres to the roots of the fucus digitatus; the $\mathrm{S}$. retorta is retort shaped; the latter is scarce. The S. incurvata partially resembles the Nautilus semilituus, but it wants the internal concamerated structure.

The colours of the Serpulæ are various; the most general, however, are brown, purple, yellow, tawny, pink, and white, sometimes a little greenish.

The Indian, African, American, and Northern oceans supply many species; as also do the European, Mediterranean, Adriatic, and Red seas.

\section{SERPULA-Worm-Shell.}

Division I. - Attached to other substances. Spirillum-Minute Spiral. Glomerata-Glomerated. Triquetra-Three-sided. Conica-Conical.

*Intricata-Intricate.

*Corrugata-Wrinkled. Contortuplicata-Twisted.

Goreensis-Goree.
*Vermicularis-Round.

*Tubularia-Tubular.

Denticulata-Toothed.

Ocrea-Boot-shaped.

Gigantea-Great.

Minute Shells.

Stellaris-Rayed pin's-head. Granulata-Grained. Planorbis-Flat.

Minuta-Minute. Cancellata-Grooved.

Spirorbis-Tapering.

*Heterostropha-Reversed.

Carinata-Keeled.

*I ucida-Shining.

Vitrea-Glossy. 
Drvision II.-Detached.

*Semilunum-Small-reed.

Incurvata-Incurved.

Cereolus-Bougie.

Nebulosa-Clouded tawny.

Lumbricalis-Cork-screw.

Arenaria-Sandy.

Afra-Smooth-brown.

Volvox-Caterpillar.
Anguina-Serpent. Muricata-Prickly.

Annularis-Ringed snake.

Retorta-Retort-shap'd.

Cornu-copiæ-Cornucopia.

Decussata-Decussated.

Proboscidea-Proboscis.

Protensa-Lengthened.

Division III.-With radiated border and perforated disk. Aquaria-Watering-pot.

\section{TEREDO.-SHIP-WORM.}

Animal-a Terebella, with two calcareous hemispherical valves cut off before, and two lanceolate ones: Shell tapering, flexuous, and capable of penetrating wood.

THERE are but four species of this genus: the first is the T. navalis, or common ship worm; it is very thin, cylindrical, and smooth, and is more or less twisted, and rather obtuse or blunt at the tip; it varies in length from four to six inches. This worm was originally imported from India, it has the faculty of penetrating the stoutest oaken planks of ships' sides, and effects as much destruction in the water as the termes or white ant on land.

The T. utriculus is also cylindrical, undulate, and solid; it is found in wood that has lain some time under water. It is white, subpellucid, very much bent, and gradually tapering, with an oval aperture, divided in the middle by a partition. Its length is about seven inches.

The third species is the T. clava, which is found in the 
seminal vessels of the xilosteum granatum; one end is clavate, the other incurved, narrower, obtuse, and perforated in the middle: the shell is rough, and brownish on the outside, but within it is smooth, and more or less flexuous. It is nearly two inches long, but not half an inch wide. The fourth is the $\mathrm{T}$. gigantea, which is remarkable for having its interior separated by imperforated convex and concave divisions, making the shell appear as if it consisted of numerous united tubes. The smaller end of this shell is also peculiar for being terminated by two distinct or separate small tubular pipes, which are jointed in the same manner as the main stem from which they spring; the shell, in this state, resembles a two-pronged fork. It is an inhabitant of the Mediterranean and Indian seas, and is often found concealed under the sands; it sometimes attains the extraordinary size of three feet.

\section{TEREDO-Ship Worm:}

Navalis - Ship.

Utriculus-Timber.

Clava-Club-shaped.

Gigantea-Gigantic.

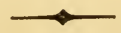

SABELLA.--SABELLA.

Animal-a Nereis, with a ringent mouth, and two thicker tentacula behind the head: Shell tubular, composed of particles of sand, broken shells, and vegetable substances, united to a membrane by a glutinous cement.

THIS very extraordinary genus contains no less than twenty-five species. The membrane which composes the 
basis of these animals is covered with various fragments and particles of different marine and vegetable productions.

The $\mathbf{S}$. vegetabilis and $\mathbf{S}$. arundinacea are covered with fragments of twigs, the bark of stems or reeds, and broken pieces of tellina cornea. The S. ammoniata is coated with fragments of the cornu-ammonis.

The covering of the S. Indica is composed of capillary sub-cylindrical agglutinated crystals of quartz; and that of the $\mathbf{S}$. clavata of various sized stones.

Some of the species, as the S. scruposa, S. chrysodon, \&c. are detached; whereas the $S$. scabra is affixed by the base.

The S. alveolata has numerous parallel tubes, communicating by an aperture, forming in the mass the appearance of honey-combs. It is an inhabitant of the European coasts, and covers the rocks for a considerable space, and is easily broken under the feet. The tubes are straightish, and from two to three inches long. The S. rectangula is one of the largest of the genus, and often measures nine inches in length.

There are no less than fourteen or fifteen species which inhabit rivers and fresh waters; and most of them are from the waters of Thuringia and Belgium, where they are affixed to stones, \&c. The other species are from the Indian, American, Northern, and European seas.

\section{SABELLA-Sabella.}

FamiLy 1.-Composed of grains of sand, stones, or shells.

Scruposa-White sandy.

Scabra-Rough.

Alveolata-Honeycomb.

Chrysodon-Pebble.

Belgica-Tubular.

Rectangula-Rectangular.

Capensis-Cape.
Nigra-Black.

Stagnalis-River.

Conica-Conic.

Uncinata-Hooked.

Sabulosa-Gravel.

Ammoniata-Ammonites.

Helicina-Helix. 


\section{UNIVALVES. - SABELLA.}

Dimidiata-Divided.

Fixa-Stony.

Clavata-Club-shap'd.
Marsupialis-Sooty.

Norwegica-Norway.

Lumbricalis-Coarse.

Indica-Indian.

Family 2.-Composed of vegetable substances.

Vegetabilis-Vegetable.

Corticalis-Bark.
Arundinacea-Reed.

Aculeata-Twig.

THE END. 



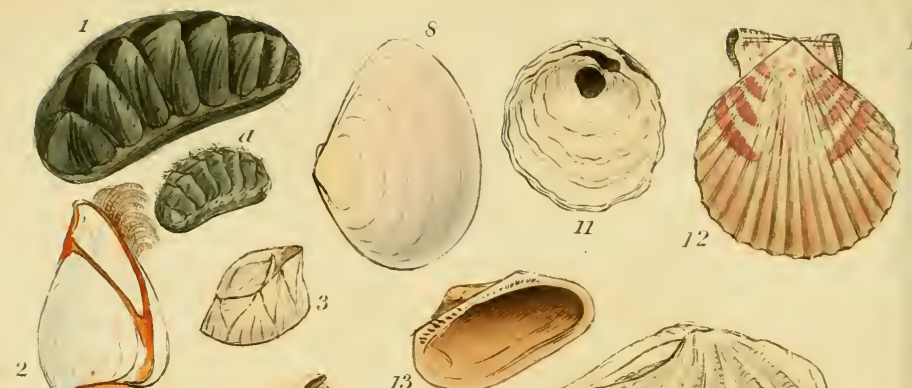
EXPLANATION OF THE PLATES.

PLATE I.

Fig.

1 Chiton Squamosus.... Scaly Chiton.

a Chiton Fascicularis .... Banded Chiton.

2 Lepas Anatifera....... Duck Barnacle.

3 Lepas Balanoides...... Smooth Acorn Shell.

4 Pholas Dactylus...... Prickly Piercer.

5 Mya Truncata ....... Abrupt Gaper.

6 Tellina Ferroensis ..... Brindled Tellen.

7 Pinna Pectinata...... Muricated Pinna.

8 Solen Sanguinolentus .. Red Solen.

9 Solen Legumen ....... Pease-cod Razor Sheath.

10 Mytilus Modiolus...... Tulip Muscle.

11 Anomia Ephippium.... Common English Anomia.

12 Ostrea Opercularis..... Common English Pecten.

13 Arca Noæ.......... Noah's Ark.

14 Chama Gigas ........ Furbelowed Clam.

15 Spondylus Gædaropus . Thorny Oyster.

16 Venus Chione........ Smooth Brown Venus.

17 Donax Denticulata.... Toothed Wedge Shell.

18 Mactra Stultorum..... Common English Mactra.

10 Cardium Edule ....... Common Eatabie Cockle. 


\section{PLATE II.}

Fig.

20 Argonauta Argo ...... Paper Nautilus.

21 Nautilus Pompilius .... Chambered Nautilus.

22 Nautilus Spirula...... Spiral, or Crozier-headed Nautilus.

23 Conus Virgo, or Tessel- Mosaic, or Tessellated Pavelatus

24 Conus Ebræus ........ Hebrew Cone.

25 Conus Textile....... Embroidered, or Cloth of Gold Cone.

26 Cypræa Arabica...... Nutmeg Cowry.

27 Cypræa Moneta...... Trussed-fowl, or Black-amoor's-tooth Cowry.

28 Cypræa Mus......... Mouse Cowry.

29 Bulla Terebellum..... Auger, or Borer Bulla.

30 Bulla Naucum ....... White Bulla, or Dipper.

31 Bulla Lignaria ........ Wood-grain Bulla.

32 Voluta Utriculus ...... Còmmon Olive.

33 Voluta Musica....... Music Volute.

34 Voluta Episcopalis..... Bishop's Mitre.

35 Voluta Persicula ...... 'Pigmy Volute.

36 Voluta Tornatilis...... Mouse-ear Volute. 

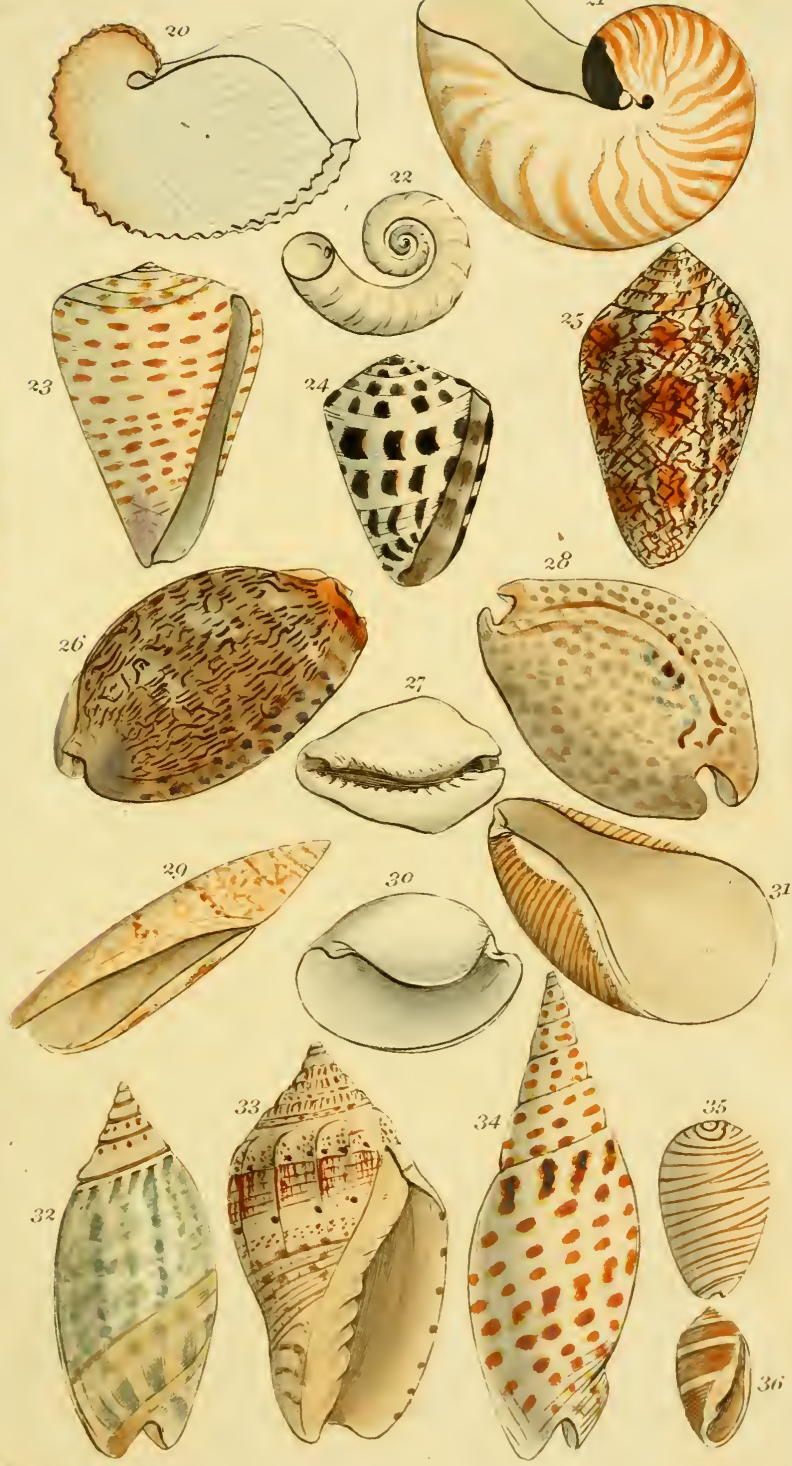




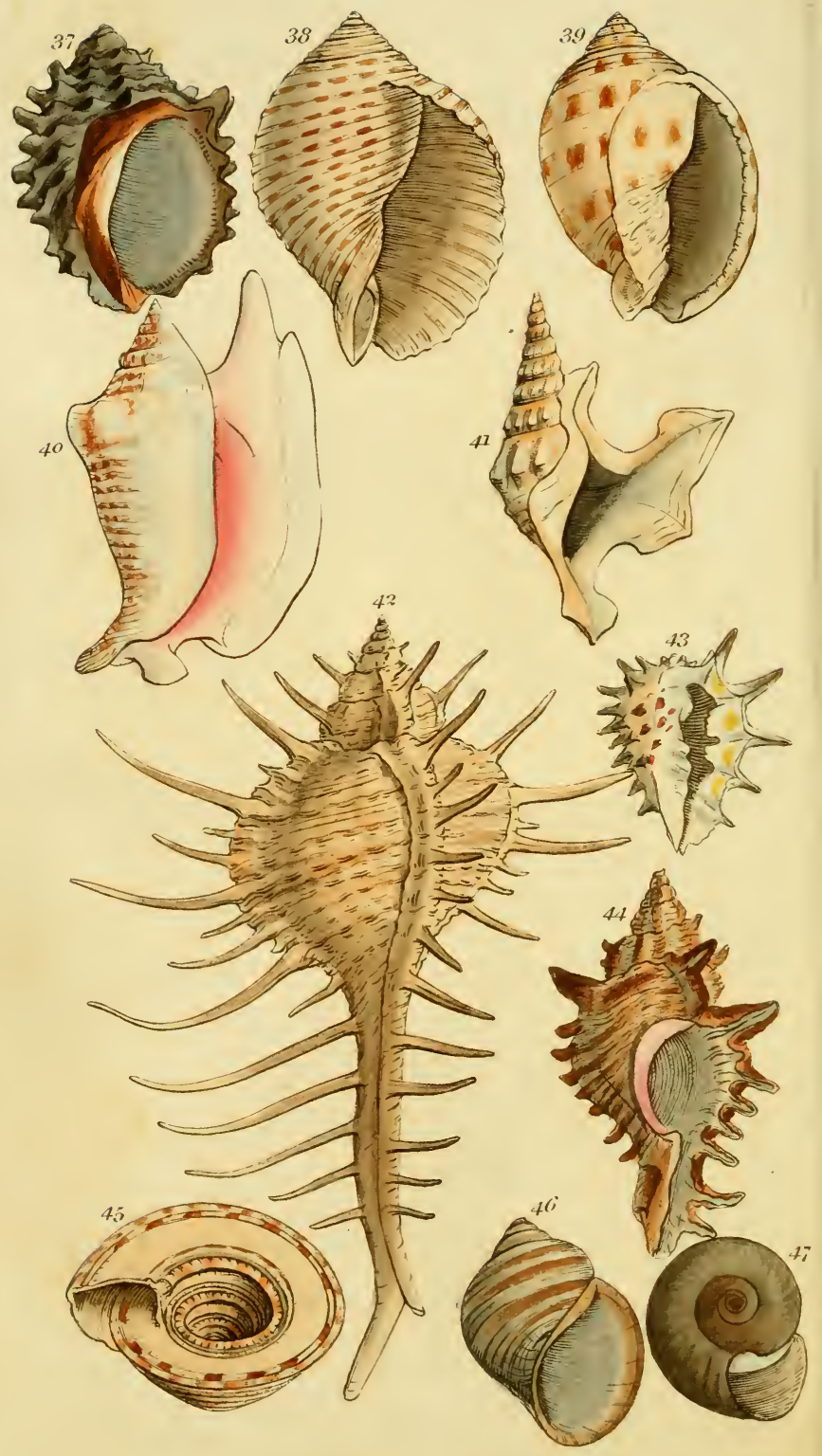




\section{PLATE III.}

Fig.

37 Buccinum Patulum ... Common, or Wide-mouthed Scoop.

38 Buccinum Dolium ..... Ribbed Tun.

39 Buccinum Areola..... Draft-board Helmet.

40 Strombus Auris-Dianæ - Ass's-ear Alatus

$\overline{41}$ Strombus Pes-Pelicani.. Pelican's-foot Alatus.

42 Murex Tribulus ....... Thorny Woodcock.

43 Murex Neritoideus..... Mulberry.

44 Murex Ramosus...... Aculeated Triplex.

45 Trochus Perspectivus... Staircase Trochus.

46 Helix Ampullacea.... Apple Snail.

47 Helix Cornea ........ Ram's-horn Snail. 
PLATE IV.

Fig.

48 Turbo Bidens....... Two-toothed Turbo.

49 Turbo Petholatus ...... Ribband Turbo.

50 Nerita Virginea ....... Guinea-hen Nerite.

51 Nerita Plicata........ Plaited Nerite.

52 Haliotis Tuberculata ... Common Ear Shell.

53 Haliotis Asinina...... Ass's-ear Shell.

54 Haliotis Tuberculata ... Outside view of fig. 52.

55 Patella Perforata ...... Perforated Limpet.

56 Patella Vulgata....... Common Limpet.

57 Patella Fissura ....... Cracked Limpet.

58 Patella Sinensis ...... Chinese-bonnet Limpet.

59 Patella Equestris ..... Cup-and-saucer Limpet.

60 Dentalium Striatum .... Striated Tooth Shell.

61 Serpula Aquaria ...... Watering-pot Serpula.

62 Teredo Navalis....... Common Ship Worm.

63 Sabella Belgica....... Granulated Sabella. 

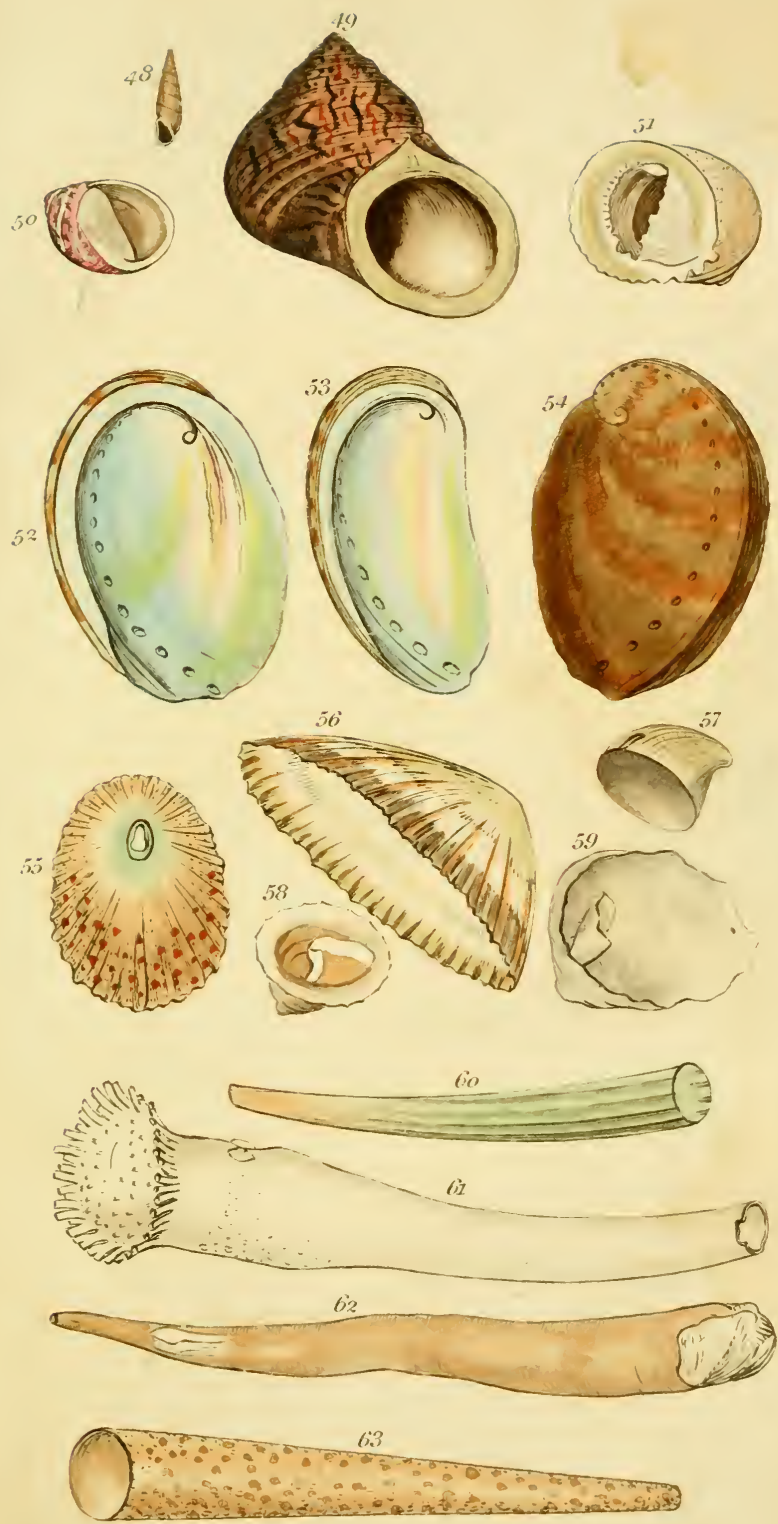



\section{PLATE V.}

Sheuing the Hinges of Bivalves, and other Peculiarities.

Fig.

1 Internal view of the Donax Scortum, shewing the hinge.

2 Internal view of the Solen Siliqua, shewing the hinge.

3 Internal view of the Solen Vespertinus, shewing the hinge.

4 Internal view of the Ostrea Isognomon, shewing the hinge.

5 Internal view of the Pholas Dactylus, shewing the teeth.

6 Internal view of the Pinna Pectinata.

7 Internal view of the Mactra Stultorum, shewing the hinge.

8 Internal view of the Mytilus Hirundo.

9 Internal view of the Mya Aurita, shewing the hinge.

10 Trochus Conchyliophorus, shewing its singular propensity of collecting and affixing shells to itself.

11 Variety of the above, sometimes called the Mineralogist, because it collects stones. 


\section{PLATE VI.}

Fig.

1 Mytilus Edulis, shewing the beard or byssus.

2 Teredo Navalis, shewing the shells imbedded in the wood, which they have perforated.

3 Variety of the Murex Lotorium, shewing its hairy epidermis.

4 Helix Ampullacea, partially covered with its epidermis.

5 Variety of Ostrea Varia, shewing a Serpula adhering to it.

6 Venus Meretrix, shewing the anterior slope.

7 Arca Glycymeris, shewing the inside and the hinge.

8 Cardium Lineatum, shewing the inside and the hinge.

9 Internal view of the Anomia Sella, (in a young state), shewing the triangular hinge.

10 Internal view of the Tellina Virgata, shewing the hinge.

11 Internal view of the Spondylus Gædaropus shewing the hinge.

12 Internal view of the Chama Cordata, shewing the linge.

13 A group of Lepas Tintinnabulum.

14 A group of Lepas Anatifera, shewing the peduncles and tentacula. 


\section{WORKS ON MINERALOGY AND CONCIIOLOGY,}

BY

J. MAWE, No. 149, Strand,

PUBLISHED BY

MESSR. LONGMAN \& Co. PATERNOSTER-ROW.

Lessons on Mineralogy and Geologv, coloured Frontispiece, shewing the mode of Working the Gold and Diamond Mines in Brazil, also a Lead Mine at Matlock; and plate of twenty-eight various Minerals; also a plate shewing Rocks of the Primitive, Secondary, and Floetz Formations. 9th edition, Price $6 s .6 d$. This work is written entirely from practice, for beginners; it noints out the easiest mode of becoming acquainted with Minerals, studiously avoiding technical phrases, and unnecessary comment.

New Descriptive Catalogue of Minerals, with Diagrams of their Simple Forms from Dr. Clarke's Syllabus, 8th edit. Price 7 s. This Catalogue, by pointing out the Distinctive Characters of Minerals, and associating them in a natural order, is particularly adapted for the Arrangement of Collections.

Instructions for the Management of the Blowpipe, the application of the Acids and Chemical Tests, with descriptions of their Use in the examination of Minerals, and an Appendix from Berzelius, 4 th edit. price $4 s$. with colored Frontispiece.

Treatise on Dianonds and Precious Stones, containing their History, Natural and Commercial, with Frontispiece of colored Stones, and several plates explaining the modes of cutting and polishing; also a Scale of the size and price of Brilliants, \&c. The method of distinguishing the Gem from Composition. Plate of the large Diamonds in Europe; plates of the forms of rough Diamonds ; and an historical account of their Discovery in Brazil ; also a commercial account of every variety of Gem denominated Precious Stones, or used in ornamental Jewelry. Price $15 \mathrm{~s}$. 


\section{WORKS ON MINERALOGY AND GEOLOGY.}

Travels in BraziL through the Gold and Diamond Districts, brought down to the present time, describing the methods of working the Mines, extracting the Gold with Mercury, also the Natural Products, Agriculture, Commerce, Population, Manners and Customs, with a Map of the Author's journey from Rio de Janiero to Tejuco, the Capital of the Diamond territories. A new edition, price 18s., with numerous colored plates.- “ I cannot close the account of Brazil, without a strong recommendation of the Travels in the interior of that Country, with a particular account of the Gold and Diamond District, by Mr. J. Mawe, Mineralogist, illustrated with colored plates." Dibdin.

Aiatrur Lapidary's Guide, containing Instructions for Cutting, Polishing and Slitting Hard Stones of every description. Price $1 s .6 d$.

LAPIDARIES' APPARATUs complete, with Jim-Peg or gauge for fucet work. This apparatus will perform every variety of work, and is applicable to polish Shells and soft Substances. Price, including Diamond and Materials, $£ 10$. This apparatus may be worked on a parlour table.

MaWE'S LINN.EAN System of CONChology, in 8vo, describing the Orders, Genera, and Species of Shells, arranged into Divisions and Families, with a plate to each Genus (36). Price 1 l. 1 s. plain, or 2l. 12s. $6 d$. most beautifully coloured after Nature.

Ma WE'S Wodarch's Introduction to the Study of Conchologx, $8 \mathrm{vo}$., describing the characters of the Orders, Genera, and Species of Shells; with an extensive Catalogue of names under each Genus, to which is added the best mode of Collecting, Cleaning, and Preserving Shells. 7 plates, $9 s$. plain; or $14 s$. colored.

Shell Collector's Pllot, or Voyager's Companion, with a colored Frontispiece, and plate of Insects. This Work is particularly adapted for Voyagers in general, pointing out the places where the best Shells were obtained during a Voyage of Discovery round the World; alsu the best methods of preserving Insects, Birds, \&c. 4 th edit. Price 4 s.

an Illustrated Introduction to Lamarck's Conchology, being a literal Translation of the Descriptions of the recent and Fossil genera, accompanied by 'Twenty-two highly finished Lithographic plates, By F. A. Crouch, F. L.S. Price $1 l .11 s$. $6 d$. plain ; or $3 l .3 s$. beautifully colored.

An Epltome of Lamarck's Arrangement of Testaceq, with I1lustrative Observations, by C. Du Bois, F. L. S. Price 14s. This is a most excellent work, and comprises the essential parts of Lamarck's Seven Volumes. 


\section{Collections of ftimcrals, kne.}

TU facilitate the acquiring a knowledge of Minerals, Collections are formed consisting of the Metals, the Earths, and the Rocks, arranged after Werner, in Cabinets, with Catalogues, at the following prices :-

100 Small specimens of Metals, Earths, and Rocks $\ldots \ldots \ldots £ 2 \quad 2 \quad 0$

100 Ditto, with Glass Blowpipe, Magnet, Tubes, Forceps,

Borax, and Box of Fragments for Experiments..... $212 \quad 6$

190 Varieties, larger size, arranged with Mawe's New De-

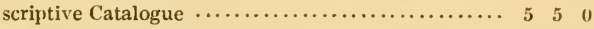

230 Ditto, larger, and more select Specimens, with ditto .. $1010 \quad 10$

Collections containing a greater number of specimens, Twenty Guineas and upwards, as they are more select or numerous.

Geological Collections from Freyberg, after Werner, colasisting of specimens illustrative of the various Formations, from Two to Ten Guineas.

Minerals of every Description, and at various Prices.

The most interesting Specimens and rare Crystallizations.

Glass Blow-pipes, 1s. 6d. each. Fragments for the Blow-pipe or Microscope, 1s. to 5s. per box, Agate and Steel Mortars, Platina Spoons, Forceps, Hammers, of various sizes, Electrometers, Knives, Glass Tubes, and whatever is requisite to the Mineralogist and Geologist.

Fluor Spar, Strontian, Barytes, Asbestos, Molybdena, Uranium, Cobalt, Platina, \&c., for Chemical purposes.

Models of the most celebrated Dianonds in Europe, with a Description of their Weight and Value.

MoDELS of Crystals, in Wood, after Hauy, Janeson, and Mawe's Catalogue.

Diamonds Crystallized; also Salphires, Rubies, Emeralds, and Topases.

Yellow Crystal, Cairn Gorm, Agates, Jasper, Camelians, Onyxes, \&c.

Rough Dranowds and Diamond Powder for Engravers and Lapidaries.

$\Lambda$ great variety of Seal Stones.

Seals elegantly Engraved, by the best artists.

\section{Collections of \$bells.}

Collections shewing the genera, from Five Guineus to Ten or Twenty, according to the number and quality of the Specimens.

The finest Collection in Europe, (on sale), price inarked on cach shell.

I great variety from $6 \mathrm{~d}$. to $1 \mathrm{~s}$. each.

I magnificent Collection of C'orals. 


\section{LIST OF USEFUL ARTICLES}

Compostna

\section{A Cibmícal Apparatus.}

FOR THE ANALYSIS \& EXAMINATION OF MINERALS.

BY J. MAW E, 149, S T R A N D.

I M PRov E D brass Blowpipe, Steel Mortar, Electrometer, Magnetic Needle: Platina Spoon, Forceps, Wire, and Foil; Spirit-lamp, Wax Candle, Charcoal, Magnet, Brass Forceps, Evaporating Capsule Glasses and Frame; Knife, with Magnet, Forceps, \& File; Metallic Rods for precipitating Metals, Glass Tubes, Litmus Paper, Magnifying Glass, Hammer, Crucible, Touchstone, and Minerals for Experiments.

TESTS,

Contained in bottles with ground stoppers.

itrate of Silver. Carbonate of Soda. Nitrate of Barytes. Prussiate of Potass. Oxalic Acid. Tincture of Galls.

Carbonate of Ammonia. Super Acetate of Lead.

ACIDS,

In bottles with ground stoppers and caps, to prevent the fumes oscaping. Nitric, engraved $N$. with hlue stopper.

Sulphuric, $\cdots$ s. S. $\ldots \ldots \ldots \ldots \ldots$.

Muriatic, ..... M. M.............

FLUXES.

Glass Borax. Phosphoric Acid. Cream of Tartar.

METALLIC RODS.

Copper. Iron. Zinc. Tin.

Black Marble Vases, Obelisks, Inkstands, and Tables of the most classical forms and devices.

Italian Alabaster Vases, Figures, and Models, copied from the Antique, of the most exquisite Workmanship.

DIAMOND reduced to the finest powder, and applied to Razor Strops, will be found to supersede any thing yet discovered for sharpening Razors and fine Cutlery; it is formed into a paste, and sold at $2 s_{\text {. or }}$ 3s. (dd. per box. 





